\title{
Introduction 1943
}

\section{Turning points}

By 1943 the prospect of Allied victory began to look increasingly likely. Daily life in Paris was still exceedingly difficult for the most part, but morale had improved. It helped that food shortages were interspersed with short-lived periods of relative abundance. Madeleine writes almost double the number of words in 1943 than she had in the previous, bleaker years. She wrote more about her social life. Theatre, opera and classical music concerts were regularly noted down. Notes about the fiction she was reading are also plentiful. The prospect of an end to the Occupation also meant that Madeleine appeared to be less reluctant to refer to its political and military context. In 1943, we see that Madeleine's renewed hope of a return home cause her to contemplate the scholarly and career possibilities which might await her. These musings give a fascinating insight into the struggle she shared with other educated women of the 1940s to pursue her ambitions in the face of societal and cultural pressure to settle for a more traditional role as wife and mother. Madeleine's listings of her reading choices are important in this regard because many of these choices, from Marie Bashkirtseff's posthumously published diary to the novels of the first generation of post-first-wave feminism writers like Winifred Holtby, Rosamond Lehmann and Madeleine Bourdouxhe, reflected her own dilemma between an academic career and a stay-at-home existence - two divergent paths which she struggled in her diary to reconcile.

Madeleine's year began with snow, severe cold and ailments. On the 5th of January she wrote that she was 'dizzy' with hunger. The diary narrative continued to focus on getting enough food to eat and how to cook and prepare it so that it was palatable. At home, in her apartment, the cold was such that the windows were iced up on the inside of the panes and she could not sleep at night. The snow and ice and lack of adequate footwear made it difficult to get around Paris on foot which, given the limited availability of public transport, many Parisians were forced to do. However, unlike the previous two years, the winter gloom was quick to lift. The early spring, which Madeleine described with keenly observed descriptions of a variety of flora in bloom, ushered in an optimistic, brighter tone to her entries. She talked of the possibility of liberation by 
way of scattered references to the progress of the war, Charles de Gaulle's optimistic speeches and to her home country of Yorkshire to which she 'returns' by way of the pastoral evocations of Winifred Holtby. After reading South Riding, set in North Yorkshire, she wrote 'Je belong au Yorkshire'. Home, in 1943, felt closer than it had done for the whole of the previous three years.

By the summer of 1943, military setbacks for the German army in Italy and on the Eastern Front had caused French civilians to speculate - with some confidence - about the imminence of an Allied assault on mainland Europe. There was also evidence that civilian resistance was becoming more established. Certainly, the military wing of the Resistance had, by 1943, emerged as an organised force boosted by large numbers of young men avoiding compulsory work service in Germany: the 'Service du travail obligatoire' or STO (Jackson, 2001: 480). But many ordinary citizens were becoming actively involved in 'soft' resistance. Julian Jackson describes this as 'individual acts of protest like tearing down posters or scrawling graffiti' (Jackson, 2001: 476). For Madeleine, this involved giving up her bed for the night to shelter Allied airmen shot down over Paris and giving English lessons to individuals like Hélène Barland, the document counterfeiter associated with the key Resistance network Turma Vengeance.

Madeleine's brighter mood reflected the improvement in living conditions and her financial circumstances. She had regular and secure employment at France's national library, and more disposable income meant more opportunities to go out and enjoy herself. Incidences of depression and homesickness were fewer. She had got better at coping with the day-to-day grind by 1943 and, over the course of the summer, appeared to switch her attention to how she might cope with life after the Liberation. The Occupation had delayed the completion of her doctorate on which she depended for a future academic career, and a return home to her parents on whom she was still financially reliant was not an appealing prospect. The Occupation had been an ordeal but an empowering ordeal. The struggle to survive and the freedoms she had enjoyed had, she felt, made it impossible to return to the life she had shared with her parents in York before the war. By the summer of 1943, Madeleine was 26 years of age and objectives of both marriage and a career seemed to be slipping away. There are a number of ponderous and sometimes anxious passages in which she contemplates positive and negative scenarios of what life might be like back home after the war. These passages displace, for a brief time, the documentary style of the diary which had dominated the narrative from October 1940. They are prompted by speculative reverie and, on occasion, the 'unreality' of anxiety dreams relating to the future which awaits her.

Dissatisfaction about the possibility of limited opportunities back home comes through very clearly in what she was writing in August: 'A girl stays at home - well, yes, perhaps but not when she has had to earn her crust all alone for three years dictated to by necessity and with only herself to keep her going. The feelings Madeleine was expressing mirrored those of many women 
towards the end of the war. Hannah Diamond describes how women had been forced to take on greater responsibilities during the Occupation. In many cases they took on key responsibilities at home and, on occasion, in the workplace, and many were reluctant to go back to their previous lives after the personal and financial autonomy they had enjoyed (Diamond, 1999: 207). Feminism might have taken a backseat to the fight against fascism in the 1930s but it had not disappeared. Women's liberation had continued to evolve on a number of fronts during the Occupation in spite of discriminatory, revisionist legislation which excluded married women from the civil service, made abortion a capital offence and divorce more difficult to obtain. Indeed, Sylvie Chaperon specifically refers to this wartime generation of young, educated women as providing the political, intellectual energy for the revival of organised feminist protest in the 1960s and 1970s. These women, were, she wrote, women who had fought through adversity to succeed (Chaperon, 2001: 99-116). ${ }^{341}$

It is in 1943 that it becomes clear that Madeleine was selecting novels to read because they mirrored the challenges and dilemmas she faced at this particular point in her life. Over the summer she reads a number of novels by British 'middlebrow' women writers of whom Winifred Holtby and Rosamond Lehmann featured most prominently. A key recurring theme of these novels, written by university women of the inter-war in the immediate wake of first-wave feminism, was the schism between what their female protagonists wanted from life and what society wanted them to settle for. The novels examined the struggle of (mainly) middle-class women to realise their raised expectations when societal and cultural pressures to conform to traditional gender norms were still very present and persuasive. The novels are not a confident validation of a woman's right to pursue her own unfettered course oblivious of social convention and responsibility. Indeed, they present young women as conflicted and frustrated, facing choices which make them vulnerable to isolation and social stigma. A good number of these novels show that 'sex success', the term given by Nicole Humble in her study of the middlebrow novel to women's attainment of social mobility through marriage, still presents women's best chance of improving their lot in life. ${ }^{342}$

Madeleine's anxiety returns time and again to focus on the apparent choice she felt she faced between marriage and a career. Like the middlebrow heroine, she was captivated by the excitement of independent bohemian living and the 'intellectual life'. But she also shared her fear of being 'left on the shelf', of being alienated and cast out for pursuing ambitions of benefit only to herself. If anything, it would appear that the novels, which did not offer happy solutions

${ }^{341}$ Muel-Dreyfus (2001) and Miranda Pollard (1998) both give insightful accounts of the experience of women under Vichy.

${ }^{342}$ Humble (2001) makes this connection between the post-first-wave feminist generation and the inter-war middlebrow novel. 
encapsulating the career and marriage Madeleine hoped for, did not help. After she has read them, she writes 'depressed' after their titles. However, it is interesting that she battled her fears by articulating her own narratives in which she could have everything she wanted but feared she might be denied. She describes her ideal home, complete with diagram. In it, she is an academic, with an academic husband and four young children. She and her husband have study rooms and there are bedrooms and other facilities for their four children. For Madeleine it would seem that 'sex-success' went in hand-in-hand with career success. It was a very modern outlook. We see glimpses elsewhere in 1943 that Madeleine understood feminist discourse, which was still very much in circulation during the Occupation. She was very impressed by Madeleine Bourdouxhe's novel, A la recherche de Marie (1943), recognising through Marie, the novel's Sorbonne graduate heroine, Bourdouxhe's message that if women surrender to societal and cultural expectation then they surrender the possibility of freedom. 'One can polish oneself by using others but one must watch not to wear oneself away. We must not polish ourselves so that the image of the other becomes engraved in us', she writes on August 13th, 'I am getting carried away this evening but it is something I hold very dear and I will fight for that and my freedom all my life. ${ }^{343}$

In conclusion, 1943 is the year when Madeleine begins to see the possibility of an end to an existence which for her, and for most French people, had caused their lives to stagnate and had stymied their personal and professional plans. But alongside an understandable excitement and anticipation of an end to the Occupation came anxiety of what the end of the war would mean for the future. Anxiety about what lay ahead would not have been unique to Madeleine. Many people had endured familial rupture through bereavement, forced labour in Germany or imprisonment of loved ones. Reconciliation with former lives would prove emotionally and practically impossible for many.

${ }^{343}$ For more on how Madeleine contemplated her post-war future, the gender expectations to which she was subject and the place of reading in these reflections, see Michallat's 2017 article 'Writing a Scholarly Occupation: Student women diarists (1940-1944)', Essays in French Literature \& Culture. 


\section{3}

\section{Friday 1 January}

Went to Lardy's. Everyone charming. Françoise's 8th birthday.

\section{Saturday 2 Jan}

Wrote to Jean: "My dear Jean. By the looks of things we have arrived at a bit of a dead end. I can see no way out other than us finishing it. So, adieu. Madeleine. ps. I'd be grateful if you could give me back my "Merlin L'Enchanteur" and my wine allowance card." He'll have that Monday morning. I'd love to see his face. Went to Mme Faure's for $2 \mathrm{pm}$. Had ice cream at Weber's. Card from Mme Desportes inviting me over but received it too late. Pneu from Aunt. Read "Via Mala". ${ }^{344}$ Very good. Went to bed at $4 \mathrm{am}$. Confession but think that I will need to confess again. Card from Colette Brand and Paulette Trois-Gros.

\section{Sunday 3 Jan}

Mass. Went to Aunt's. Aimée and Huguette came to lunch. I hate it at Aunt's but at the moment she couldn't be nicer. Had a note from Colette.

\section{Monday 4 Jan}

Office. (Started the year off well by not doing my gym but I am tired out by all these late nights). Pauphilet. Saw Jacqueline Eichorn. Returned "Deidre of the Sorrows" to Hélène Berr. Went to pay the electricity but it was shut. Went to Mme Desportes. Went to Colette's but she wasn't there. Went to Dilys's. Bronchitis and perhaps the right lung has got something wrong with it? Diphtheria and

${ }^{344}$ A thriller by Swiss writer John Knittel (1891-1970). It was published in 1934. See the Swiss Review for more on Knittel:

http://www.revue.ch/en/editions/2015/01/detail/news/detail/News/heturned-the-world-into-a-stage-for-his-novels/

Page 174: View of Val-de-Grâce from 320 rue St Jacques in winter. Copyright Delphine Biechler, licensed under CC BY-NC 4.0. 
'flu in this district. Wrote to: Chateau, Corbeil, Troyes, Dédé, Colette Brand, Paulette Trois-Gros, Zinser, Zéau, Mlle Bruard (for money), Jeanne Semaille, Godfather, Granny, Vendryès, Jacqueline Piatier. Sent a note to Ruth Camp. It is starting to get colder. I am going to have to put on stockings and wear a wool pull-over under my make-do blazer. Thirsty, pain in the small of my back, stomach ache. Am a bit all over the place just lately - it's all the different food when I am flying all over the place as well as the irregular times. Colette brought "Merlin l'Enchanteur" (2 volumes) (Edgar Quinet). They don't look that good. The lift still doesn't work.

\section{Tuesday 5 Jan}

Snowed. Was at the office all day. Gilberte was transferred to Mlle Murray. Had lunch sat next to Michael who was very intrigued by who had managed to get me to go out with them and reiterated his profession of everlasting love. Paid the electricity. Went to the Hôtel de Ville for the posters. Lesson with Dick. Paid. Feet hurt so much because the soles are made of wood with straw uppers and the snow is so thick. Letter and card from Hélène Koch. Wrote to Mlle Koch. Am so hungry. I was forced to eat some horrible but expensive stuff at 5 pm because I am dizzy with hunger.

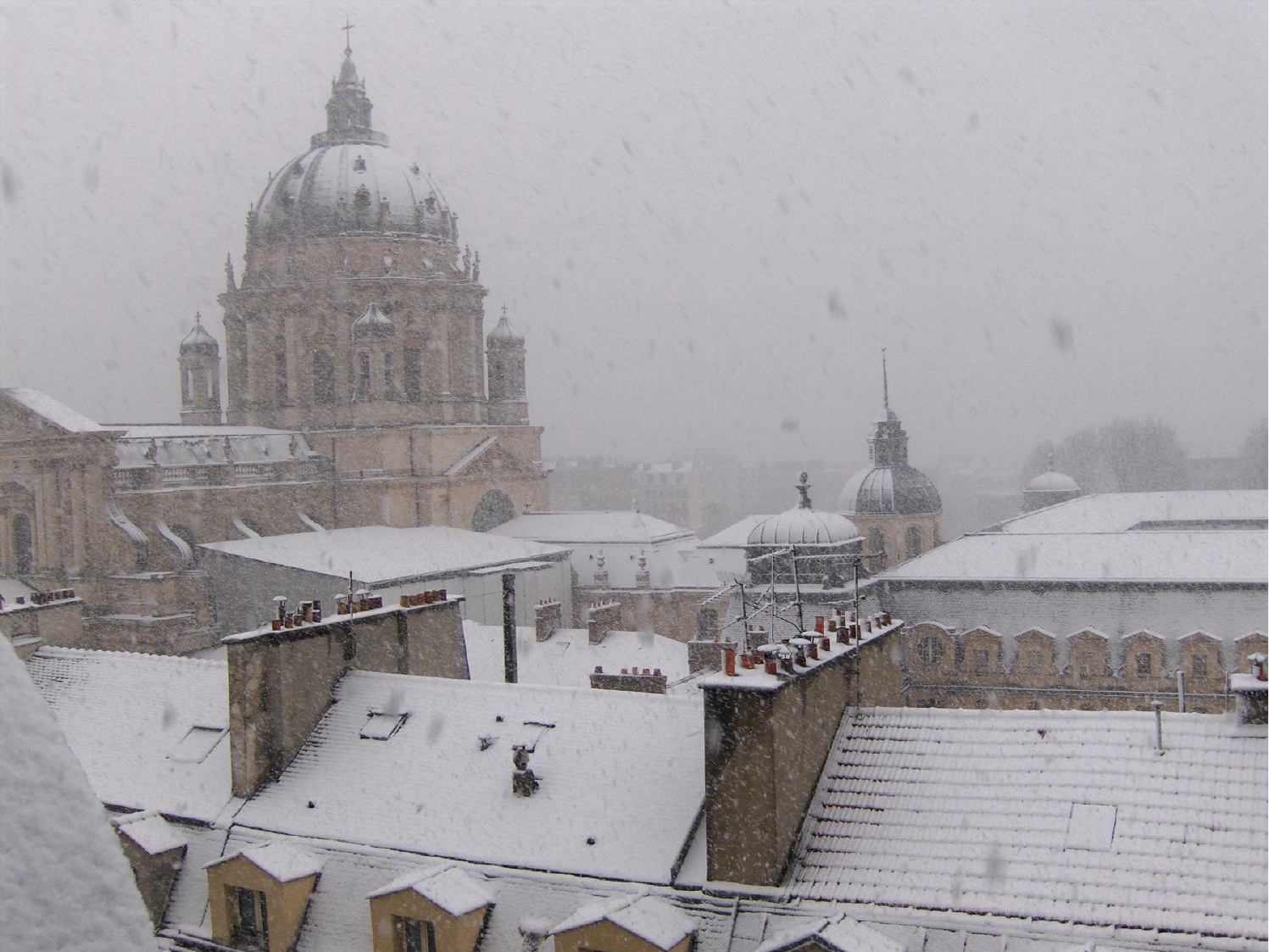




\section{Wednesday 6 Jan}

Office. Breton. Irish 2-5 pm. Tea with Mrs Desportes but a horrible friend of hers was there. "La Source" 7 pm. Hélène. Restaurant. (v.good) "Les Affaires sont les Affaires" (Ch. Vanel). ${ }^{345}$ Could have been a good film.

\section{Thursday 7 Jan}

Office all day. Lesson with Gilberte. Had flageolet beans. Jean returned book. The Pole brought his medicine book to type.

\section{Friday 8 Jan}

Welsh. Irish. Vendryès. Office. Dick. Started translation. Hot water so had a wash. $1 \mathrm{pm}-2^{\circ} \mathrm{C} \ldots$

\section{Saturday 9 Jan}

It is freezing cold. Ice on the inside of the windows. Office. Marc Chesneau visited on behalf of the City of Paris. I was introduced to the poet Paul Fort. ${ }^{346}$ Little 70 year old man very full of himself. Good paper. Not impressed by the poems. Saw Jean but slipped off before he could follow me. He sat behind me listening to the whole thing much to Mme [. . .]'s great amusement. Ate roasted beetroot. We are seeing coins in our change again. Before they gave out stamps or metro tickets. Letter from Corbeil. M. Blum died 23 February 1942!! Confession. Typed the translation. Very windy - being here is like being in a boat in open sea, everything vibrates, sings and sways in the howling wind.

\section{Sunday 10 Jan}

3 am. Pouring rain woke me up. There was a fire behind the Val-de-Grâce. This morning there were long icicles on the iron rail. Ice outside and fog. Mass. C. Villeparisis but Aunt, Yo didn't come - Granny is upset and uptight. - kind.

${ }^{345}$ Directed by Jean Dréville and starring Charles Vanel, the film was an adaptation of Mirabeau's play.

346 Paul Fort (1872-1960), 'French Poet and innovator of literary experiments, usually associated with the Symbolist movement. For more on Fort, see: https://www.britannica.com/biography/Paul-Fort 
Mme Dumont, Gérard, Jacques Deschamps, all came to eat the Epiphany cake. $M$ Lebère made a brief appearance to say that he would not be coming because his wife had come back. Maurice Roche is very ill. Stepfather and Granny are devastated. They would have so loved him to marry Yolande. Came back on the $7.10 \mathrm{pm}$ train. Here 8.50. Fog. Typed translation.

\section{Monday 11 Jan}

Office. The weather is mild as if it's April. Daffodil bulbs sprouting in the window 'garden'!!! Very happy. Typed translation. Took a few posters. Pauphilet lecture. Request for jacket rejected because only for those doing greasy, oily work. Asked for shoe and slipper tickets. Found out about the going rate for medical translations - 14 francs per 100 words of French!!! Telephoned Aunt. Typed translation until $5 \mathrm{am}$.

\section{Tuesday 12 Jan}

Slept from 5-8.30 am!! 40 minutes late to the office!! Went to see Mlle Horn and came down from 750 to 650 francs for the thesis! Went to the Maison des Lettres for interview. Will I get a job? At the very least I should get note taking and translation corrections. Lesson with Dick. Card from Cyla. Wrote to Voirin. Not tired but will go to bed early.

\section{Wednesday 13 Jan}

Office. Welsh. Bachellery - only me and Mme (Maggy) Desportes and I was late too because I had taken posters to St Louis and to Louis-le-Grand. Tea with Mme Desportes. "Jérôme $60^{\circ}$ Latitude de Nord" (Maurice Bedel) ${ }^{347}$ Bought "Sylvie et le Fantôme (Adam). ${ }^{348}$ (I?)

\section{Thursday 14 Jan}

Office all day. Kort insufferable. Went to Hôtel de Ville. Wrote to Aunt. Ruth came but I soon sent her packing. She wanted "Chut Chick" and I haven't got it.

\footnotetext{
${ }^{347}$ Maurice Bedel (1883-1954). The novel was awarded the Prix Goncourt in 1927.

348 A play by Alfred Adam (1908-1982). The play was staged at André Barsacq's théâtre de l'Atelier in Paris in 1943. For more on Barsacq's theatre under the Occupation see section on it in Limore Yagil (2015) Au nom de lart, 1933-1945: Exils, solidarities et engagements (Paris: Fayard).
} 


\section{Friday 15 Jan}

Welsh. Vendryès is sweet. Office. Kort is poison. Has installed clocking-in machines at the office to check hours spent out etc. Cinemas and theatres now not only have a day's closure a week but also no matinée showings except Saturdays, Sundays and national holidays. Gorgeous weather. Homesick. Dick. Went to Chabert's but he wasn't there.

\section{Saturday 16 Jan}

Office. "Ti-Coyo et son requin"349 (Clément Richer). Mlle Péchegut stuck to me like a leech. Told me her woes - poor thing. Came to mine despite the mess. Took the ticket money for the seminar at Mangin "Les Sciences Occultes". Sapellier and Jean were there. Jean stuck to me like a leech. I listened to the paper despite being bored and cold. Jean was not as hardy as me, left at $4.30 \mathrm{pm}$ - after Sapellier. Went to cancel wine allowance card. I'm as happy as Larry - I haven't been as happy for a long time. I feel now that I am free, free. I'd like to be in a little corner to see his face when the shopkeeper tells him the bad news!! Lesson Chabert - who gave me a bit of butter. Beautiful moon. Summons for shoes (already!!) and university medical appointment.

\section{Sunday 17 January}

Mass. C. Bought 6 oysters and after a battle of Homeric proportions, during which I had to change the knife for a penknife, I managed to open them all I'm becoming such a good housekeeper. Wanted to do a thorough tidy but unwisely started with my books so spent the whole day doing that. But I found 2 envelopes. Marvellous. I don't have any more and it is impossible to get any. Went to Madeleine Fortan's and had a delicious hot chocolate. Wanted to go to Dédés this afternoon but as he hasn't replied to my letter I didn't go. It's been a very pleasant day.

\section{Monday 18 Jan}

Office. Lesson with Pauphilet. Saw Jacqueline Eichhorn. Only got a token for slippers. Bought 1 book for degree. The others are out of print. Lesson with

${ }^{349}$ The novel was published in France in 1941. Clément Richer was from Fort-de-France in Martinique. For more on Richer, his background and the novel, see: Damiano Benvegnù (2016) 'Ti-Koyo and his Shark', humananimal brotherhood from Clément Richer to Italo Calvino and Folco Quilici Ecozon@: European journal of literature, culture and environment Vol. 7 (1) pp. 59-75. 
Gilberte Frey but only for a quarter of an hour because the library shuts at $6 \mathrm{pm}$. "Vaisseaux dans le Ciel"

\section{Tuesday 19 Jan}

Office all day. Dick. Letter from Voirin. He isn't pleased that I am still here.

\section{Wednesday 20 Jan}

Office. Bachellery. Breton. Telephoned Boissin-le-gros. Lesson with Chabert. Card from Uncle de Chateau (well, at least from Aunt Aline). Letter from Mlle Piatier. My foot really hurts.

\section{Thursday 21 Jan}

Office. Wrote Dédé a card. 2 pm visit Boissin-Legros. Upset. More injections needed. What a nuisance. I weigh around $60 \mathrm{~kg} 500.3 .30 \mathrm{pm}$. Skin allergy test 13 rue du Four. Saw Denise. 5.30 lesson with Dick. 6.45 Dr Denise Boulenger for my foot which is very swollen and sore. Rheumatism?!!! Talked with Mad. Fortan for a while. "Révolte dans la Montagne" (Meyer). Jean is a "little man" in all senses of the word.

\section{Friday 22 Jan}

Irish with Vendryès, Pneu to Aunt to tell her that I'm not going on Sunday because of my foot. Office. Lesson with Chabert. Lesson with Gilberte Frey at the PTT rue de la Boïté. Jean should find out today that he can only get a single litre of wine!!!!!! His face'll be a picture!! My foot is very painful and pain all up the leg. Worrying.

\section{Saturday 23 Jan}

Office. Mlle. Péchegut is going on a paid stint in a château on Monday. I've sorted her out some cigarettes. Went to Hôtel de Sévigné. Sapellier and Jean. Jean was a picture of despair. Listened to the seminar a bit. Jean asked: "Did you take back your wine ration?". “That's right”. He looked as if he'd been struck by lightning. My taking back my wine rations seems to have affected him more than no longer seeing me. Mlle Péchegut told me that Brémaud was swapping potatoes to get wine (despite having my card as well). That must be some loss

${ }^{350}$ Gunnarsson. Translated from the original Danish and published in France in 1942. 
for him; a greater loss than that of my love. He probably thought that I wouldn't dare do such a thing. I'm quite happy with the result - although I would have wanted to see his face in the shop. He must have had a fit and told them that it was all a lie - he must feel so stupid now. Letter from Aunt. Pneu from Dédé. $1 / 2$ hour lesson with Chabert. Got chemist stuff. Tripoli taken. Got money back on lottery ticket. Nearly bought flowers but didn't. Bought cake for 49 francs. What a disgrace!! - more than I had thought. I mustn't buy any more. Wanted to go to bed and not work or tidy as I should be doing.

\section{Sunday 24 Jan}

Went to Dédés. Aunt has lost weight. “Forte Tête” with René Dary. ${ }^{351}$

\section{Monday 25 Jan}

Office. Pauphilet ill. "My Lady Nicotine" (J Barrie). ${ }^{352}$ Lesson with Chabert.

\section{Tuesday 26 Jan}

Office. Ill. Delivered flyers. Medical examination. Lesson with Dick. Went to Delplanque's to arrange lesson. Dinner with Mlle Kerjean.

\section{Wednesday 27 Jan}

Office. Welsh. Tea with Mme Desportes. Lesson with Chabert. "L'Herbe qui tremble" (Williams).

\section{Thursday 28 Jan}

Office all day. Lesson with Gilberte. Injection. I'm putting on weight. "L'Homme au Pied Bot" Letter Mme Boussingault, Odette.

\section{Friday 29 Jan}

Welsh. Office. Lesson with Dick, Chabert.

3511942 film directed by Léon Mathot (1886-1968). See: http://www.unifrance.org/film/38024/forte-tete

${ }^{352}$ See Ian Jack's article 'Wishful Thinking' on Barrie's 1890 novel about tobacco addiction:

https://www.theguardian.com/books/2006/feb/11/featuresreviews.guardianreview13 


\section{Saturday 30 Jan}

Office. Splendid weather. Went to rue de Sévigné but no seminar. Bought flowers. Telegram Dédé. Confession. Lesson with Chabert half an hour.

\section{Sunday 31 Jan}

Mass. Went to St Denis. Grandfather's grave and "Simplet".

\section{Mon 1 Feb}

Office. Hôtel de Ville. Lesson with Delplanque, Chabert.

\section{Tues 2 Feb}

Office. Had hair cut and waved. Lesson with Dick. Made crêpes.

\section{Wed 3 Feb}

Office. Welsh. Handed out flyers. Lesson with Chabert. Letter Aunt, Mlle Pêchegut, Hélène Koch.

\section{Thursday 4 Feb}

Office all day. Lesson Gilberte Frey. Went to the Maison des Lettres. Signed up to the theatre group!!! 8.30 audition. Mimed "Le Fain" Not bad. Didn't go lesson Chabert - for possibly 20 minutes. He annoys me with these half hours all over the place.

\section{Friday 5 Feb}

Welsh. Office. Lesson with Dick. Colette came. Telephoned Aunts, Wrote to Hélène Koch.

\section{Saturday 6 Feb}

Office. Bibl. Hist. Lesson Chabert. Hairdresser. "Comédie et Proverbes" (Musset)

\section{Sunday 7 Feb}

Mass. Villeparisis, Marcel is a handsome man. 


\section{Monday 8 Feb}

Office. Lesson Pauphilet. Returned book to Mlle Appel. Lesson Delplanque, Chabert. Mme Delplanque arrested. Darned. Finished (finally) salmon pink sweater. Letter Jeanne Semaille.

\section{Tuesday 9 Feb}

Office. Was paid by the Soc. des Musicians. Went to the Red Cross. "No news. Worried. Uncle Corbeil died. Zeau. André, all friends send fond wishes. Another haircut; permanent wave; obvious improvement. Health good. Much love. Thinking of you constantly. Madeleine". Lesson Dick. Went to bed early. Wrote to Colette. Aunt. "Vieux coeur en voyage" (Hans Fallada). ${ }^{353}$ Office all day.

\section{Wednesday $10 \mathrm{Feb}$}

Office. Welsh. Bachellery. Hôtel de Ville for posters. Chabert.

\section{Thursday 11 Feb}

Office all day. André telephoned. He is going to Germany on Monday. ${ }^{354}$ Injection. Lesson Gilberte Frey. Wrote to Hélène Koch. Prepped Welsh.

\section{Friday 12 Feb}

Welsh with Vendryès. Bachellery didn't show. His wife is worse? Office. Giselle de Mesnil not there. She is leaving. Lessons Chabert, Dick. Telephoned Aunt.

\section{Saturday 13 Feb}

Office. Injection. Hôtel de Sévigné (Jean was there. "Why thank you" in response to my filthy look. Lesson Chabert. Signed up to a French language group. "Theatre" (Sacha Guitry)

${ }^{353}$ Written by German novelist Hans Fallada (1893-1947) See the site Et puis après? Actualités littérature autour de Hans Fallada for a contemporaneous 1942 review of Fallada's novel and background about the novelist:

http://etpuisapres.hautetfort.com/archive/2017/04/16/vieux-coeur-en-voyagerecension-le-journal-21-avril-1942-5933439.html

${ }^{354}$ It is unclear whether this is voluntary or obligatory work service in Germany. 


\section{Sunday 14 Feb}

Mass. St Denis with Yolande. Came back to Paris with Colette to get ham. "Les Petits Riens"355 (stupid). Dinner with Dédé. He is leaving tomorrow. Race for the train "I'll kiss you another time". How grown up he is!

\section{Monday 15 Feb}

Office. Hôtel de Ville to see Mme Boussingault - not there - heard Jean's voice talking politics (his sickly voice irritates me) so I left. Lesson Pauphilet. Lesson Delplanque, Chabert. Injection. Ruth came to borrow my typewriter - I refused. She only calls by when she needs me and so I politely showed her the door. Wrote C. Péchegut. Rain.

\section{Tues 16 Feb}

Office all day. Sent cigarettes C. Péchegut. Hôtel de Ville. C. Péchegut there. Sold cigarettes to Mme Boussingault. Jean's eyes popped out of his head when he saw the cigarettes. He wanted to take me to one side to talk but my way out was covered by Soulié. Lesson Dick. Slept badly.

\section{Wed 17 Feb}

Office. Welsh. Bachellery. They are saying students have to leave for Germany on Sunday but everything is on hold for the moment. Wrote to Aunt Violette. Injection. Lesson Chabert.

\section{Thursday 18 February}

Granny's birthday. Was at the office all day. Mme Boisin-Legros. Huge joy. I will have to get married between 25 and 30 but not later than 30 that's for sure so as not to go mad. Damn it. I know that I am attractive. Bought a mirror and a comb for Gaël. Locket for Kitty. Went to Dilys's place, made dinner for Gaël. Dil. came over later to speak to me about Françoise. Miss Beach is back from the camp. ${ }^{356}$ Kort has a limp or, at least he does when he remembers (is this to get my sympathy or to get out of going to Germany?) (either way, he's sniffing around me) Lesson Gilberte Frey. Cold. Sent a few words and a drawing for Denise.

${ }^{355} 1942$ film directed by René Leboursier starring Raimu and Fernandel. http://en.unifrance.org/movie/7608/les-petits-riens

356 Sylvia Beach was released from internment in Vittel. 


\section{Friday 19 Feb}

Welsh Vendryès. Office. Kort charming. Denise telephoned. Student of dental surgery spoke through the whole of lunch. Lesson Dick, Chabert. Chabert suggested an outing tomorrow. I accepted. Why not? Injection. Big smile. Mme Delplanque came back. "Croix du Sud".

\section{Saturday 20 Feb}

Office. Seminar rue de Sévigné. Went to Chabert's. He bought me an ice cream at Pons (yum yum). Colette came to eat. Note from Cyla.

\section{Sunday 21 Feb}

Mass. Villeparisis. Beautiful day. Walk round the pond. Last injection.

\section{Monday 22 Feb 1943}

Office. Queue for food ration card. Mlle Delplanque did not come. Lesson Chabert. The Swiss woman (Mme Laberrie) and young German officer were there. Very misty. Housework.

\section{Tuesday 23 Feb}

Office all day. Wrote to Cyla. Did washing. Lesson with Dick. Very misty.

\section{Wednesday 24 Feb}

Office. Welsh Bachellery. Spoke to M. Kermarec - lent me "20 ans de Jeunesse" (Maurice O'Sullivan). ${ }^{357}$ Tea with Marguerite Desportes. Lesson with Chabert. Pneu from rue Henner about getting paid tomorrow - have I gone back to 460 frs? That wouldn't be on - I'll leave.

\section{Thursday 25 Feb}

Office all day. Pay was still the same. Lesson Gilberte Frey. Went for dinner at Giselle de Mesnil's. Cold. Saw daffodils at the florists.

Maurice O'Sullivan. Irish writer. The novel was translated into French by Raymond Queneau in 1934. See: Etudes irlandaises for Claude Fierobe's 1998 compte rendu:

https://www.persee.fr/doc/irlan_0183-973x_1998_num_23_2_1471_ t1_0182_0000_5 


\section{Friday 26 Feb}

Welsh Vendryès. Office. So it seems that I'll have to do 32 hours a week? What next? 3 hours less than those on 2,200 - and me on 1,400? And what about my studies? I want to leave - but go where to earn money? I'd happily do 32 hours a week at home - but not in the office. Plumber came. He was wearing a bowler hat - like the ones in England. Is that a requirement of the job? Lessons Dick, Chabert. Saw a fellow in the street, pallid, shaky on his feet, hunched over, tongue swollen up and hanging out, frothy yellow saliva. The bobby was keeping his distance. Latin translation. Wrote to Aunt. Jacqueline Piatier came back. Tired.

\section{Saturday 27 Feb}

Office. Went to the Bibl. Hist. Costumes hadn't arrived. Soulié not there. Desperate telephone calls. The office boy grabbed me by the waist in the corridor!!! Since I've had my hair cut I'm being called out at in the street, something that hasn't happened to me since I was 19!! Very amused by Jean who turned up dressed up to the nines and thinking himself very chic in his black overcoat. Beside himself that I paid no attention to him. "Beau temps - pour une promenade à la campagne". He said this very slowly and intently whilst staring at me. Found out that he is a detested little sneak. Lesson Chabert. Went to Colette's for a Latin translation. She has a big bedroom with 2 windows. Same sort of home-made things (bookshelves out of planks, table etc). Fine weather but cold.

(Saw that the fire station on Bd Pont-Royal all shuttered up. Françoise B. told me that young people who did not register their names at the first census are being held there. Tuesday 9 March). ${ }^{358}$

\section{Sunday 28 Feb}

Mass. Did a bit of housework. Drank 3 glasses of wine - number 1 was bad, the other two were good - will I become a lover of drink? Fine weather. I have been hearing the first cooings of pigeons for about a week now. In my box, baby forget-me-nots are growing - there is a crocus too. Did I say that a daffodil was going to flower? I must do some mending. Tired but feel very positive. I have two lumps under my eyelids. It must be like last year. It is so splendidly sunny, not a cloud. The trees of the Val-de-Grâce are not in bud but they are a shade of brown which anticipates the rose colour of the leaves to come. The branches are white in the sun. My first fly of the year climbed up the window pane.

Rations for the month of March: per week - 90 grams of meat, per day - 275 grams of bread, per month: -310 grams of fat. 160 grams of cheese. 1 pound of sugar - 150 grams of coffee

358 Note added on 9 March. 
250 grams of pasta - 150 grams of soap (including soap for the bathroom).

Darned. Mad. Fortan came to chat. 2 ankle socks: 4 hours of repairs. I shouldn't let there be such big holes - but the socks are of such poor quality; and even though I have had them for 8 months I can't replace them because I have neither points nor money (for black market).

(the baby forget-me-nots were only weeds 25 July) ${ }^{359}$

\section{Monday 1 March}

Gymnastic exercises. Office. So, I'm having to do 32 hours!!! Shall I leave? Or go back to 2,200 - if they will have me. Saw Mlle Péchegut. So Jean is complaining that I treated him badly - like a subordinate, He is doing all he can to sully my good name. He's playing the little blackmailer! What a wretched fellow - I can understand why he is not liked. Paid the Gas. Went to the Soc. des gens de lettres to get money. Housework. Mlle Delplanque came for her lesson. She is very afraid of me. Lesson Chabert. Madeleine Fortan invited me for dinner at her friend Marcelle's. Vermouth, noodles, fried potatoes, sugar and biscuit de soldat. ${ }^{360}$ Very tired so went to bed.

\section{Tuesday 2 March}

Office all day. Didn't do any exercise because my stomach hurts. I've had pains in the stomach now for 15 days. I can cope with it. It's more a dull ache than anything. It's like I've been hit hard there but I remember nothing about it. So, we are expected to work 32 hours a week now - but neither party is insisting and we manage to get away with not doing it. I really need that degree ${ }^{361}$ if I am going to find work or if I want to earn more. Bought daffodils - they are beautiful, really divine. It'd have been nicer if they had their own leaves instead of the ferns even though they are pretty. Watered the plants. The dryness is killing them and I don't look after them enough. Worked here. Lesson with Dick. Bought $1 \mathrm{~kg}$ of rice for 250 francs. I'm mad but I'll be glad of it later. Mad. Fortan came to mine. She's going to get ill. Finished "Vingt ans de Jeunesse" (Maurice O'Sullivan). Very good. I am working in the light of the little lamp. It is a pool of light. The rest of the room is in shadow. The daffs are a transparent yellow in the light with a green tint like flowers in a dream that drift

359 A note added on 25 July.

${ }^{360}$ Also called the 'pain de guerre'. More on the biscuit and its history can be read (in French) here:

http://www.compagnons-boulangers-patissiers.com/crebesc/pain-de-geurre/

361 The degree in English Madeleine registers for in 1940 which will qualify her to teach in schools in France. Her doctoral thesis remains her priority but there was no telling, in 1940, just how long the war would last. 
downwards through a green sea. Madeleine F and Jacqueline Piater are chatting in the corridor. I won't go out. I have to get on with studying.

(A bomb was thrown at the soldiers' restaurant Bd' Mich' at around 21 hours Chabert told me $)^{362}$

\section{Wednesday 3 March}

Office. Welsh. Bachellery. Chicory. Chabert for an hour. I'll only have two hours a week from now on - a lesson down and I need the money. Never mind. Wrote to Aunt.

\section{Thursday 4 March}

Office all day. Lesson with Gilberte Frey. Letter from Mme Faure. Wrote to Mme Faure.

\section{Friday 5 March}

Welsh with Vendryès. Office. Giselle telephoned. Went to Dick's but not there.

\section{Saturday 6 March}

Office. Rue de Sévigné. Sapellier and me. "Du côté de chez Swann" by Proust. ${ }^{363}$ I am thrilled by it. It is marvellous, powerful, this evocation of the past. Such artistry. Identity checks at the concert at Ecole Normale Sup de Musique. Jean came. "What is dead is dead but that is no reason not to stay good friends", he says. Fair enough, but I don't want it to be a starting point for an attempt to win me over again. Got an insight into the thoughts of a chic well-dressed young woman, clearly from a very good background, when her papers are checked by mistake 3 times. "Ah! They really bloody annoy me!!" (!!!) Went to the concert. Very good. Loved the harp. The cellist played very well, particularly the "noisy bit". Astonishing foreshortening of her when viewed from above, like a ball, in a black velvet dress, rounded white arms bent around this large instrument. The violinist had a perfect technique but played with no feeling. Jacqueline Piatier is leaving for a while, left me some flowers to look after. Confession.

\section{Sunday 7 March}

St Thomas Aquinas. Mass. C. Beautiful day just as I like them, the air cold; wind - a retreating horizon - for the first time this year, the houses stand out

362 Written in brackets in the margin alongside the entry for 2 March.

${ }^{363}$ Marcel Proust, French novelist (1871-1922). Du côte de chez Swann was published in 1913. 
and behind them the shadow of the mountains. I should go out to enjoy the beautiful weather but my foot is very painful again after yesterday (all day in little red shoes). There are also too many people. Read Proust. Am bowled over by it. What a great style, what description, what atmosphere!! I'm going to unpick my coat so I can have it turned up. A daffodil (the only one) on my balcony has broken through its envelope of dead leaf, yellowed its green pod before its trumpet burst through. Baby forget-me-nots are coming through everywhere. I am going to instil some order amidst their sproutings. But, what flowers shall I put in? I haven't got room for everything. I'll have to make a choice. (Boutillier du Retail - director of the Centre de Documentation at the $\mathrm{BN}$ is dead).

\section{Monday 8 March}

Intended to do some thorough housework but didn't really feel up to it and because I hadn't yet finished unpicking the stitching of my coat I set about doing that. I haven't yet finished. It takes a long time to unpick it stitch by stitch particularly because it has been done by machine. Cécile P. received some bad news from home. She's got a hard life and not a lot of friends because of her off-putting manner. She has a heart of gold - but her table manners are horrendous. Françoise B. came over. Alas, she is making visits "Jacqueline style" 4 and a half hours!!!! Very nice, but she stays too long. Then the lesson with Marguerite Deplanque who didn't turn up - got a pneu from her at 6 o'clock - a bit late! Oh well! Françoise must be bored - talked about art, literature, music, war. I must go to see her. She seems to want to have me as a friend. She's always prompting meets! Lesson with Chabert. Very bawdy. Very attracted by sexual matters - the only thing he remembers about London is the prostitution. Wants my views on prostitutes etc. Good God, men here are really obsessed with sex!! Strange - on a different matter - to see his reaction to the "Pugna Thermopylae" at the Concert Colonne. His opinions very different to those of Françoise. He sees himself as very radical for liking it. I would have had to have heard it to be able to appreciate it - even though I am not an authority on music - to see what it is about. Mad. Fortan lost - or has had stolen - her beautiful suede belt in the office. She is so upset. The nights are very fresh. Woke up at 2 am shivering. Had left the window ajar, but I had more covers over me than I usually have. Round $11 \mathrm{pm}$ and $2 \mathrm{pm}$ anti-aircraft fire was pounding away. They must be going into Italy. Beautiful day, beautiful sun but cold.

\section{Tuesday 9 March}

Mardi gras. I'll have to buy myself a bit of butter to make myself some crepes (without milk, eggs, vanilla, sugar). Replanted the snapdragon - wanted to throw it out but it would have broken my heart to condemn it to die so I put it in a pot. I don't know whether it will survive. My little geranium is fighting hard for its life so many times I've thought it dead when I've left it out in the cold or taken it from 
the warm bedroom or forgotten to water it. What a lesson in vitality and fight it gives. Had a glass of wine and 50 grams of bread for my lunch - bah! When I go back to the market (because I am going to the market for the first time since August) I'll get myself a slice of bread and butter. I will have to throw out my daffodils. They are not completely withered but the scent of dying daffodil bothers me, it jumps out at me when I walk into the room or when a brisk movement stirs the air. The sparrows are chirping at the window for crumbs - but I don't have any. The mist is thick this morning and one can't see further than the trees behind the square building of the Val-de-Grâce. At the market - long queues in front of the 3 stallholders selling cauliflowers. Carrots could be had with a ticket (which I no longer have) and artichokes (which give me stomach ache). Bought 12 oysters, dandelions, thyme, bay leaves etc. No butter at Dubois. Will they have any this evening? No nice flowers. I'll make myself a stew with my last potatoes and half a carrot. If it's simmered for a while it might work? Lesson with Dick.

\section{Wednesday 10 March}

Sent money to the Ecole Universelle. What will come of that? Welsh with Bachellery. He is such a crashing bore. It's awful. Finished unpicking my coat. I only have to take it up now. Official announcement of death of Boutellier du Retail. Died Sunday. Sent carte de visite with condolences.

\section{Thursday 11 March}

Tacked coat. 1 pm lesson with Chabert with Mme Laberrie. Chabert very flustered by the presence of Mme L - did an atrocious dictation. Went to the hairdressers to have hair curled. Not very pleased. Went to Mme Faure's who said that Yolande had had congestion in her lungs but that she had not taken time off work!!!!!!!! Phew! Well that's quite something (she could make that up about a simple cold. Never believe anything she says). When I got home I typed up article [...] then prepped Welsh until 5 in the morning. Not hungry nor tired. My anxiety attacks are back. Stomach very painful like as if I had been punched - pain in the side. It must be an attack of appendicitis.

\section{Friday 12 March}

Woken up at 8 am by Jacqueline Piatier who gave me 2 eggs and told me that she has got engaged!! The doctors who looked after her must be good. Welsh with Vendryès. Went to book a place for the theatre with Mme Faure. There are only places for Wednesday left. Went by the bank to see Aunt. Her cousin Jean from Verrières has died, fell under a métro train at Massy-Verrières. "Maybe he had an attack of dizziness?' - "He takes his secret with him"!! - Shades ${ }^{364}$ of

364 'Shades' written in English in the manuscript. 
Henri Bordeaux!! Went to the Soc. des Musiciens. Lesson with Dick, Chabert. Anxiety.

\section{Saturday 13 March}

Slept in late. Went to rue de Sévigné - forced to stay until the end, because Villabella (?) Fontoblia was there. Got ready for Colette coming over, cake etc but she has the flu and so she's not coming - all that expense for nothing - and having to eat into my stocks of beans - oh well, never mind.

\section{Sunday 14 March}

Didn't go to mass because talked too long to Mad.F. Villeparisis. Everyone charming. A few anemones in the woods; a blue vetch, a few catkins. There are a few primroses in the gardens; lilac in bud.

\section{Monday 15 March}

Office. Went Hôtel de Ville to see Fontoblia for posters. Lesson with Delplanque, Chabert. Dilys came - she is going to ask me something!!! Started to study seriously. Anxiety attacks. Eaten too many beans - Gosh I'm bloated. My daffodils are opening nicely. They are still a little greenish. No more shop window displays. The antique dealers have their windows painted white with just a little opening to show a small item of furniture. It is ridiculous. Wrote to Colette and the theatre circle.

\section{Tuesday 16 March}

Office all day. Lesson with Dick. His mistress was on her way out. She's pretty, although a bit tubby.

\section{Wednesday 17 March}

Office. Handed out posters. Shattered because it was hot. Saw an adorable little pot in Dresden porcelain - a windmill, 2 houses, blue on white. Bought it. I (very pleased but tired). Hôtel de Ville. Welsh with Bachellery. "La Baie de Destin" (Byrne). ${ }^{365}$ Very good. Wolfed 3 biscuits and then rushed to the Atelier for "L'Honorable M. Pepys", with Mme Faure and one of her friends. The benches are awful in the Gods. The play was fun, had some go about it. Enjoyed myself. Dead tired.

365 Donn Byrne (1889-1928 ). Translated by Maurice Rancès and published in 1931 in France. See bibliographic entry at the Bibliothèque nationale: http://data.bnf.fr/12105697/maurice_rances/\#rdt680-12105697 


\section{Thursday 18 March}

Office all day. Lesson with Gilberte Frey. Went to Giselle de Mesnil's for potatoes. I.

\section{Friday 19 March}

Welsh with Vendryès, Office. Lesson with Dick. Wangled 1,250 g worth of bread tickets from the Centre. Very hungry. What lovely weather.

\section{Saturday 20 March}

Office. Kort furious that we were reading the newspaper. Bibl. Hist. the singer didn't turn up and I had to announce that to the audience. Not good. Confession. Dinner with Mad. Fortan and her friend Marcelle. Pneu from Aunt. Card from Jean de Dex.

\section{Sunday 21 March}

Communion. Mass. Changed the bedroom around. Very pleased because the room seems bigger. Made a bedroom area and a lounge. Darned. I.

\section{Monday 22 Mar}

Office. Posters. Hôtel de Ville. Didn’t see Fontoblia. Went to Françoise Boësse's, not there. Saw an almond tree, in full flower. The chestnut trees are bursting into blossom. One can see them opening up hour by hour. I'm not exaggerating. I will never get used to these Springs which explode like a bomb. Yesterday I listened to a speech by $\mathrm{Ch}-\mathrm{L}$. War over ' 44 or ' $45 .{ }^{366} \mathrm{Oh}$, crikey me!! Will I live to see the day? The sty in my eye has burst. 15 days now without any butter. Wrote to Aunt. Yesterday night there was a strong smell of burning wood. Me and two little girls told the concierge. Turns out that the Zazous downstairs were burning a floorboard!!

366 This may have been a speech by Charles de Gaulle made on 18 March 1943 and broadcast on Radio Londres. Madeleine was not always accurate with dates so the fact that she noted this down on 22 March does not entirely exclude the possibility that she is referring to this speech. For more information about De Gaulle's wartime broadcasts from London and the reference to the 1943 speech (p.181), see: Marie Geffray (2011) Charles de Gaulle et André Malraux, le discours et l'action (Paris: Éditions François Xavier de Guibert). 


\section{Tuesday 23 March}

Office all day. Kort was poisonous. Bought return métro tickets. Lesson with Delplanque - paid me thank goodness (I only had 10 francs left). Many compliments about the new bedroom layout. Dick wasn't there but I will count that lesson. I have had enough. "Roman du Lièvre" (Francis Jammes).

\section{Wednesday 24 March}

Mummy's birthday. Office. It rained a little. Welsh with Bachellery. He is such a yawn. Tea at Maggy Desportes's. Ketty cried a lot. Izou is adorable. I must get some expensive wine - I got some for 20 francs 10 centimes!!! I really have to work - or what will happen with the exam? Got ration card for food but not for coal because the queue was too long. I will go early Friday morning. My eyelid has gone down a lot. "Leçon d’amour dans un parc" (René Boylevsé) "Le Vieillesse d'Hélène" (J. Lemaitre) It is bad to read instead of working - I really need to get down to it. Raining heavily.

\section{Thursday 25 March}

Woke up late. Office all day. Kort was poisonous. Beautiful sunny day. This lunchtime spoke with the young woman about theses - I didn't recognise her. Absolutely tired out - so didn't work. I wanted to but my head is spinning and the words are spilling around like water in a spring. I went to bed at $10 \mathrm{pm}$ to try to come round a bit. Dark and warm night, a strong scent coming from my stocks.

\section{Friday 26 March}

Coal ration card. Welsh with Vendryès. Bought 'South Riding' (Winifred Holtby. ${ }^{367} \mathrm{I}$ am so very happy because it is a book I've wanted for such a long time. Rain. Office. Lesson with Dick. It warms my heart to see Leeds-YorkAlderman in print. Je belong au Yorkshire. ${ }^{368}$ Slightly depressed because of homesickness? ${ }^{369}$ I've had enough of eating noodles, potatoes, noodles, potatoes since October. 10.15. It's pounding away.

367 Winifred Holtby (1898-1935). Associated with British inter-war women 'middlebrow' writers. Madeleine evokes the North Yorkshire landscape of home through Holtby's novels.

368 'Je belong au Yorkshire' written in French and English in the manuscript.

369 'homesickness' written in English. 


\section{Saturday 27 March}

Office. "Litt. épique et poésie hindoue". Brémaud was there to work the projector. Mme de Mesnil came. Colette came in the evening for the translation. Not yet able to throw her out. My beans were very good. Lesson Chabert.

\section{Sunday 28 March}

Mass. C. Washed coloureds. Housework. Mended.

\section{Monday 29 March}

Office all day. Cold. Paid. Lesson with Delplanque who brought me "Le Livre de San Michele" (Axel Munthe) ${ }^{370}$ It is brilliant, brilliant, - but I read it until 2 am. [...]

\section{Tue 30 March}

Office all day. Did ironing. Bought cauliflowers. Bought books so as not to waste my ration tickets before they go out of date. Lesson with Dick.

\section{Wed 31 March}

Office all day. Rain. Wrote to the Librairie Carus because still not got the paper. Little bookshop below. Was so upset yesterday. They took all my points from one card (I had 198 francs worth!!!! - and put them with the 130 frs from the other card!). That's 300 frs that I was not planning on spending. It is going to be tight again this month. I need to be careful. The trees in the Luxembourg Garden are all green. Bachellery had a son 3 days ago. Went to Giselle's for dinner and pancakes. The pancakes stuck but the flour was made out of broad beans! Nasty letter from Aunt "We don't make a habit of going to houses where fun is all that matters"!!!! "I was going to send you a pneu but didn't have the time. You couldn't apologise but you weren't going to, maybe" (perhaps an add-on doesn't even have the courage of her convictions). Marcel had come. I am sure that she was only too pleased not to write to me. I must be the main topic of conversation between Yo and Aunt - as if they have nothing better to talk about!!

${ }^{370}$ Axel Munthe (1857-1949). Memoirs of Capri and the cultural circle in which Munthe worked and socialised. 


\section{Thursday 1 April}

Wrote to Aunt. Started writing up diary. ${ }^{371}$ Office all day. Giselle came to the office. Lesson G. Frey. During her lesson everything went black and started to swim. Ate 2 mushroom crepes without tickets and felt a lot better. Everyone thinks that I am prettier and prettier - delicate features etc etc. Nothing but flowers left. The little shopkeeper woman opposite is pushing it - one little lettuce with three leaves for 5 francs!! Ate some radishes today for the first time this year. In the office, everyone pinning little paper fishes to their neighbours' backs. A circular came round - students work 24 hours a week instead of 32 but because it's all fiddled, it only means one and a half hours less. Kort is losing his marbles - after making Bertin-Conrad take the iron minerals stuff out of the iron file he made Deirdre and me put it all back exactly how it was before!! Haven't they got anything more useful for us to do? So we started doing our own work for our studies. He was flitting around us doing nothing useful himself and didn't dare say anything.

\section{Friday 2 April}

Welsh. Vendryès. Vendryès very worried and cross. A record has been made of the names of foreigners at the Faculty. Office. Bertin-Conrad has been demoted - now he is filing etc. Went to Hôtel de Ville (saw Soulié, Fontoblia. Bought one artemisia, one begonia with the money I wangled (they hadn't marked up the commission on the tobacco). 10 minute lesson with Dick, having waited for him for 50 minutes. There won't be any seminars on Saturdays for a long time. That's rotten luck, 200 francs less!!! But one plus - Saturday afternoon free and more opportunity to see J, thank God. Mlle Péchegut is ill. I must take her some flowers - perhaps. Jacqueline Piatier must be getting ready to move out - saw the furniture being shifted. I think that her mother is with her. All the chestnut trees except one in the square in front of ND are in full leaf. What a beautiful fresh wind blowing in the sun.

\section{Saturday 3 April}

Office. When I got back Dilys came round. On verge of nervous break-down. ${ }^{372}$ Went to Dilys's straightaway and she gave me Georges' meat ration tickets and an egg. She wants me to take Gaël to Poitiers. It is a long way, but I'll go. Did Latin translation for Colette, but when I went over, I didn't breathe a word

371 'diary' written in English. This is the first hint that Madeleine may be transcribing notes made during the day into the diary 'in neat'.

372 This sentence - 'on verge of nervous breakdown' - in English in the original manuscript. 
about it other than when I gave her the book back. Lesson with Chabert - half an hour. Went to Colette's. Her mother came. Her mother is a bit deaf and a bit fussy, ${ }^{373}$ and very proud of her daughter. Colette found her mother's presence awkward in front of friends. She curled herself up ${ }^{374}$ like a tiny little girl. Another friend came. She was a rough sort. I think I'm rid of her - or perhaps C. no longer needs me to be spied on. That suits me.

\section{Sunday 4 April}

Mass. C. Splendid weather. Beautifully sunny. Housework. Wrote up diary. 2.15 air raid warning. Heavy firing. The birds are terrified. Mad. F came over. We stayed at the window for a good hour until the end of the alert. I've got a bit of a headache. What superb sun. I can make out the houses behind the forest at Vincennes which is still completely grey. Three chestnut trees are in leaf at the Val-de G. The other trees are a browny yellow; a colour which comes ahead of the green. Lots of bees are heading for my wallflower!! Going to eat a slice of bread and butter (although it's extravagant) and I'll get back to copying out the diary. I'll be a lot neater doing this. I'll do some mending this evening by lamplight. 10.45-11.30. Alert. Renault at Boulogne-Billancourt was bombed this afternoon.

\section{Monday 5 April}

Office. Cold at the office but boiling later on. Put posters up. It isn't the going back and forth that is exhausting but the going from floor to floor. Had the surprise of my life at Luxembourg. The buds on the chestnut trees are about to open out!! And only 8 days ago there was barely a dusting of green!! 4.30-4.50 air raid warning. Went to Dilys's. Jacqueline Eichhorn was there. The little girl is so well behaved and mature for her age. Wrote to Dick to cancel the lesson for tomorrow. Marguerite Delplanque arrived $3 / 4$ hour late so gave her a lesson for $1 / 4$ of an hour. Lesson with Chabert. Dilys came over about the arrangements for tomorrow. She found a pile of excuses for sending Georges and Gaël away. The truth is that she does not love them She's the sort of woman who would like to have lovers - not a home life - and to think that there are women who would love to have children, a home to be proud of (me) and who don't get married. She is tired but she only has to give up a few lessons. Smoking tobacco is the only thing that keeps her going. Did some mending. To think I'll have to be up tomorrow at 5 o'clock (3 oclock with the sun - or no sun). What heroics!!!

\footnotetext{
373 'fussy' in English in the manuscript.

${ }^{374}$ Written 'se curl up' in the manuscript.
} 


\section{Tuesday 6 April}

5 am alarm. 6.15 over to Dilys's. 7 am to the train. 7.45 am train leaves. 11.15 arrived in Poitiers. 5.10 pm leave Poitiers. 9.15 pm arrived Paris. $10 \mathrm{pm}$ at Dilys's. 11.15 back at mine. $12 \mathrm{pm}$ in bed. Wonderful day. It was raining when we left in the morning. Had Gaël on my knees the whole time but she was so lovely, not like the little horrors, boy and girl, who wouldn't sit still in the compartment and were fighting, yelling, crying and rolling around on the floor etc. It was the opposite with Gaël who was encouraged to be more sensible because everybody was enthusing about how sensible she was. Dilys was heavy hearted to see her little girl leave. Because I couldn't open the case of toys en route I produced my little toy dog - but disaster struck. Because it made her cry she woke up the real dog sat on the lap of the woman next to me. Melodrama untangling the real dog, Gaël and the toy dog. Gaël won over the Gentleman-with-the-dog. Arrived in Poitiers, no Georges but he came later after lunch. Gaël slept and when she woke she was as fresh as a daisy and thrilled by the little kittens which she called "little ducks", she so wants to see little ducks. She was just lovely when she saw her father, she bunched herself up, her arms crossed tightly and wriggled around just like a puppy - all the while stamping her feet. She is just so lovely, I don't understand why her mother wants to get her off her hands. The trees are all in bloom - huge blue bouquets everywhere. Very little pink - which is a shame, pink is so pretty. Near Orleans, the lilac is in flower. At Poitiers there was wisteria and in the cracks in the walls there were yellow wallflowers. I was thrilled to bits when we went over the Loire - the beautiful Loire - wide, shallow - sandbanks and so, so blue. I had not anticipated that I would be so moved. On the way back, saw my "first" chateau de la Loire set against the greenery, another thrill. It was such a wonder I wanted to yell out. It was only a passing glimpse but it was very clear - two octagonal towers (?) which must be so richly worked and which must have a staircase inside - (I don't know that but I would like it to be the case) At Poitiers, old churches. I didn't have a clue about the layout of the town and Georges did not help but I think that I saw the main bits. Went to the cathedral St Pierre (XI-XIII centuries) which is sunk in the earth right up to the top of the gate. There are a dozen steps to climb down to get into the cathedral which is very light (the windows have had to be taken out), spacious and cold. Then tried to go into a strange little chapel which was shut, then walked around St Jean's basilica (IV century), circular, (not Roman style, couldn't find it in the Larousse). The roof comes down to the road; a moat has been dug around it. It's funny how these things are sunk into the earth. Saw Notre-Dame la Grande (Roman style). Very pretty inside with all its frescos which are so bright and cheerful, so fresh. They've gone from the bases of the pillars, rubbed off by centuries of worshippers but so dazzling higher up and in the dome. St Michel - not that interesting other than it is like two churches stuck side by side. Got a little bit lost, not knowing the name of the hotel, but found my way after a few panicked moments. Went 
to the Salle des Pas Perdus (Palais de Justice) an old chateau belonging to the dukes of something or other I can't remember. I finally realised that I was in the great hall of a chateau - at the top end with a dais and three chimneys. Ghosts of Lancelot and Perceval. Because I was on my own I could go into the chimneys to see the sky, going from one end to the other and everything. Pretty.

Bought a pair of gloves from a young girl in regional dress who makes them. A bit expensive but never mind. Sent a card to Denise Pedon.

On the way back saw lots of different colours of earth - very white then browner. There is a beautiful cathedral at Orleans. Saw my pretty Loire again.

Brought back 2 doz eggs, 2 camembert to share between Dilys and me - she said: "Stay to dinner", I had to be persuaded but I stay. 1 egg on the plate, purée, a bit of camembert. "That makes 8 eggs for you" she says (yes, if her mother is counted in). But she makes off with the two camembert (and mine?). When I get home I see that I have only 7 (seven) eggs. She served me "my" egg at dinner "given" (?) by her. What a strange way to work it. Luckily I had bought two cheeses without tickets without fat. ${ }^{375}$ which are not bad. If I had known I would have bought more. Finished off Gaël's coffee in the flask.

\section{Wednesday 7 April}

Office. Windy enough to blow you away. Rain. Hail. Finished taking the posters. Welsh with Bachellery. His son is called William. Went to Hôtel de Ville but Fontoblia wasn't there. Went to Dick's but not there. 30 francs lost that Dilys despite her promises won't ever pay me. She didn't come this evening (she was supposedly coming to bring me some potatoes) - Oh I couldn't care less, I know what she is like - but the camembert that was whipped from under my nose upset me. Had a bit of a fright - thought the flask was broken because it makes a funny noise like sand when shaken. Mad. F says its nothing. I'm dead tired and aching all over. I had Gaël for over 7 hours!! I'm wondering whether I will have enough money to pay my rent. Tired out. Aching. Headache, cold, eyes stinging, hungry (despite hefty dinner ${ }^{376}$ ), going to bed. Tomorrow I'll be alright again.

\section{Thursday 8 April}

Office all day. Very very cold. Lesson with Gilberte Frey. Received a summons to go to the Maison des Lettres for community service in the event of Paris being bombed, one afternoon a month. Can't refuse. Worked on the stats for

${ }^{375}$ Ambiguous. 'sans tickets, sans matières grasses' may mean without the tickets used for oil/fat products or may mean cheese which does not contain fat.

376 'hefty dinner' written in English in the manuscript. 
Chabert. Wrote to Aunt. Jacqueline Piatier came to ask for details in order to find me a job as a tutor - I can't see that happening.

\section{Friday 9 April}

Welsh. Vendryès. Office. Lesson with Dick. Worked for Chabert. Saw Mlle Péchegut who is getting over bronchitis. She is in love with Brémaud. All she does is talk about him.

\section{Saturday 10 April}

Office. Brought calculations to do at the office, Finished the work for Chabert. Went to the Maison des Lettres for public service. Brilliant seminar by M Leroy (?) Was telephoned about those who were bombed out at Billancourt but was stood down by the Maison des Lettres when I went to sign up. Soulié telephoned. Didn't understand a word of what he was saying. Had to phone Mme Boussingault. Had dinner at Dilys's. Jacqueline Eichhorn was there. Dilys planning on freshening up all her old dresses. She's very impressed by what she packs into her lessons. 10.45-12 pm air raid warning. Bought a pound of sugar on the black market despite not having any money.

\section{Sunday 11 April}

Aunt's birthday. Mass C. Dreamt that mummy came. Am a bit worried because I've not had any news at all. I'll write to Nils. Made potato quenelles, one egg, half an onion. But they really did need some flour!! Amazed. Stuffed them down and fell asleep. 2.15-4 am, air raid warning. Went to rue du Conservatoire to hand out leaflets for the next concert. Soulié was in a bad mood. Brémaud was there. Mad. Fortan bored me for an hour. Saw Jean-Louis Barrault who was striding towards the concert. He had a disdainful, fed up expression. I wouldn't like to know him personally. Did the work for Chabert but because it needs very careful checking - it is maths and I am useless at it - I can only ask him for half of the time spent on it which works out at $7 \mathrm{fr} 50$ an hour. It isn't enough. I'll refuse his next batch of sums.

\section{Monday 12 April}

Tiring and disappointing day. Office - got yelled at by Kort who told me that he'd show me the door if I was late again - and I'm rarely late. Went to Hôtel de Ville for voucher. Went to rue V. Massé to get paid but didn't. Not enough time to go to the Red Cross because of the lesson. Waited for half an hour to telephone Soulié. Waited for Delplanque but didn't come - received pneu at 6 o'clock. Foot hurting. Want to cry. Upset. Lesson with Chabert. Gave me 2 eggs in part payment for the statistics. Mme Laberrie came to see Chabert. 
"Noeud de Vipères" (Fr. Mauriac). ${ }^{377}$ Had already read it but enjoyed re-reading it. Tired out. Bed: 1 am. Harry Baur was buried, cinema actor who died straight after his release from a concentration camp. ${ }^{378}$ The supply of electricity has been cut to $6 \mathrm{kw}$ a month!!! It is simply impossible, I’ve already used 3 in a week!

\section{Tuesday 13 April}

Office all day. Warm outside cold in the office. Lesson with Dick. Not with Delplanque who came but not for a lesson but because invited by Dilys to see "Les Visiteurs du Soir" 379 (v. good). Motive: so that I look after her mother when she is busy. Letter from Aunt which was as catty ${ }^{380}$ as anything. Says "well I never", that I am inviting her over for the first time - what she means is that this is the first time she has deigned to accept. Tells me that I have plenty of time for my studies and that this is more a case of me changing my tune. In other words "My dear girl, I don't believe a word you say". And what's more "It's Palm Sunday and Godly people go visit cemeteries". I didn't know. Anyway, whilst I am not particularly pious I don't speak ill of my neighbours as much as she does. Ah, well who cares!! Let her moan on!! She and Yo must be dying of jealousy. I couldn't care less. I wouldn't want to be in their place for all the tea in China. But loving Aunt as I do, this does hurt - I'm learning.

\section{Wednesday 14 April}

Office. Welsh Bachellery. Only Raude was there. Mme Desportes must have given up. I don't blame her!!! I think that I have a cold coming. Gosh, it is warm. "Extraits choisis" (Péguy). Cut the first bunch of flowers from the garden. Stocks, a daisy with daisy, violet and daffodil leaves, everything in a little blue Delft pot on the radio. It looks pretty. Tonight there's firing going off all over.

377 François Mauriac (1885-1970). French Catholic novelist. Le Noeud de vipères was published in 1932. See the website dedicated to him here: http://francois-mauriac.aquitaine.fr/flash.htm

${ }^{378}$ Harry Baur (1880-1943). For a potted biography of French actor Baur, his film career and the circumstances surrounding his death, read the entry on page 40 of Dayna Oscherwitz and MaryEllen Higgins's 2009 cinema encyclopaedia, The A to $Z$ of French Cinema (Lanham: Scarecrow Press).

${ }^{379}$ Film directed by Marcel Carné (1906-1996). See Jonathon Driskell's 2012 study of Carné, Marcel Carné, in the French film directors Manchester University Press series for more on Carnés creative activity during the Occupation.

380 'catty' written in English in the manuscript. 
Very worried. Still not had news from Dad, Mum. I can't get it out of my head that they are dead. - the Germans must have gone into the Free Zone at the end of November/December. If Mummy had realised then she'd have written straightaway - though I wouldn't have a message before end of April, beginning of May, true. So, pointless tormenting myself about it. Mme Desportes took her painting to the Salon.

\section{Thursday 15 April}

Office all day. Lesson with Gilberte Frey who'll be finishing lessons at the end of the month. I'm astonished that she has carried on for so long with them. I will have to replace her. Where can I get money from? Lesson with Chabert. He gave me some work for tomorrow. I went to bed at 3.30 am and still hadn't finished. Gave the radiator to the electrician who had come to repair Madeleine Fortan's lamp. Jacqueline Piatier came to chat, to tell me that I should go be a class tutor. It is tempting. I've had enough of the office and of Kort. I'll have to speak to Vendryès. I

\section{Friday 16 April}

Finished work for Chabert. Irish with Vendryès. The poor man is overwrought. Spoke to him. Nothing before October but thinks that it is a certainty. ${ }^{381}$ Office. Lesson with Dick. Wrote to Aunt. Telephoned Soulié who wasn't there. Very annoying because still not paid and no money - I really need to buy some shoes, my token expires tomorrow. I want to have an early night because for ages I have been going to bed early in the morning. Mended jacket. 11.05? Air raid warning. didn't hear the all clear. I

\section{Saturday 17 April}

It really was pounding away at around $4 \mathrm{am}$. It woke me up. What beautiful weather it is. A flower flowered in my garden. Going by the number and size of its leaves I thought to myself "It'll be a beautiful marigold!" Woe - the yellow floweret is the size of a press stud......

Between 4 and 5 went with Maggy Desportes to the Luxembourg. ${ }^{382}$ The weather was radiant. All the chestnut trees are in flower. The fullness of their leaves makes it seem like midsummer. It is a shame that there aren't any pink chestnut trees. I remember the one at the convent, in the corner reserved for the nuns. A pink rain

${ }^{381}$ This may be a reference to round-ups of 'foreign' students, expected after they were made to register their names. Or it may be a reference to the STO (Service du travail obligatoire), compulsory work service.

${ }^{382}$ Luxembourg Gardens. 
falling from it onto the nun, dressed in black and white, reciting the rosary below. I remember her being like a statue. Oh, if only I could sit on a lawn.

Bought slippers with token. I quite like them. Bought some lilac for 20 francs out of the 60 francs I had left. Am I always going to be this mad? It is mauve and smells divine! It's a bit parched and looks a bit sorry for itself but already, after half an hour in water, it is standing more proudly and sending out its scent into the room. Now that's a flower that makes an excellent and elegant arrangement without having to do too much with it. Letter from Mme Faure asking me for student tickets for "Pepys". What next? She says that she has news from Germaine. Will it be long before I have news from my parents? Went to speak to Jacqueline Piatier in evening.

Went to "Lissa" the milliners opposite, to have my hat brim reshaped. She was worried about how I made a living. When she found out that I got 1200 francs she said to me "You need a man to support you" (!!!) Went to the tailor to find out how much the making up of the jacket would cost - 850 frs. I don't think that I can have one that it wearable. Confession. Air raid warning in the night. I.

\section{Sunday 18th April}

Communion. Mass. Did the housework. 10.15-11.20 air raid warning. Maggy Desportes came when I was in the middle of the housework. She admired the view and the apartment. Mad.F came to wash her towels in my basin. She went to a chic marriage yesterday. Asked the youngest sister (18 years old) of the bridegroom 'What do you think of your new sister in law?' - 'She looks like a virgin' (the modern girl '43). Darned. Listened to the "Damnation of Faust", but the "Chevauchée infernale" was interrupted by the Lent sermon. Pity. I love the "Damnation" especially the "Hungarian March" "Voici des roses" and the bit before it where Méphisto calls the sylphs, "Le Roi de Thulé" and the "Chevauchée aux Enfers". Dilys came at 11 o'clock to bring eggs (6 were broken - out of how many??) but more particularly to try to get tobacco and to moan that $\mathrm{SB}^{383}$ no longer goes to see her (private suggestion not for saying out loud - perhaps SB has finally realised what Dil is (?)). Woke up twice in the night because it was pounding away so loudly. The second time, heard flak shrapnel bouncing off the roofs and crashing onto the road; but this morning there wasn't a trace although there was a lot of police. Beautiful moon after a hot and sunny day. I.

\section{Monday 19 April}

Rain. Office. Denise wants a storm "If it thunders in April, get out the water butts". She had her wish granted by this afternoon's storm. My word the rain is

383 Sylvia Beach. 
good. One can see that the flowers are happy about it, they look all perky and they have grown - something which all our watering hasn't managed to make happen. The cactus got a good soaking, their spines shining like tiny ivory pins. Had lunch at the house. Forgot that I am on the 4 th day of Nico. ${ }^{384} \mathrm{Had}$ to swallow an aspirin hurriedly but didn't go lie down. Made a hand flannel and a hand towel. Went to Chabert's but he wasn't there. Saw Dilys in the street. This morning I saw a barrage balloon going off freely into the sky. It looked like a big fish swimming way up high. The chestnut trees in the Val de G are blossoming - I saw two roses in the Luxembourg, Very happy. I have at last located the bird that sings so well. He perches on the chimney of number 326 (there isn't a 324) and, with his head towards the sun, he sings. Goodness me, doesn't everything smell wonderful when it has rained. The greens of the $\mathrm{V}$ de $\mathrm{G}^{385}$ are fantastic. Inside two blackbirds form a duo. Theirs is the last song before nightfall. There are only soft sounds. One can feel the peace of the evening drawing down over ones worries and, showing no mercy, extinguishing them all under such a pretty veil of calm. It is still too light for the houses on the horizon to become "my hills and my woods" and the real hill is encircled in mist like Fugi-Yama. ${ }^{386}$ The blackbird has found a very pretty tune; he has another go at it, switches and comes back to the first refrain. Such peace!!

My little wild stock plant is funny. Little Miss will only open up for the sun. Once evening comes, or the rain comes or even a big black cloud, quick, quick, she closes up. Even the prettiest rose would not look after its little self so carefully.

Lights come on here and there. In the workers' block, a $25^{\circ}$ turn from here on the 7th floor, a black silhouette stands out against the light. It gets colder and everything goes dark. I am going to close up, the news has come on so all the more reason. ${ }^{387}$

Today I saw the little girl (Henriette, 14 days old) who belongs to the Concierge at the Centre de Documentation at the BN. She is chubby and beautiful; mum is horribly tired. Went to bed early $(10.30 \mathrm{pm})$ in order to get up for $6 \mathrm{am}$. Can only use 6 kilowatts per month - so have to keep a close eye on the meter and use daylight as much as possible - but what a change in routine!! Denise pulled out my first grey hair!!!! I

\section{Tuesday 20 April}

Woke up at 6 am. Did some darning. Office all day - too fed up for words. It looks like we will be moving down to the main room - in that dust-caked

\footnotetext{
${ }^{384}$ Nico short for Nicodème, Madeleine's name for her menstrual cycle.

385 Val de Grâce.

386 Fujiyama.

387 This may be a reference to listening to illegal broadcasts from the BBC (Radio Londres).
} 
icebox. How awful. Maggy Desportes phoned but I couldn't understand what she was saying and so I sent her a pneu. Had lunch at the office. 1 hardboiled egg, 2 little cheeses (a ticket for each one). 100 gr of bread and butter, 2 lumps of sugar. Quality if not quantity and it kept me going until 9.30 pm when I managed to get rid of Mad. Fortan who stayed for an hour and 15 minutes making me miss the news. Lesson with Dick. Dropped by to see Maggy - her picture is being shown at the Salon. Great. Wrote to Mme Faure. Telephoned Soulié who doesn't seem too worried about paying me for my voucher. The hawthorn is in flower - it smells divine. There's a laburnum too. It is colder today though. I.

\section{Wednesday 21 April}

Office. Soulié telephoned - I'll get paid by The Musicians Union at last. Swapped a litre of wine for 2 eggs. Light but persistent rain. Went to the Musicians Union. Waited for Maggy Desportes at Luxembourg then had tea with her. Her husband is very nice. Tired. Very hungry. I've gone over my bread ration but I need to eat something. I've still had no news from Mum.

\section{Thursday 22 April}

So terribly tired, woke up at $7 \mathrm{am}$ ! Wanted to open up the thumb in the yellow glove I am knitting and so didn't manage to do gym exercises and got up at $8 \mathrm{am}$. Washed and dressed, did hair, made snack for lunch in 10 minutes. Goes without saying that breakfast went by the by. Office all day and had lunch there ( 2 hard boiled eggs, $100 \mathrm{~g}$ of bread and margarine, 2 lumps of sugar). Was poisonous with Bertin-Conrad but with good reason. He doesn't do any work. Disappears for two hours or an hour and a half - and me and Denise aren't allowed to open so much as a book (in the office at Ecorcheville, Saulet and Hartz are allowed to study as much as they like). What's more, Denise and I have to do the registering of new files. We have to manage on our own but we have to help out' Bertin-Conrad - in other words, we have to do his work for him. I moaned non-stop. Kort and Duret thought it was hilarious. I want to smash everything up. In October, I may well leave.

Took cigarettes to Dilys who gave me potatoes and sold me 4 eggs. She doesn't suspect that I am making 45 francs on her fags. She is very nice with me - she is doubtlessly going to ask me to do something.

What abundance - jam, pasta, tins of peas, pulses!! (I'm spoilt, but not all months are like this). We're getting much better supplies in this year - and I am starting to "get myself straight" - cf: Gilberte Frey's parents will send me things. Tried on my dangly earrings this afternoon and they suit me a treat! It is frightening to see now that I am pretty after having spent nearly 25 years thinking that I wasn't. If only I had some money - alas. But, no point complaining about it. I am getting by quite well despite the poor pay from the office. The lessons save the day. Tired. 


\section{Friday 23 April}

Got up late. Office in the afternoon. Good Friday. Lesson with Dick. Letter from Aunt telling me to come stay for two days. Went to see the Easter alter at St Jacques du Haut-Pas.

\section{Saturday 24 April}

Office. Letter from Marguerite Delplanque:

My dear Miss Blaess, ${ }^{388}$

I hope, Miss Madeleine, that my letter will meet you in good health.

My letter will be short because I find my words with difficulty.

It will learn to you that I am well and chiefly that I enjoy myself very much.

Can I confess to you that I did not still begin the exercises you have given to me.

All the day long I walk with my cousin Suzanne on bicycle or on foot. This day I have clean the house of my grandmother. So, this evening I am tired.

I hope that you, yourself are well.

Perhaps you will have a few moments to write to me.

I expect and hope your letter and writing I pray you to want to admit with my good wishes for Easter, the best friendships of

Marguerite

Worked.

\section{Sunday 25 April}

Easter. Mass. C. Housework. Took the radio to Dilys (couldn't hear the church bells from home this morning because of the wretched interference - I wept about it) Villeparisis with Aunt. Yo, Marcel, Aimée, Huguette. Played together. M. Labère came over with Armande and ? Zinzer. They haven't yet come to terms with the marriage of their son. "Signé illisible". ${ }^{389}$ Fun.

${ }^{388}$ The letter was written in English and reproduced in English by Madeleine in her diary.

3891942 film by Christian Chamborant. 


\section{Monday 26 April}

Marcel left early. Visit Jeanne Pelletier with Jean and Simone. Brought back lilac and iris.

\section{Tuesday 27 April}

Office all day. Waited for Dick who didn't come. Got paid anyway. Still no news from Mum. Worried, very worried. Took back the radio from Dilys. Dilys sulked.

\section{Wednesday 28 April}

Office. Lesson at $1 \mathrm{pm}$ with Dick so didn't have the time to have lunch. Scoffed a sandwich at Marcuisot. Spotted Soulié with a young woman. Went to Hôtel de Ville to see Fontoblia. Got a leek. Posters. Saw Cécile Péchegut. Collected food ration cards. Had lunch and dinner all together when I got back.

\section{Thursday 29 April}

Office all day. In the morning I helped Madame Chaillon shelve the books in the basement. Bertin-Conrad called me "pig headed”!! Last lesson with Gilberte Frey "L'Appel du Silence" ${ }^{390}$ V. good. Since then I have been in the Hoggar mountains. Wrote to Marguerite Delplanque.

\section{Friday 30 April}

Wanted to get up at 6 am - to do the washing and to distribute the posters - but alas, got up at $9.30 \mathrm{am}$. Worked. Office. Got paid. Joined the American Library. "The Axe" (Sigrid Undset) ${ }^{391}$ "The Vita Merlini" (J.J Parry). ${ }^{392}$

\section{Saturday 1 May}

Bought lily of the valley which smells very nice. Worked all day. Letter from Aunt. Still nothing from mummy. This time, very, very worried but think that

3901936 French film directed by Léon Poirier. The story of Charles de Foucauld. See: http://www.unifrance.org/film/8517/l-appel-du-silence

${ }^{391}$ Sigrid Undset (1882-1949). The Axe is one volume of a fictional tetralogy about medieval Norway.

392 John Jay Parry's translation from Latin into English of Geoffrey of Monmouth's Life of Merlin. 
there is a 'freeze' at the Red Cross. ${ }^{393}$ Perhaps she can only write after one of my messages? I need to send one, double quick.

\section{Sunday 2 May 1943}

Mass at the Val-de-Grâce. The chapel is awful - contorted, over-ornate, gilded. It echoes loudly. In a corner there is a beautiful painting. Went to Aunt's - who was charm itself. "Une femme dans la nuit" with Vivienne Romance ${ }^{394}$ - daft but VR is very beautiful. Aunt gave me 4 eggs, leeks, potatoes. Mended Yo's stockings Marcel broke a tile. Brought back my doll's set. Very pleased about that. It is prettier than I remember. There was also a doll's tea service and a doll's washroom set. What a shame that Dad took Claire ${ }^{395}$ back home. I would have had her now. The rain is terrible. The night is black - lucky that I can find my way back from the Odeon with my eyes closed because I couldn't see anything at all.

\section{Monday 3 May}

Put posters up. Got soaked to the skin. Paid the gas and the electricity. Impossible to get warm again despite tea and rum. Terribly hungry. Heard the clock of the Panthéon strike 10 o'clock. It has such a pretty sound. Conversation with Cécile Péchuget, I don't want to go out with her on Sunday in the slightest. Worked on my Irish. Mad. Fortan came over. Long conversation. Dilys came with me - to check out the lie of the land for the cigarettes. Georges and Gaël are back tomorrow. Today I had beer instead of cider at the Centre. $11.45 \mathrm{pm}-$ air raid alert?? Was asleep.

\section{Tuesday 4 May}

Gave ration cards to Jacqueline Piatier - she is getting married at Pentecost. Housework. Fixed my shifts. Since Saturday I have been wanting to get up early, and I have been waking up at 8.30-9 oclock!! Oh who cares it is the holidays. Might as well make the most of it before having to get back to the grindstone. Got a message from Chabert to give me urgent work to get done this evening. That's fine. It is silly but an unexpected ring at the doorbell and my legs give way from under me and I shake for a quarter of an hour afterwards. ${ }^{396}$ Went to Chabert at 1.30 to fetch the translation. Did some work on it. Went to bed at $3.00 \mathrm{am}$.

\footnotetext{
393 No mail getting through at the Red Cross.

3941943 film directed by Edmond Gréville. Vivienne Romance (1912-1991) was one of the most famous French actresses of the day. See: http://www.unifrance.org/film/37103/une-femme-dans-la-nuit

395 Claire is the doll, presumably.

396 A rare insight into how frightened Madeleine is that she will be arrested.
} 


\section{Wednesday 5 May}

Got up at 5 am (2 hours sleep!) Translation. Went to Bachellery's class. Horrible because Maggy Desportes left straight away to go to a preview at the Salon and so I was on my own with Bachellery. It was painful. He was sad because he no longer has any pupils. In the end an old fellow came in the evening. Translation. Cécile Péchegut came over - I made her tea. She was charmed and charming. Told me that Brémaud had been thrown out - he had asked for 3 days off like Dax had been given and just like Dax he came back smiling all over his face 10 days later. It was happening too often. Cécile Péchugut had managed to find him a job as a security guard at a museum but he snootily refused manual work. He'll do alright with his cinema, the black market and his crocodile tears which he turns on to get the sympathy of his chums. CP told me that he couldn't even make an alphabetic list nor write an address on an envelope properly. Deep down, she likes "our friend Brémaud" as she is fond of saying. But I am pleased he has lost his job; in my opinion he was stealing his pay. He'll probably end up in prison - let's say he can't help it, that he is retarded, a dimwit, or whatever. "He is romantic" says CP "and that's how to take him". Take him by the belly and by the - more like! That's a big digression for such a little man. Let's bury him. Nice weather.

Dilys made a brief appearance with Gaël, who has whooping cough, to bring me three eggs. Translation. Upset. Spoke with Mad. F then was very, very tired. I lay down fully dressed for

\section{Thursday 6 May}

an hour - woke up 3 hours later at $6 \mathrm{am}$. Typed quickly and finished just in time. Took the work over. Went round the market, bought a pansy to plant in soil and anemones for the vase. Very pretty but too tired to be wildly admiring of it. Upset when I got back because I couldn't see my cacti on the window ledge but the gutter cleaners had been by and moved them to a place of safety. Dead tired -6 hours sleep in 48 is not enough. Rain. Françoise Boësse came over. Slept 3-6 pm and from 9 pm.

\section{Friday 7 May}

Irish with Vendryès. Darned. Started to type up Merlin. Lesson with Chabert. Hail. Showers.

\section{Saturday 8 May}

Bought ticket for the National Lottery - the ticket sellers earn 2 francs per ticket. Violent rainstorm. Typed from Parry's "Vita Merlin". Went to Françoise Boësse's who gave me butter. Her two room flat is just what I need - I am totally 
jealous. Damn!! Lunches have gone up by 2 francs per meal - that will cost me 60 francs extra a month. Annoying. Letter from Cyla. Went to see "Dernier des Six" ${ }^{397}$ - queue - and no room so came back. Tunis and Bizerta taken. ${ }^{398}$

\section{Sunday 9 May}

Mass. Just as I was setting off to get the train for Villeparisis there was such an enormous downpour that I stayed here. Ate like a Queen: Onion omelette (2 eggs), Rum crêpes, tea. Feel sleepy. Worked on thesis. Started cardigan with unpicked wool because I won't have enough to make another jumper, the ersatz navy blue wool kept snapping all the time and was therefore useless. Spent a nice afternoon looking for a pattern. Result: I'll make it my way.

\section{Monday 10 May}

Office. Before leaving here I opened the window as I do usually and went to the kitchen to fetch some crumbs. A cheeky sparrow came to wait for me to come back. Bertin-Conrad is the happy grandfather of a little girl Catherine who was born yesterday. But it was pretty horrid that the parents hadn't even told him that they had gone to the clinic. He was all emotional at the thought of being a grandfather (it's the 2 nd time. What must have it been like 1st time round?) Met up with Mlle Péchegut who gave me some beans. Denise brought mushrooms. And there's me thinking I have nothing to eat. In the evening I ate the beans in a veal trotter gravy and a mushroom omelette. In the afternoon I worked for 4 hours. I did the washing (a big wash). Tired out. Strong wind - several times I was worried for my pot plants. Pneu from Fontablia.

\section{Tuesday 11 May}

Office all day. Sent another pneu to Fontablia. Went by Hôtel de Ville to collect the posters. Lesson with Delplanque and Chabert. Got a very nice letter from Aunt. Threw away the veal trotter. Horrible. I don't like that, it makes me feel sick. I thought that I had done a good job of cooking it. Ate roast beef. I dare not think about my budget. Mad. F in the mood for talking but I sent her away

\footnotetext{
3971941 French film directed by Georges Lacombe.

398 British troops captured Tunis on May 7, 1943. American troops captured Bizerte 'the last remaining port in Axis hands'. Axis forces surrendered on May 13, 1943. See the United States Holocaust Memorial Museum's entry on the North Africa campaign: https://www.ushmm.org/wlc/en/article.php?ModuleId=10007304
} 
because I wanted to have dinner before my lesson. Worried that I might have annoyed her. Cold but not raining. $10 \mathrm{pm}$. Washing nearly dry.

\section{Wednesday 12 May}

Office. Had lunch here. Put up the posters. Welsh with Bachellery. Tea with Maggy Desportes. Had dinner with Giselle du Mesnil. Saw her dog which is horribly thin. Not very cold. Got up at 6 am to do the ironing.

\section{Thursday 13 May +}

Office all day. Had lunch at the office. Finished "Vita M." by Parry. Went to the American Library. Waldren (Thoreau) ${ }^{399}$ “The Jackdaw's Nest"400 (?) 4-4.50 pm. Got caught in an air raid alert at Etoile. Walked to the Red Cross, waited in front of the door. When the alert was over I wrote a message to Mummy. "All is well here but a long absence of news from you. In good health. Marcel hopes to go to visit Charles and Gaby. André is well. Hugs to all". Waited 3/4 hour for the bus. The sun was beating down. I? The métro only started up $3 / 4$ of an hour after the all clear - huge queue and crowd. Bought my first cherries: 17.50 per pound ${ }^{401}$ (they used to be 15 and 18 francs per $100 \mathrm{~g}$. Same thing for strawberries, 19 and 20 francs per $100 \mathrm{~g}$ ). Dilys came over because of a row and she really needed to speak to Georges alone. Between 9 and 11.30 pm I went to look after Gaël and her grandmother. It was impossible to work because Mrs Evans was moaning on, doesn't get on with Georges and spoke non-stop. Did some emergency sewing until 2 am. Washed hair. Dry in quarter of an hour!! Found 50 francs in the métro.

\section{Friday 14 May}

Lesson with Vendryès who was charming. Office. Got a 100 franc bonus for the work I did clearing out. There are rumours that there won't be any holidays!!! Very hot. Telephoned Fontablia. Went to Hôtel de Ville for the posters. Beans have all gone off. Went to see Chabert but he wasn't there - he had said that maybe he wouldn't be. In a bad mood, all the more because I have to go to Aunt's at the weekend (such a nice letter that I can't refuse) Does she not

${ }^{399}$ Henry Thoreau (1817-1862 ). See Robert McCrum's appraisal of what British newspaper The Guardian describes as one of the best non-fiction books of all time:

https://www.theguardian.com/books/2017/apr/24/100-best-nonfictionbooks-walden-henry-david-thoreau

${ }^{400}$ Possibly by Gerald Bullett (1893-1958). A 'five-fold anthology' published in 1939 (various sources).

${ }^{401}$ Unclear in the manuscript. Looks like 'livre'. Madeleine alternates between metric and imperial weights. 
understand that it is the only day that I can spend at home?? Letter from Soulié about checking tickets at the concert tomorrow night. Absolutely exhausted with tiredness, by the heat, by Nico. Didn't work. Started Walden - amazing. Had to throw out my beans - they'd gone off and had to finish my meat which was starting to go mouldy.

\section{Saturday 15 May}

Office. Went to Confession. Did the tickets at "Jeunesse et Musique" rue Cardinet. J. Soulié was charming - he noticed (at last?!?!) that I had had my hair cut. The concert was good. 5-6 air raid warning. Half an hour Lesson with Chabert. Very curt pneu from Aunt.

\section{Sunday 16 May}

Villeparisis. Roger was there. Brought lots of things. I had a quarter of butter because he'd said so but Aunt was furious about it. I asked him to send me a parcel knowing that he would refuse. Aunt glared at him and he did just that. Aunt had made herself up and dressed very smartly, putting on little airs and graces. Tch tch!!

\section{Monday 17 May}

Office. Worked. Took posters. Tired out. Letter about National Insurance.

\section{Tuesday 18 May}

Office all day. Was late so there was a bit of bother. Lesson with Dick, Chabert no Delplanque.

\section{Wednesday 19 May}

Office. Finished distributing the posters. Welsh with Bachellery who was charming. $11.30 \mathrm{pm}-1$ am air raid warning.

\section{Thursday 20 May}

Office all day. Went to see Vendryès but he wasn't there. Madeleine Lavelle, Dilys and Jacqueline P visited. Wrote to Cyla. Hot. Tired. Bought "Sacra Famiglia" by Luini. Happy.

\section{Friday 21 May}

Irish with Vendryés who was charming. Had a long conversation with him. Superb paintings in his office. Office. Hot. Lesson with Dick and with Chabert. 
There is going to be a storm. I feel so heavy and tired. Unsettled. Not happy. Impossible to work. Can't concentrate.

\section{Saturday 22 May}

Office. Boiled the washing and waited for it whilst knitting but I fell asleep. Confession. Priest was fed up - and my knees hurt from being knelt down on wood. Bought strawberries. Eggs arrived. Made an omelette flambé with strawberry jam. Don't feel right. Ill. Appendicitis. Bought "Montaigne" (Villey) ( $^{402}$ and "Tristran et Iseult" (Bédier). ${ }^{403}$ Got out "Refuges" (Léon-Paul Fargue). ${ }^{404}$

\section{Sunday 23 May}

Mass. C. Dilys came over. She wants me to hire a radio. ${ }^{405}$ Finished the gloves. Lay down all day knitting and reading. "Walden" (Thoreau) full of important truths but the style is heavy going. Ill. Burning pain in the side. Dots in front of my eyes. Dizzy and have a headache. Listened to the 2 nd concert of the Beethoven cycle. Liked it a lot. Cool and dull day.

\section{Monday 24 May}

Tired. Office. Mme Maréchal is having a baby in August. Did the washing with the woollens too. Very heavy rain after strong winds. Arc of a rainbow right in front of me. All I needed to do was to jump out and go underneath it to get into the Beautiful Country. I would love a house in the country. Dilys came over to tell me that she is being lent a radio. She's got whooping cough. She wants something, but what? She hung around for a bit, paid me a few compliments and then went off.

${ }^{402}$ Pierre Villey's doctoral thesis Les Sources et l'Évolution des Essais de Montaigne submitted to the Faculté des lettres de l'Université de Paris and published by Librairie Hachette in 1908. For more details and a digital copy, see: http://gallica.bnf.fr/ark:/12148/bpt6k66607q

${ }^{403}$ Retelling of the legend by Collège de France academic Joseph Bédier (18641938). For a full scan of the Piazza edition, see: https://archive.org/stream/leromandetrista00bd\#page/n9/mode/2up

${ }^{404}$ Léon-Paul Fargue (1876-1947). Refuges was published in 1942. For more on Fargue see (in French): http://republique-des-lettres.com/fargue-9782824902708.php

${ }^{405}$ Possibly hire a radio for Dilys. As a British citizen, Dilys was not allowed to own one. 


\section{Tuesday 25 May}

Office all day. Didn't go for lunch at St Louis but ate snack in the office instead. Bibli. Américaine. ${ }^{406}$ "The Little Girl and other Stories" (Katherine Mansfield). ${ }^{407}$ She writes very well. Such youth, such freshness, such powers of evocation. Lesson with Dick, Marguerite and Chabert.

\section{Wednesday 26 May}

Office. Ironed 6 to $7.30 \mathrm{am}$. C Péchegut brought round the barter for the wine. ${ }^{408}$ Sent packaging to Frey. Requested birth certificate. Welsh with Bachellery. Hôtel de Ville. Token from Soulié. Bought potatoes which I sauteed. Glorious! - There's a change.

\section{Thursday 27 May}

Office all day. Went to Victor Massé to get my pay. "Marie-Claire" (Marguerite Audoux $)^{409}$ Bought $1 \mathrm{~kg}$ of strawberries!!! Ate the lot with yoghurt. What a greedy guts - but I rarely buy myself treats - and I had convinced myself that they cost only 8.50 per pound (and not per quarter).

\section{Friday 28 May}

Went to collect food ration book. Welsh with Vendryès. Office. Got paid. Lesson with Dick. Letter from Aunt. She is jealous that I am seeing Dilys. Dilys came round with 6 eggs. She is charming at the moment. What does she want? Hot.

\section{Saturday 29 May}

Office. Came back tired out from the Salon where I'd been to see Maggy Desportes' paintings. The Salon was pretty insipid on the whole. There were

406 The American Library was founded in 1920 and was open throughout the Occupation. See the American Library's website for more on its history: https://www.americanlibraryinparis.org/about-the-library/history-of-thelibrary.html

${ }^{407}$ Katherine Mansfield (1888-1923).

408 'échange vin' in the manuscript. Could refer to the goods Madeleine has bartered her wine rations for, or possibly, empty wine bottles for refilling (and possibly the return of a deposit).

${ }^{409}$ Marguerite Audoux (1863-1937). The novel Marie-Claire was published in 1910. 
some beautiful portraits, some splendid roses by Etchevarry, three stirring skyscapes by Pierre de Clossade ${ }^{410}$ and three beautiful canvases by Ivanoff. There was a tapestry portrait and several Richelieu motifs which Mum could have thought up and done. So many steps and such heat! Breeze and trees at Trocadéro were very pleasant. My hats aren't ready yet. For over a week there hasn't been anything in Paris and for three days not even anything with which to make a salad. Nothing is getting through. We're eating pasta again!! It's a reprisal for the three German soldiers killed on the rue de Courcelles a few days ago. Dilys brought me 6 eggs. I wonder what she wants?

\section{Sunday 30 May}

Mass. C. Mother's day. Villeparisis with Aunt, Yo, Marcel. Bathed in the River Ourcq. First time since 1938? 1936?

\section{Monday 31 May}

Office. Lesson with Chabert.

\section{Tuesday 1 June}

Office all day. Lesson with Dick, Delplanque. A new arrival at the office, a Madame Félice. Ugly. Says that she is a teacher but she sings at the cabaret.

\section{Wednesday 2 June}

Dilys brought 6 eggs! No kidding!! What does she want from me? Lesson with Chabert. Brought back pulses to cook. Looked after Danielle La Berrie 2.30 til 6.30. She is still strapped into her cot!! Got a carton of eggs: 7 cracked, 3 missing and 2 alright!!

\section{Thursday 3 June}

Ascension Day. Mass Cooked beans. Had lunch at Madame Laberrie's with Chabert. Tired. Illish. ${ }^{411}$

${ }^{410}$ Both painters' surnames misspelt by Madeleine. Etchevarry should be Hubert Denis Etcheverry (1867-1950) and Clossade should be Pierre de Clausade (1910-1978).

411 'Illish' written in English in the manuscript. 


\section{Friday 4 June}

Welsh. Last lesson with Vendryès. Sweet adorable. ${ }^{412}$ Told me to go and see Monsieur Humbert (his son in law). Office. I really do not like Marcelle Félice. Brought up in Algeria. Has she got Algerian blood?? No lesson with Dick today. He's going away on business.

\section{Saturday 5 June}

Office. Lesson with Chabert ( $3 / 4$ hour). Got wine for Mad. Fortan. Went to do the tickets for the 6th and the last "Musique et Jeunesse" concert (Ecole Normale Supérieure de Musique). Brémaud came. He was furious that Mademoiselle Péchegut had not told me that he had gone away - hardly worth a lie. Came home early.

\section{Sunday 6 June}

Mass. C. Depressed. Cried. Slept. Darned. I am not living. I just sleep and dream.

\section{Monday 7 June}

Got copy of birth certificate - backdated a month. Lesson with Chabert. Marie Blot telephoned. Dédé has hurt his foot. Voirin has written about the money he sent me for the burial? I am furious. Why not write to me about it? Went to Dilys to get the books (stayed there $1 / 2$ an hour). Darned. Dilys came over. Stayed 3 hours!!!! Depressed. Office.

\section{Tuesday 8 June}

Office. St Médard. Rain. Dressed up smart because depressed (white flannel blouse with a brooch in rose gold) and made myself up. Went to the Coop on the rue de Richlieu with Mademoiselle Kerjean for work. Got some cherries. Lesson with Dick, Delplanque.

I'm so depressed, tis true

I'm leaving then, but where to?

I won't write a word more

Still alive in August or dead before? ${ }^{413}$

412 'Sweet adorable' written in English in the manuscript.

${ }^{413}$ Car puisque j’ai un cafard fou; Je vais partir je ne sais où; je nécrirai plus rien du tout; Vivrai-je encore au mois d'août? 
(Scribbled that on a bit of paper at $10.30 \mathrm{pm}$ with no light in bed). I have eaten too many cherries (1 pound). My stomach hurts a bit. Office all day.

\section{Wednesday 9 June}

Office. Welsh. Bachellery. Wrote to Aunt. Brought back gainko. ${ }^{414}$ Walk with Maggy Desportes.

\section{Thursday 10 June}

Office all day. "Testament of Friendship" (Vera Britten) "Picture of Dorian Grey" (Oscar Wilde). Homesick. I adore Winifred Holtby. Went to the Red Cross. "This long silence drags on. Asking for news right now, even if bad. Family, friends all well. Still working, studying very little. Hope for an improvement on the work front before too long. Hugs and kisses'.

Dilys is very depressed. She came to mine. We went to the "Closérie des Lilas". Orangeade. The hats aren't ready.

\section{Friday 11 June}

Went to the hairdressers. Saw Maggy Desportes. Office. Sent a pneu to Denise because no office tomorrow. Telephoned Denise. She'd left her exam after $1 / 2$ an hour. Got the hats. Very happy with my red one. Parcel from Monsieur Zéau, beans etc.

\section{Saturday 12 June +}

Got up late. Letter from Aunt. Lazy. Unhappy. 3 lessons Deirdre. I.

\section{Sunday 13 June +}

Pentecost. Mass. Villeparisis. I

\section{Monday 14 June +}

Lazy. Went to St Denis. Went to see the fortune teller but she wasn't there. I

\section{Tuesday 15 June +}

Lazy. Bought a thing for my legs - but didn't go to see Humbert because ill. Lesson with Dick. Delplanque.

${ }^{414}$ Possibly Ginkgo plant although spelt Gainko in the manuscript. 


\section{Wednesday 16 June +}

Office. Rain and as it was Chabert's lesson he lent me a raincoat. "Les Chemins de la Mer" (?). ${ }^{415}$ Went to see Dilys. Welsh with Bachellery. Went to St Denis. Pneu from Beaujean. Telephoned Beaujean. Went to the fortune teller. [Will be told of a pregnancy or a birth. Change on the work front which will be better from all points of view. Death of a young soldier from my family in an accident. I'll be told by letter. News and money from my father. In about a year, I will be travelling abroad or to the colonies where I will settle. Marriage with a civil servant who is very well off and older than me. My father will be there to meet us both during the night at the end of the journey. I must beware a jealous widow and someone in her entourage who will try to pinch my civil servant. Mum worried about an inheritance. I am too much of a mug.]

\section{Thursday 17 June}

Office all day. "Testament of Youth" (Vera Brittain). ${ }^{416}$ "The Edwardians" (V.Sackville-West). ${ }^{417} 3$ lessons with Dudu.

\section{Friday 18 June}

Met Beaujean. Café. Mlle Komatsu (Japanese woman). Saw Maggy Desportes and Humbert does not take visitors in the morning. Office. Humbert. Lesson with Dick.

\section{Saturday 19 June}

Office. Went to Dilys's (she's passed études pratiques and Philology). Went to the 'Great Exhibition of the French Family' in the Mairie in the 5th arrondissement. Gave the toilet a thorough clean. $10.45 \mathrm{pm}$. It isn't dark outside.

\section{Sunday 20 June}

Mass. Sewed 10th patch into sheet. Started to alter the clothes rail curtain. 2-3.30 pm. Air raid warning.

415 By François Mauriac (1885-1970). The novel was first published by Grasset in 1939.

416 Published in 1933. Elizabeth Day's 2013 feature in The Guardian is a useful introduction to Brittain and the background to the writing of Testament of Youth:

https://www.theguardian.com/books/2013/mar/24/vera-brittain-testamentof-youth

417 Vita Sackville-West (1892-1962). 


\section{Monday 21 June}

Office. First lesson with Beaujean. Charming. Sent off packing for the parcel. Pneu from Mme Faure.

\section{Tuesday 22 June}

Office all day. "Mandoa, Mandoa" (W.Holtby). ${ }^{418}$ Lunch. Went to the Parc Monceau. ${ }^{419}$ Lesson with Dick and Delplanque. Shelled the peas. Had dinner at $10 \mathrm{pm}$. Alert from 1-2 am.

\section{Wednesday 23 June}

Office. Had lunch at the Parc Monceau. 100 gr of bread. Made up the hour I had taken to see Humbert - there was no need but Kort didn't say anything - the pig!! Last lesson with Bachellery. He is clingy. Saw student arrests - horrified. Went to Madame Faure's for the language records. Had dinner at Madame Faure's listened to Georges Thill, Yvonne Printemps, Ninon Vallin, Sacha Guitry ${ }^{420}$ and "Chant du Désert". Spoke a lot about my family.

\section{Thursday 24 June}

Office. Lunched on 100 grams of dry bread. Office all day. Lesson Dudu. Went to Dilys to tell her about the arrangements for Bachellery. Had dinner. Got back at 12.30 pm!! "Week-end Book". Good. Had photo done for work permit.

${ }^{418}$ First published in 1933. See Lisa Regan's entry in the Literary Encyclopaedia: https://www.litencyc.com/php/sworks.php?rec=true\&UID=3752

${ }^{419}$ Paris park in the 8th arrondissement just off the Boulevard de Courcelles.

${ }^{420}$ Georges Thill (1897-1984) was a French opera singer and tenor. Read John Rockwell's obituary in The New York Times:

http://www.nytimes.com/1984/10/18/obituaries/georges-thill-is-dead-at86-was-famous-french-tenor.html.

Yvonne Printemps (1894-1977).

See page 218 of Richard Traubner's Operetta: A Theatrical History (2004) for more about Printemps' career in opera and music hall. Ninon Vallin (1886-1961) was a French soprano. There is little background available in English about her other than Andrea Suhm-Binder's fan site:

http://www.cantabile-subito.de/Sopranos/Vallin__Ninon/hauptteil_ vallin_ninon.html.

Sacha Guitry (1885-1957) was a French playwright, actor and director. See here for more about his life and career:

https://www.britannica.com/biography/Sacha-Guitry 


\section{Friday 25 June}

No lesson with Komatsu. Lesson with Beaujean. I'll know all there is to know about judo! He is sweet. Set ball rolling for papers etc. Dick didn’t come but will charge for his lesson. Read until $1 \mathrm{am}$ !

\section{Saturday 26 June}

Office. Bought shoes, buttons etc. Since Tuesday students have not been allowed in the Luxembourg gardens. Had tea at Maggy Desportes' place. She and her children were good cover in the Luxembourg. Went to give a bedpan to Mrs Evans but was forced to stay so stayed ${ }^{421}$ from 6-12.15 pm. Didn't have dinner. Wasn't offered anything. Sewed on the buttons and ribbons. Charming pneu from Aunt.

\section{Sunday 27 June}

Mass. Tired out. Just about cleared the kitchen. Almost passable. I just have to clean it from top to bottom. Wrote a long letter to Aunt.

\section{Monday 28 June}

Office. Lesson Beaujean. Pneu from Aunt inviting me to dinner Tuesday evening. Dinner with Dilys. Wanted to see "Volpone" 422 but didn't go. Ended up going to "Chateau des 4 obèses". ${ }^{23}$ Daft. Got a parcel from Portugal (2 packs of almond figs). Great. Went to the Red Cross "Very pleased to get the parcel. Huge thanks. Don't worry. I am in excellent health despite not being able to study. I still haven't had any news from you. I think constantly about you. Hugs and kisses".

\section{Tuesday 29 June}

Office all day. Telephoned Aunt. She is coming tomorrow!! Lesson with Dick. Delplanque. Housework til $3 \mathrm{am}$. Cleaned kitchen from top to bottom. "Truth is not Sober" (W. Holtby), "England their England" (A.G Macdonell). ${ }^{424}$

\footnotetext{
${ }^{421}$ 'so stayed' in English in the manuscript.

4221941 French film adaptation of Ben Jonson's seventeenth-century play directed by Maurice Tourneur and starring Harry Baur: http://www.telerama.fr/cinema/films/le-chateau-des-quatre-obeses,471020.php

${ }^{423} 1939$ French murder mystery film directed by Yvan Noé. For information about plot and casting (in French) see: http://www.telerama.fr/cinema/films/le-chateau-des-quatre-obeses,471020.php ${ }^{424}$ A. G. Macdonell (1895-1941). The novel, a social satire on the English way of life in the inter-war years was published in 1933.
} 


\section{Wednesday 30 June}

Got up at $5 \mathrm{am}$. Washed the floor and the floorboards. Office. Went to the Portuguese Consulate for parcel. Went to the Red Cross to acknowledge ${ }^{425}$ parcel. Aunt came. 7-8.10. Liked everything. Went to Chabert's for nothing. Gave me mouldy butter.

\section{Thursday 1 July}

Office all day. Lesson with Dudu for 3 hours (waited 11/2 hours). Foot hurts.

\section{Friday 2 July}

Lesson Mlle Komatsu. Beaujean. Doctor's appointment St Antoine. Air raid alert 4.45 to 5.15. Casier Judiciaire. ${ }^{426}$ Lesson with Dick. "The White Hare" (Francis Stuart). ${ }^{427}$

\section{Saturday 3 July}

Office. Paid electricity. Bought "Mabinogi" (Loth). Slept. Typed.

\section{Sunday 4 July}

Mass. Went to see Dilys who asked whether going out today could be put off until tomorrow evening. Typed. It is hot. "Sortilèges exotiques" - nice scenery but that was it. In the Rue Soufflot I heard a German soldier say "What is that house" - "Le Panthéon".

\section{Monday 5 July}

Pneu putting Marguerite Delplanque off until later. Office. Telephone call from Beaujean who can't come for his lesson. Denise is very close to becoming Guy's mistress. Got a very kind letter from André. Lesson with Madame Endeville.

${ }^{425}$ The word 'acknowledge' is written in English in the original manuscript.

${ }^{426}$ Casier judiciaire is evidence of a criminal record - or absence of one.

${ }^{427}$ Novel published in 1936. Francis Stuart (1902-2000) was an Irish novelist. He lived and worked in Nazi Germany during the war, was arrested by the Allies but later released. Accusations of Nazi sympathies surrounded Stuart both before and after his death. Colm Tóibín's 2001 feature on Stuart in The London Review of Books (a review of Stuart's wartime broadcasts from Germany) is balanced and well-informed:

https://www.lrb.co.uk/v23/n01/colm-toibin/issues-of-truth-and-invention 
Dilys not at all well. Making no sense. Pneu from Delplanque who can't come because she is tired. Our pneus must have crossed.

\section{Tuesday 6 July}

Office all day. Lesson with Dick, Delplanque. Message of 10 May for Mummy: "Don't lose faith or heart despite the lack of news. Everything is fine. Health is excellent. Happy that everyone is doing well. Much sadness about uncle's death. Tender thoughts. Hugs. Mummy" "Old Wives Tale" (Bennett). ${ }^{428}$ Very good. "Mon Repos" (Nicholas Bevel). Daft.

\section{Wednesday 7 July}

Office. Lesson with Madame Endeville. Two hours done inadvertently. "Forgot" to go to the office to cover on Friday afternoon (had a doctor's appointment).

\section{Thursday 8 July}

Office all day. Lesson with Dudu. Cécile Péchegut came over. Tired out. ${ }^{429}$ "Family History" (V. Sackville West). "Androcles and the Lion" (+"Overruled" + "Pygmalion") (Bernard Shaw). ${ }^{430}$ Met up with Roland. Yo has passed.

\section{Friday 9 July}

Lesson with Komatsu. Beaujean. Office. Lesson with Dick who was with his friend Mark who was in the BEF. ${ }^{431}$ Dilys is depressed and came to get me to go to the cinema for "Chasse à l'Homme" (German film). ${ }^{432}$ So so. It was raining when we came out and my ersatz jacket has shrunk!!! Radioscopie in the office.

${ }^{428}$ Arnold Bennett (1867-1931). The novel was published in 1908. See Charlotte Jones's 2016 feature on the author and novel in The Guardian:

https://www.theguardian.com/books/booksblog/2016/jan/01/the-oldwives-tale-by-arnold-bennett-an-extraordinary-story-of-ordinary-life

429 'Tired out' written in English in the manuscript.

${ }^{430}$ George Bernard Shaw (1856 -1950). Irish playwright and Nobel Prize in Literature winner for 1925 . See the Nobel entry here:

https://www.nobelprize.org/nobel_prizes/literature/laureates/1925/shawbio.html

${ }^{431}$ BEF is the acronym for the British Expeditionary Force.

${ }^{432}$ It would seem unlikely that this 'Chasse à l'homme' is Fritz Lang's 1941 antiNazi film about a thwarted attempt to assassinate Hitler. However, there appears to be no other film by that title in France's cinemas at the time. Is Madeleine's reference to 'German film' a reference to Lang? 
Full of awful bodies!!! Wrote to Aunt. Michael annoyed me with his romantic trials and tribulations.

\section{Saturday 10 July}

7.45-8.50 am air raid warning. The English have landed in Sicily. Tired out and down. Letter from Cyla but not a pleasure to read.

\section{Sunday 11 July}

Mass. Tired out. Illish. ${ }^{433}$ Slept from 2.30 til 5.30 pm. Copied up diary. Sieved flour.

\section{Monday 12 July +}

Office. Fine weather, close in the morning. Rain. Lesson with Mme d'Eudeville and afternoon tea (buttered toast and jam, peaches, fresh figs). Went over to Françoise Boësse's. Had dinner there. Came back at 10.30 pm. At 11.15, loud doorbell ringing. It's Dilys. She has lost her key and can't get in. In the end, at 11.30, Madame Bergen's key worked. Marcel is leaving for Carenton. I

\section{Tuesday 13 July +}

0.15-0.45. Air raid alert. Stupid, because the bombing had more or less finished by the time the first sirens were screaming out. Butter had gone very off. So, it seems we will have a month's holiday!!! Lesson with Dick. New moon.

\section{Wednesday 14 July +}

7.45-8.50 air raid warning. Renaud ${ }^{434}$ got hit. 80 bombers were visible but stood on the rubbish chute I was mistaking flak smoke for planes when they were going in front of my window. Read, rested up. Holidayed. "Bring 'em Back Alive (Frank Buck) ${ }^{435}$ “The Eternal Moment" (E.M.Forster) ${ }^{436}$ Went to meet Beaujean at Louis-le-Grand ${ }^{437}$ but it was all closed up. Came back via the rue

${ }^{433}$ 'Illish' in English in the manuscript.

${ }^{434}$ Means Renault factories in the suburbs.

${ }^{435}$ Frank Buck (1884-1950). Bring 'em back alive, a book about the author's game-hunting experiences, was published in 1930.

${ }^{436}$ E.M. Forster (1879-1970). Short stories published in 1928.

${ }^{437}$ Louis-le-Grand, famous sixteenth-century lycée (secondary school) on the rue St Jacques. 
Sommerard ${ }^{438}$ but he wasn't there. Thought that would be the case. Feel a bit sluggish and have a headache. But that is how I am all the time. When will I no longer have to drag this $100 \mathrm{~kg}$ weight of mine around? When will my head feel clear and alert? Very hot. My cockscomb destroyed by the heat. I.

\section{Thursday 15 July +}

Wrote to Aunt but forgot to put the letter in the post. Office but so dreadfully poorly. I. This is the fourth day in pain. Nico, + nauseous. Left eye is running and vision blurred and everything is spinning. Came back to the house (it took me $1 \frac{1}{4}$ hours instead of the usual $3 / 4$ of an hour). Went to bed. Slept. Too hot. When I wanted to get up my heart started to beat like a piston or a water pump. Big waves of red before my eyes, I've never had that before. It eased off later. Roast veal from Bléneau. No lesson today (Denise sent pneus). I hope I can manage to replace them so as not to lose money. 4.50-5.10. Alert. Got up in order to get food in. Everything is spinning. And still this silly wanting to cry which has hounded me all day. Letter from Aunt. Overjoyed because Yolande passed the exam and will be getting a permanent job. Amazing, she's going to be able to have a pension. Feel catty - but I am counting my blessings. ${ }^{439}$ She has set herself up before me - but I don't want to be a civil servant and I don't want to settle in France. So, what I'm feeling isn't logical particularly given that amazing job that awaits me when (when!) I get my doctorate. If only my head wasn't so empty and not up to studying. If only I didn't feel so terribly poorly. Cheer up duckie. ${ }^{440}$ Tomorrow, you will feel better. I.

\section{Friday 16 July +}

Lesson with Beaujean. Went to the Sorbonne for copy of certificates. Office. Still wonky ${ }^{441}$ so straight home. Had to give a lesson at Ranelagh at $9 \mathrm{pm}$ but air raid alert from 7.50-8.55. Mad. F talked for a long time then Cécile Péchegut came. Decided to go out to Montfort l'Amaury. What a pain. I hate going out so much. Sent pneu to Aunt. Went to the Comtesse d'Eudeville's but no lesson. Very hot. I

\section{Saturday 17 July}

Office. Still wonky. ${ }^{42}$ Since Thursday my left eye has been streaming. Went to Dudu's. Saw M. Pietraru - a senile old boy!! He is at least 40 years older than

\footnotetext{
438 Rue de Sommerard.

439 'Feel catty' and 'blessings' written in English in the manuscript.

440 'Cheer up duckie' written in English in the manuscript.

441 'Still wonky' written in English in the manuscript.

442 'Still wonky' again written in English.
} 
Mme Pietraru. Shattered, Very hot. Mad. F insists on talking. Mme Tiffernan is expecting a baby!!

\section{Sunday 18th July}

Didn't go to mass. [...] Went to get potatoes but couldn't. Bought some peaches for granny's birthday. Villeparisis. Aunt, Yo, Aimée, Huguette, Nicole. Nicole is pretty with brown curly hair but she does not shut up. Huguette sat on lap in the front. Nicole is still sucking her thumb - at 5 and a half years old!! Hot. Astonished at myself because not at all jealous of Yo. She is earning 1,900, the same as Aunt, and with her qualifications could go up to 2,500. Pension too. At last she's got a job. Praise the Lord!! Impossible to find food - brought back a pound of green beans. Hot, hot, hot.

\section{Monday 19th July}

Office. Marcelle Félice fainted and Kort caught her in his arms!! Lesson with D'Eudeville and Beaujean. Queued for $3 / 4$ of an hour to get the train times for Montfort l'Amaury on Sunday. Sent card to granny. Pneu to Mademoiselle Barland. Went to Dilys's to tell her that I could not go to dinner. Marcelle from St Denis visited Madeleine F. We get on very well. Washed blouse. Paid for the meat from Frey thought I had 50 francs worth - but 90 francs including delivery!! Never again!!

\section{Tuesday 20th July}

Office all day. No lesson with Dick. "Five Red Herrings" (Dorothy L. Sayers) ) $^{443}$ Lesson with Mademoiselle Barland. She's been to America. Sweet. ${ }^{444}$ Sent a birthday card to granny. St Marguerite

\section{Wednesday 21 July}

Office. Lesson with d'Eudeville. Invited Françoise Boësse for a cup of tea and she stayed from 4.35 until 9.45!!!! She never knows when to go but she is nice. Cécile Péchegut came over. Denise brought peaches for my birthday!! "My Life" (Isadora Duncan). She was such a Zazoue!!

${ }^{443}$ Dorothy L. Sayers (1893-1957). A British writer of crime and mystery novels and like a number of Madeleine's preferred inter-war women novelists, a university arts graduate. Sayers studied French at Oxford. See her biography on the Somerville College web pages.

https://www.some.ox.ac.uk/about-somerville/somerville-stories/dorothy1-sayers/

444 'Sweet' in English in the manuscript. 


\section{Thursday 22 July}

St Madeleine. Got a card off Aunt and Madame Faure. Office all day. Dudu lesson but left 5.30. Flappée dead. Pneu from Barland telling me not to come tomorrow. Cyla came!! and brought roses for my birthday. Was very surprised but didn't show it. She has put on a lot of weight and has filled out a lot. She is very much the matronly figure. I didn't know what to say to her. I think that I would have preferred not to see her because she is no longer her. No two people ever grow in the same direction. I forgot to invite her to dinner because I was so stunned by the surprise of seeing her. She invited me round on Thursday. I hope that she cancels. "Fin Isadora Duncan" (Mary Desti) ${ }^{445}$ Isadora more zazoue than ever.

\section{Friday 23 July}

Lesson with Beaujean. Office. I have never been so bored - nearly cried out of boredom and sadness. Never, NEVER, NEVERRRRRRRR, do I want to stay in this office. I won't be here in October - tutoring or no tutoring. Unhappy, sick. Down, no desire to work. "The du Mauriers" (Daphne du Maurier) ${ }^{446}$ Not bad. Humanity disgusts me. At the moment what I need is:

1. An iron fist to make me work and to which I can stand up to.

2. Someone with whom I can argue whilst remaining a good friend.

3. A very romantic love affair.

\section{Saturday 24 July}

0.10 - ? Air raid alert. Office. Cécile Péchegut came. We decided not to go to Montfort-l'Amaury tomorrow because of the unsettled weather. Had lunch at $2.30 \mathrm{pm}$. Copied up diary. Went to Cécile Péchegut's and decided not to go to Marly tomorrow. Met up with Renée Desprès who will be taking an exam on aesthetics on Monday. Talked with Mad. Fortan. I must sort myself out. I spend too much time talking to Mad. F, sometimes 3 hours. It's mad. But, we are unhappy both of us and so we talk. She is a great girl, very full of herself but very simple in her ways and direct. She'd tell me to go to Hell if she felt like it. We're comfortable with each other because of this - there's just the

${ }^{445}$ Mary Desti (1871-1931) was a close friend of dancer Isadora Duncan. Her biography of Duncan was published in 1929.

446 Daphne Du Maurier (1907-1989). A useful introduction to the life and work of Du Maurier is The Daphne Du Maurier Companion, a collection of short essays and anecdotes about the author published in 2007 and edited by Helen Taylor. 
conversation problem I am stuck with. 9 pm. Françoise Boësse came over with butter and stayed until 11.10. She is nice. So many visits and visitors!! And still this inertia - heaviness in the legs, incessant pain in the eyes and head. Not hungry but I need to eat all the same, but I am off food. I would like to learn:

1. Red Cross. First Aid

2. French and English shorthand

3. How to drive a car.

4. Learn German

5. Learn how to spin thread.

It would be fun to do this in August but what about my exam?

\section{Sunday 25 July}

Mass, housework, copied up diary. Did several bits of mending. Did ironing. An autumn day today, grey sky, misty, cold. It's like September. Lots of energy for once, how did that happen? Made some delicious crêpes with the sieved flour, 1 egg, rum, powdered milk.

\section{Monday 26 July}

Mussolini resigned!! Yaow yaow, yaow. The Italians are buggered!!! The Germans have put wire mesh over the Speiselokale ${ }^{447}$ on the Boul'Mich and doubled the watch. Lesson with Mlle Barland. No lesson with d'Eudeville. Lesson with Beaujean.

\section{Tuesday 27 July}

Office all day. "This was my World" (Lady Rhondda). ${ }^{48}$ Very good. "The Volume of Ghost Stories" (?)

\section{Wednesday 28 July}

Office. Went to get paid at $2.30 \mathrm{pm}$. Lesson with d'Eudeville in her husband's parlour. So many pretty ornaments. Lesson with Barland. Very hot. Went to the hairdresser.

${ }^{447}$ Café/restaurant for the German military.

${ }^{448}$ Margaret Haig Thomas Mackworth (1883-1958) was a suffragette and feminist campaigner. This was my World was published in 1933. 


\section{Thursday 29 July}

Office all day. Had lunch in the Parc Monceau - in the shade and with the sprinklers in front of me. Wrote to Aunt. Dudu was not there. Dropped in at Dilys's who lent me "Murder off Miami" (Dennis Wheatley). ${ }^{449}$ Nicely presented. Went to Colette's and had dinner with Cyla. All talked rubbish - awful! Cyla has changed a lot. Giselle du Mesnil came to the office. Went to the station to find out time of train to Montfort l'Amaury.

\section{Friday 30 July}

Went to see Mademoiselle Péchegut who wasn't there - ill. So, we won't be going out on Saturday. Hooray!! ${ }^{450}$ Bought potatoes. Lesson with Beaujean. Ate grapes - exquisite. Last afternoon in the office - then it is the holidays! Hooray, hooray. Mlle Haillon is 40! I didn't think that she was so old. Note from Denise - poor kid. Lesson with Barland, late. Telephoned Madame Pietratu (Marion Dorianne) twice. Paris $51^{\circ} \mathrm{C}\left(124^{\circ} \mathrm{F}\right.$ ?) Hot.

\section{Saturday 31 July}

Slept very well - amazing given how hot it is. Am wearing swimming costume, because I am baking hot. 11.30-12.5 air raid alert. Copied up diary. 2.30-5 slept a bit. Heat is oppressive. Letter from Aunt. Went to Dilys's. Confession. "The Little Man Murders (?) Ruth Camp came to borrow the typewriter. She annoys me. Couldn't sleep. Sent card to Godfather.

\section{Sunday 1 August}

Impossible to sleep. 1-2 am. Put the concert on the radio. Got off at $4 \mathrm{am}$. Woke up at 7 am Mass. C. Villeparisis. Knitted. Hot. Fight in the train coming back. Aunt was called a nutcase. I don't think she's could believe it.

\section{Monday 2 August}

Housework. Ruth came to give the typewriter back. Went to Dilys's. Rain. Pneu from Giselle. St Alphonse. Housework. Went to Denise Pedron's for dinner. She was charm itself. Her mother is a vixen. ${ }^{451}$

${ }^{449}$ Dennis Wheatley (1897-1977). Murder off Miami, a crime mystery, was published in 1936.

450 'Hooray' written in English in the manuscript.

451 'vixen' written in English in the manuscript. 


\section{Tuesday 3 August}

Clothes washing ( + a sheet ${ }^{452}$ ). Went to Dilys's place for my first ever manicure. Not bad. I have pretty nails now. Did some ironing. Lesson with Barland. Huge storm.

\section{Wednesday 4 August}

Pneu to Giselle. Peeled the beans I'd been soaking to make bean soup. Housework and very worried ${ }^{453}$ about the cooking for dinner this evening. Denise came at $6 \mathrm{pm}$. Admired my view. Introduced her to Mad. F as well as to Giselle when she came. Alert between 6.15 and $6.40 \mathrm{pm}$. Made dinner. Bean soup (exquisite - though I says it as shouldn't) ${ }^{454}$ fried potatoes but Denise's pan sticks and so, as Denise said "from time to time one comes across them nicely cooked". Jam and rum omelette, grapes. The dinner was a huge success. Giselle and Denise loved my room. Denise was tearful when I had to throw her out at $9.30 \mathrm{pm}$ but the time it'd take her to get to L'Odéon would mean she'd never be home by 10.30 !! Giselle came back up. Talked at the window as the sun set and then went with her to Denfert for her last métro. It was a very successful evening. Spoke to Mad Fortan until $1 \mathrm{am}$.

\section{Thursday 5 August}

Mad F went on holiday. I went to the market. I love markets. Cyla came to have lunch at $1.30 \mathrm{pm}$ because she thought that the testing of the sirens was a real alert!!! Sausage (brought by Cyla) fried potatoes (exquisite today) and beefsteak, tomato salad, grapes, tea with rum. At last I have found my Cyla, a really wonderful girl. Stayed until $4.30 \mathrm{pm}$ because I had a lesson with Dudu. Cyla is annoyed and disappointed with Ruth Camp. That doesn't surprise me. Cyla admires the huge changes in me and thinks I am the perfect housewife. I am pleased about that. Françoise Boësse flying visit ${ }^{455}$ to give me back "South Riding" and to invite me to lunch on Saturday, annoying but I accepted anyway. Lesson with Dudu - not him, his brother Riquet who is a splendid man and very courteous. He learns English with dizzying speed. Weather very unsettled, rain.

\footnotetext{
${ }^{452}+$ is usually a reference to menstrual cycle in the manuscript. This may mean soiled sheets.

453 'worried' in English in the manuscript.

${ }^{454}$ 'though I says it as shouldn't' in English in the manuscript.

${ }_{455}$ 'flying visit' in English in the manuscript.
} 


\section{Friday 6 August}

Housework. Remembered with horror that I had a lesson with Mlle Komatsu at $10.30 \mathrm{am}$. Flew out. Lesson Mlle Komatsu - very tiring because her Japanese brain does not get things in the same way as we do and it is necessary to explain even the simplest thing using examples and details. Finished - at last! - copying up diary. Rain. Tired. Battling tiredness. All I want to do is sleep. I should be studying, darning or knitting. These things are more pressing. I am cold. Amusing letter from Maggy Desportes. At 8 pm I saw a marvellous rainbow, right in front of my window right over the Val-de-Grâce. The right side went right down in front of the trees at the Val-de-Grâce and gave the leaves an extraordinary tint and ended in a little outhouse. The other leg stretched over the Chapel. It kept its splendour for several minutes, a double arc encircling it timidly, and then it paled and it retreated into the distance, into the sky where I'd never be able to reach it. I have never seen one so close. If the Val-de-Grâce was accessible to mere mortals I would have climbed down into the rainbow and bathed in its colours, I would have become a fairy. Continual rain. It is cold. Lesson with Barland. It is a long way out to Ranelagh. On the way back I was falling to sleep in the métro. It is annoying, it is $11 \mathrm{pm}$ before I get back. The nights are not that dark yet.

\section{Saturday 7 August}

Woke up late after an extraordinary dream about a man who was dying in a chapel and he knew that he was dying because his likeness was already engraved on the family tomb. The priest gave him the communion wafer but he returned it in the form of a white stone. The tomb opened slightly and the dead from his family in both Hell and Heaven each demanded his soul. He had committed a crime, a young girl of 25 years of age, all white, in a white dress. She came out of the shadows and he took her in his arms once again as he had done on the fateful day but when they got to the ravine, he didn't let her fall but held her tightly. Thus he was saved and while they all went to get the priest (where had he gone?) the man was buried alone by invisible hands underneath the bronze plaque which was still bearing his picture. Dahlias and gladioli were thrown and I put gypsophila everywhere. Then the scene changed to a moorland ${ }^{456}$ village where there was a girl who was going to get married.

The meter reader for the electricity came. I've gone over by 3. Rain. Went for lunch to Françoise Boësse's. She is very nice but I really have to rack my brain to find something to talk about with her. Left to her own devices she is practically dumb. Having silences does not scare me with people I am close to but with her I worry that it is impolite. We went to the Jardin des Plantes, a pretty

456 'village des moorlands' in the manuscript. 
garden but very poorly maintained. We went to the Musée d'Histoire naturelle. Bones, bones everywhere. I think that I was the most impressed by the whale carcass. It is enormous. It gave me the shivers. It is strange that a mass of bones could make me feel like that. Afterwards, the Diplodocus, the Mastodon, the Mammoth left me cold. It the first time I had seen them but I couldn't believe that they were real. They looked too plaster-like to me, strange. The Diplodocus has an absolutely huge tail and the last vertebrae in its tail is miniscule (about $5 \mathrm{~cm}$ ) set against the big bones of the animal. I liked the fossils a lot and I was pleased when I recognised a specimen from afar. There should be someone there to explain all these things. Downstairs there was an extraordinary collection of tongues - although the moulds or preserved specimens are as horrible and unrealistic as the real insides are adorable, delicate. I didn't like looking at the monkey parts. They had a suffering in their expression which made me feel bad. I must go back to the Jardin des Plantes. There's not a lot of people and the flowers are nice - but it is a long way away, too far for me to drag myself and I don't feel like going out at the moment, Tea at Françoise's place. She lent me "Mr Proback (Arnold Bennett), ${ }^{457}$ "Les Eaux Printanières" (Tourgénieff?) ${ }^{458}$ and "Le Journal de Marie Bashkirtseff". 459 So, naturally I read "Mr Proback" until 2 in the morning whilst eating a kilo of grapes without even thinking about it. This vice I have is terrible, because a vice it is. When I don't read I really get through a lot of work, be it intellectual work or practical work. When there is something to read, the house could fall down around me and I wouldn't be able to stop. It is worse than opium (I would guess) If the book is there, I won't do anything else until it is finished and the housework and everything else falls by the wayside. That and my "procrastination"... I don't have many other faults. I can control them, overcome them but these two vices will ruin my life for me I fear. What can I do to sort myself out?

${ }^{457}$ Arnold Bennett (1867-1931). Mr Proback was published in 1922. For more on English writer Bennett and another of his famous novels, The Old Wives' Tale, read Charlotte Jones's 2016 feature in The Guardian:

https://www.theguardian.com/books/booksblog/2016/jan/01/the-oldwives-tale-by-arnold-bennett-an-extraordinary-story-of-ordinary-life

${ }^{458}$ Russian novelist Ivan Tourgueniev (1818-1883). Eaux printanières was published in 1871. The English translation, Torrents of Spring, was published in 1872.

${ }^{459}$ Marie Bashkirtseff (1858-1884) was a Ukrainian writer and painter who settled in Paris at the end of the nineteenth century. Her diary was well known in student circles and much admired by Madeleine. Bashkirtseff's diary is available via the digital collections of the Bibliothèque nationale at: http://gallica.bnf.fr/ark:/12148/bpt6k1131377 


\section{Sunday 8 August}

9.55-10.35 am Air Raid sirens so mass at 11 am. Made a grape tart. Very good it is but not having any yeast, it was a bit heavy. Started to read 'Le Journal de Marie Bashkirtseff'. What an honesty about her. I blush when I compare my diary to hers - but there is a difference between the two in that Marie intended that her journal be read by the general public and I am just wanting mine to help me remember everything later on. When I am writing, I have a constant fear that someone will open it - at customs, I don't know, which stops me putting down everything I think and feel. I hope that I will remember when I read things which appear to be insignificant. Memory is a powerful thing. I want it to follow the traces I am leaving, prompted by the vaguest hints that no one else will be able to see. But, at the moment, I don't really feel an awful lot. I am less numb, certainly, than I was in August 1940 for example, but I feel that I am waiting. My life now is no more than a pause, a stop between two stations. The more I read about the period after the last war, the more I am shamefully pleased that things got back to normal so quickly. I can't listen to the radio announcements urging me to serve or help recruit. I feel 'out of it'. ${ }^{460} \mathrm{I}$ haven't done anything to speed up the end of the war. I've only fought a battle to survive, to not die of hunger and mental exhaustion. I have not fought for others. I have had to fight alone to survive. Those who love me are too far away. I don't even have the comfort of fighting shoulder to shoulder for something better against an enemy. For me, the enemy is hunger, cold, the lack of money. If I were to die one evening no one would notice except my mother and father. The few words of regret uttered after news of my death would be swept from the memory in quarter of an hour, at most, by a social gathering or else hand-outs of pasta. Prisoners are able to say: 'I fought. I was beaten but, all the same, I paid my dues to the country'. I can't say any of that. Nothing. 'What did you do during the war?' 'I tried not to die of hunger.' What a brave and heroic response. Enough now. I have, nevertheless, learnt how to live a bit and I have not built my life on the misery of others.

Until the age of 20: "Don't get too close, you might get burnt."

Now: "A big [...] $]^{461}$ and true love" But, alas! Neither one nor the other seem to be on the horizon. I need to find some willpower-! I don't have any. What can I do to get some. It is such a beautiful day outside but no willpower to make me go out. Slept from 4 til $7 \mathrm{pm}$. It was a mistake because tonight I will be 'as wide awake as a mouse" as Mad. F says but I still feel this need to sleep which makes me wonder how I stayed wide awake when I was young. More than anything I am plagued by Nicodème which doesn't come and which makes me ill, which causes me to have funny turns. I may well go out this evening for a walk?

460 'out of it' written in English in the manuscript.

461 Unclear but could be 'tache' which means task. 
10-11.15 pm. Went for a walk - my old shoes from England. God how good they feel, I could have walked the night through. Went to the Bd de Port-Royal, Bd. St Marcel, Bd. de l'Hôpital, along the banks by the Jardin des Plantes and the Halle aux Vins. The moon was out, lighting up Notre Dame. I crossed the Seine to walk in front of its gate - its 3 doors which are like three mouths wanting to eat up the square in front. It made me think of an old print of a mystery play where Hell had a huge devouring mouth the same 3 doors of ND, but a holy place - although those doors do not look very holy to me at night. Went along the banks on the other side of the water to see the moon behind the Temple (?) (the prison that runs alongside the Seine). Its many pointy roofs - the arrow of the St Chapelle, all of it black against the moon and a river of diamonds in front. Oh, it's so beautiful, particularly when seen from the side. Face on it seems flat, like a theatre decor. Maybe I am terribly romantic. I don't care. I have always loved the great dark cathedrals sparkling in places under stained glass, the alter a lake of golden light from the candles, the arches invisible and [. . . $]^{462}$ in the incense smoke and the little white chapels where sand crackles in the wind which smells of kelp and tar and where, perhaps there is a little dusty model boat given in thanksgiving moving slightly from side to side with a creaking sound like that of the red lamp, the only animate shape against the white and the brown. I fell asleep and had an awful dream. I hadn't finished my studies and father didn't want to lend me the money to finish my degree and to do my thesis. Mum was weeping and I went to see about financial support from the government and was promised a grant of $£ 40$ a year on condition that I lived at the Franco-British College. This only covered the rent and I said that I would have to give language lessons but that would mean that I could not finish in a year. It really upsets me to have a thesis which is barely started and these classical literature studies which are like a slow-acting and painful poison. I flinch from them just as I would in front of a chasm I have to jump into. At the same time, it is just hard, boring graft. I need to get down to it. If only I had someone here to encourage me, meaning mum or if I felt that I was competing, that'd be better. I am dying to do my thesis but I want to finish my degree first. There is no point having 36 things on the go especially given that I am so interested in my thesis that in comparison Etudes Litt seems all the more insipid and even someone standing over me with a whip wouldn't make me get down to it.

\section{Monday 9 August}

I wanted to be a saint and work from 9 am-12 am this morning but I had to do some urgent repairs to my bed sheet and that took me absolutely ages to do. Anyway, I decided that morally the holidays were over for me and that I would work (study) 8 hours a day. I hope I have the energy to do that!! I still

${ }^{462}$ possibly 'bleues', blue in the incense smoke. 
feel very sluggish and peaky because of Nico which is late. Drizzling. Knitted. Worked myself silly with 6 hours at one go on Tacite. Gave myself $1 / 2$ an hour to translate 10 lines of the Annales but remembered that it was les Histoires that needed doing. I set about reading the translation of the Annales to give myself a start. Feel sicky. ${ }^{463}$ Cécile Péchegut came with some tomatoes to borrow some potatoes but I don't have any more. I may even have to buy some on the black market if I don't get a ticket from somewhere soon. Read Marie Bashkirtseff's diary. Françoise Boësse thinks that it is crackers. I don't. It's a girl who knew that she didn't have long to live and knew that she had a role to fulfil. Aren't we all the same? I felt very strongly that I had a mission between 18 and 19 . Even if now I do not feel that as strongly it is because I feel that the walls of my prison are too high for now - I believe that it will take another one or two years before I can show what I'm capable of. I know so little about anything. I am so abysmally ignorant - and my writing style!! How can I write with such an awful style?? I have to rid myself of some staid ideas.

A moment ago the sky above me was beautiful, grey then blue, white clouds with grey undersides, pink with light grey clouds like smoke, edged with fawn and then mauve. Then it became like a pigeon plumage but in pastel, now it is grey, grey-blue and white. And the dome of the Val-de-Grâce stands out with its flesh-tinted stone and roof of greenish-blue metal. Gosh, it is so pretty. In the evening when the sun lights up the buildings in the distance the shadow of this building hastens nightfall over half of Paris. So many people must curse the building which deprives them so quickly of the setting sun. I am perched so high that nothing takes the sun away from me in the morning and in the evening I get it a little round the back. So there is a teaching conference at York? I had a pang when I heard that and shed silly tears. Where is the conference? I can think of three or four halls but perhaps it is in none of them. Will there be people I know there? This could well make me very depressed indeed. When it comes down to it I get attached to people or things far too much and being separated from them makes me suffer terribly. And I joke around and laugh so that no one suspects anything. Lots of my acquaintances are duped by that.

I stayed sitting on the window sill with my feet in the window box, I was looking up at the sky and suddenly a star shot through a gap in the clouds like a tiny spark from a blazing hearth to fall amongst a rich mass of velvet. I waited for more stars. It was fun because there was only the sky and clouds and then suddenly, without knowing why, a star would appear. They seemed to be shooting so very quickly above my head. Later on, we were back to having just clouds again.

463 'Feel sicky' written in English in the original manuscript. 


\section{Tuesday 10 August}

Went to the market. Huge queue for tomatoes and I was out of tickets. Other than tomatoes there was nothing except some beans "which rabbits would break their teeth on" said someone behind me. Bought nothing. I had to register for fruit and vegetables with number 13 coupon from the half-year ration card. Poor us. It is horrifying now. But it is silly to sign up now, everyone is on holiday. I am being increasingly forced to use the black market but I would rather do that than go to a restaurant. It is still less dear and I have nothing to eat. I also know what I am eating.

Very pleased with myself. Worked for 3 hours on Latin; 4 hours on French and later I'll be giving some private lessons. That will make up my 8 hours. I don't know whether it is the climate or what but I think that I have got back the person I was four years ago - what optimism, what enthusiasm, what confidence in myself. But, physically, I am not good. Went to have a manicure round at Dilys's - who is jealous of my pretty nails. I must be careful. She has set out the bedroom nicely. But the kitchen - Good Lord - what a disgusting mess - It has never got as bad as that at my place.

This afternoon a fellow at the Val-de-Grâce started to scream and to cry. It was terrible, so terrible. It lasted 5 minutes. They must have given him something; - but to think that someone can suffer so much!! It was barely human. It was heart wrenching. Poor fellow.

Lesson with Mlle Barland. She knows one of Vendryès's sons. Drizzle. 11.2512.20 air raid siren.

\section{Wednesday 11 August}

Awoke still very sleepy. Hardly surprising because the flak guns hammered away all night non-stop!!!! What I like is when they sound an air raid alert there is absolute silence but when there isn't one that's when all Hell breaks loose!! It started at 2.30 am with the sky all lit up with flashes. At 4 am the house began to tremble, my bed shook me around like a rag doll. You could hear the shrapnel falling on the roof. At $5.30 \mathrm{am}$ I got up to have a look because the noise was so loud and didn't stop. It was like 20 storms all at once with thunderclaps coming one after another without stopping. I could only see flashes from my bedroom window. From the kitchen it was like daylight because the explosions lit everything up and came so quickly one after the other. There must be an anti-aircraft gun nearby. It wasn't the one at St Michel. Wrong direction. I've never felt the building shake like that before. The weather is closing in menacingly, as if the flood is on the way (I dreamt that I was in a submarine).

Studied my Latin for 4 hours - I can't do more than 4 hours at one go because It tires me out. So, knitted a bit before leaving for the lesson with Dudu. Went to the Red Cross. "Was absolutely delighted to receive message. Yol. got into the Civil Service. I am on holiday. How are Aunt Marguerite, Joan, Margaret, Nibs, 
Sammy? Do send me news, especially yours. Health is excellent. Love". Got soaked in the rain. Went to Dudu's but got the day wrong. It must have been Friday. Françoise B coming to lunch! I sent her a pneu to put her off. Letter from Mad. F and Giselle who have put me off until Saturday instead of tomorrow. That suits me better. Today, my 8 hours of work plan went well, because I did four but what about the other four? It is $18 \mathrm{~h} 30$ and I want to listen to "Pygmalion" in French on the radio this evening. I would rather ${ }^{464}$ do it tomorrow. I've had two heels ripped off my little red shoes. Goodness, I am so tired!!! And I have spent so much money unfortunately. I must go carefully now but I haven't spent unnecessarily so what can I do? Listened to "Pygmalion". Well translated - but I didn't really like the adaptation.

\section{Thursday 12 August +}

Slept like a log until $9 \mathrm{am}$. It is 9.30 and I am already starting to feel extremely poorly. I'm wrapped up, in the sun, trying to see off the poorliness without having to go to bed. I want to work. Pity, I think I can only manage one more hour. Stayed in sun and felt sick but wasn't. Did some French. Between 11 and 11.20 there was an alert. Afterwards I made myself do a past paper for 2 hours . It was pretty demanding and I am wiped out I have to say. So can I not do this studying anymore? - I have done 6 hours of intensive study. Montaigne this afternoon, but that's ok. I am [. . .]. After a rest (?) I did the crossword whilst eating grapes, am still as tired. It is 7.15 and I still have two hours study to do probably a little exercise or something because my brain is no longer working. Is 8 hours too long? I've just got to organise myself, Didn't have to go to bed because I kept myself extremely warm. Good thing to know. Finished the back of my ribbed cardigan. It looks elegant. 11.15-11. 50 alert. I think that the Piatiers are back - just as well that I went to pick up their linen. I

\section{Friday 13 August}

Was woken up again last night at around 3.30 because of the flak. But I was so tired that I fell back to sleep immediately and don't know whether it carried on. Oh, I am so tired!!! Wrote to Aunt Violette, André. Had lesson with Komatsu. Lesson with Dudu. 5.30-5.40 alert. Mme P says that things are just pitiful in Berlin. They have told them to stand tall just like the English did when they were in danger of being invaded. Haven't been paid yet for the month of July. I need to ask. Letter from Aunt Violette and a word from Françoise B. Such a nice letter from Aunt that I had a few regrets about having said I would not be there for the 15th August because of Nicodème. She will never understand

464 'rather' written in English in the manuscript. 
what a joy it is to be alone. She is going to be angry but never mind. If Nico had come the day after I still wouldn't have gone, it is true. I read something very good about the love of solitude in the literary reviews section of "Panorama". It's Roman Fernandez speaking about "A la recherche de Marie" (Madeleine Bourdouxhe). ${ }^{465}$ "Marie, Jean's wife" he says "is, in fact, a presence first and foremost, a silent presence. . . . she is both a woman of the home and a wanderer, loving her husband but with routine intimacy (a tamed existence) a solitary woman penned in. The truth is that it is Marie who is searching for Marie ... happy when no one watches her, when no one bothers with her, "wonderfully alone" and infused with a sense of self! . . " Further on he continues - "She is dangerous because she is living by the destiny she has chosen for herself which does not fit with what is expected. And her silence, which also makes her dangerous, she wears like the halo of her solitude ..." Too often the power of silence and of solitude have not been appreciated in my view. It is only here that one can find what one is about. The outside comes in, shouting, it forces you to acknowledge it, stamping around, like a crowd at a garden party flattens the grass and crushes the flowers. Left alone with its gardener, the space becomes perfect, grows harmoniously and beautifully. If the gardener passes by only now and again weeds will grow and what will become of the beautiful garden?

Solitude? Noise dies away and in the silence of the soul one can see so many things which spring back like trodden-down grass which stands up again little by little with a light rustle. One finds one's sense of self alright but it is dangerous too - for others. They are restless, speak, empty themselves out while, in front of them, silence rises; a torrent which, when it breaks the dam walls, will sweep away these empty vessels. Flaubert's image of a gutter overflowing suddenly is very accurate. One can polish oneself by using others but one must watch not to wear oneself away. One must not polish oneself so much that that the image of the other becomes engraved in us. I am getting carried away this evening but it is something I hold very dear and I will fight for that and my freedom all my life.

I met up with Cécile Péchegut. All she thinks about is eating. She leapt on my coffee ration coupon like there was no tomorrow. ${ }^{466}$ Did my 8 hours (counting in 4 hours of lessons). I only did Irish which I enjoy, interpreting old grimoires. Studying Etudes Litt. Classiques bores me to tears in comparison. To think I have to numb my brain over that when there is my thesis, Celtic - which I adore as Mme. $\mathrm{P}$ would say. I had a detailed commentary to do. My thoughts are flying so ahead of my pen that I struggle to keep hold of them [1p, 2 p?? So

${ }^{465}$ Madeleine Bourdouxhe (1906-1996) was a Belgian writer. She was a feminist and friend of Simone de Beauvoir who referenced Bourdouxhe's 1937 novel La Femme de Gilles in The Second Sex.

${ }^{466}$ Possibly to barter it for food. 
many spelling and grammar mistakes in French]. ${ }^{467}$ It is on Táin bó Fróech. I love the ring episode. The learned scholar recounts the tale dryly but the scenes leap like flames in the mind's eye. If only I could paint. "I swear on my life that I haven't seen anything as beautiful," says Findabair, "as the whiteness of Fróech in the black water with the red berries". Oh, the pointed chin and the grey eyes, the black hair which streams out and which tangles with the berries. Glistening arms, heavily laden, white, in the swirl of the greeny-black water. Findabair, completely white, with a large green hooded cape like a newly peeled flower stalk. In front there is Ailill, drunk among his warriors and his treasure gleaming under the light of the torches. Behind, but not clearly, is the milky whiteness of the 50 girls and the blue black sky. What poor taste, my dear - but I do love the colours, all the shades of red, garnet, scarlet, cock-of-the-rock, flame, tangerine, all the blues. I tried to look at the view out of my window pretending to be deaf. It was terrible. Everything seems flat. Good God, hope that I don't go deaf or blind.

\section{Saturday 14 August}

Did some Irish. Had lunch with Giselle and Denise. Denise came to mine. She is lovely. She thinks I am marvellous which gives me a curious sense of power. Poured down.

\section{Sunday 15 August}

Mass. Knitted. Will I have enough wool? Broke a needle. Listened to the news on P.S. "An Average Father speaks of his Average Son". He is frightened about what will happen after the war when his son comes back. How will they get along? Who wouldn't be worried about that? I am terrified about what the post-war will hold for me. With all my heart I want the war to be over but then what? Where will I live? What will I do? What will become of me? Where will I be able to live? Perhaps I will be able to find some work at home? Perhaps these questions will find answers more easily than I think. Anyway, I think that I have shown by not dying during this stagnant Occupation that with determination one can always find a way through. Sure enough, these are big questions which may not be resolved by a marriage and they worry me from time to time. But the really big problem, and one that really sends chills down my spine, is how I relate to my parents. There it is. I have said it now. I bet my life that in their hearts they hope that nothing has changed and that life will just take up where it left off in the cosy little threesome - foursome with the dog. But, well, everything has changed. I adore my parents, even more than before

467 'rattraper' is the verb Madeleine struggled to spell, crossing out two ' $\mathrm{t}$ ' and adding a second ' $\mathrm{p}$ '. 
perhaps, in that the separation from them has enabled me to be able to see just how good they are. I have been able to compare them to other parents - what a huge difference - I am so lucky to have parents who are just about perfect but, but, they love me too much. I am their sole reason for living - and . . . and ... Why didn't I have brothers and sisters - Oh, I know that they did want some. Nature didn't want it - but what a burden it is to be an only child. When I come back they will think that everything will be as it was before - but no it won't be. I have changed. I have lived for four years on my own. I am no longer a child. I even think that I have gone straight from childhood to adulthood and I miss the adolescence that I never had. I have made some amazing discoveries - that everyone [...] at the same age even if the body changes - that faced with authority, whatever that authority is, everyone grovels and follows and lots more besides - I have been too close to misery and to death to be how I was before and I do not share the same opinions as my parents. And what about my freedom?? Of course, they wouldn't complain. They would say 'Darling, just do as you see fit. It is your life not ours, ours is finished'. But their eyes, their eyes full of sadness - I'd never be able to cope with that. It is their life or mine. Why should I have this dilemma? A girl stays at home - well, yes, perhaps but not when she has had to earn her crust all alone for three years dictated to by necessity and with only herself to keep her going. I hope that I will return with a better understanding of my parents' love for me and forgive the wrongs they have done. Daddy - I misjudged him for a long time. I couldn't see his good heart under the rough exterior. What a dreadful life he has had. 14 hours a day stuck underground sweating over ovens or frozen amid refrigerators so that his daughter, who only loved her mother really and showed it so obviously, could have her heart's desire. I hope that it is not too late. It is four years since I left, 4 years and they are no longer young - and the bombing - let's hope that I don't go back to a deserted home. Oh, God. I hope they live for many years yet. When I think about all this I think that everything will just be the same as before but, then, I know what I am like. Since the age of 16 family life weighed me down. The only thing keeping me at home was the look in my mother's eyes. If I stay, I will be dead as a woman and will work; the housework, the gardening, I'll embroider beautiful tapestries and I'll take the dog out with mum and dad. I will have to get married. I'll live just nearby, say about $1 / 2$ an hour from home (on foot of course) But, who will I find to marry? Who would want me? I am not beautiful but I'm not ugly either - but I am fat - and then, of course, the education I have had - ! Oh Good Lord!! Maybe I will find a job which will mean I can live away - in my own house - but my parents will move, Oh God!! What can I do about it. I won't be able to live the way I want with them. It won't work. Dad will go on about the electricity that I use late into the evening. Mum will get irritated if I stay up late and neither will be able to sleep before I come up to bed. Oh what's the point worrying. I will go back. I will fall in love with a chemist or an engineer at university and him with me. We will get married and we will have ourselves a lovely house just next to the main road he'll go by 
car to work every morning and in the afternoon my parents will come straight over with Sammy - oh, no, Sammy will be dead by then. Oh God, why is it that the things we love have to die. Oh I don't want to cry again this evening. One sobbing fit is enough for this evening. Oh Hell, what a life this is. What did my grandparents do for my parents to have had such a wretched life. Mum loses her mother at 14 and has to live with a stepmother and a father who doesn't care about her. The 14-18 war ruins my parents' youth. Then poverty in a country they don't know. ${ }^{468}$ Dad works 14 hours a day, 13 days out of $14 .{ }^{469}$ Mum lives in a house that she hates. Then it's the Great Strike and the threat of the sack. Then it is the house in Nancy and the frightening totting up of the cost. I had nearly forgotten. Mum thrown out by her second stepmother and then mum gets TB!! They move house and everything seems to be going well except for the perpetual threat to Dad's job. He's old and can't see it. Then there's the war. I leave. Then it's the exode ${ }^{470}$ and four months of agony not knowing whether the only thing that they care about is alive or dead - no news and the separation goes on and on. The daughter who is so far away. The frightening telegrams. When will it all end? When will it all end? When I think about all that I feel that I will always stay with them. But, could I cope with so much love? I mustn't think about it. I mustn't ever think about it or else I would spend my life crying. - I need to go to bed. The radio has been on a lot today and it is half past 11. And what about my electricity ration? Phew! I have already eaten up the whole of next week's ration. It's the same with money - I've only got 50 francs left. I've done too much inviting over of friends - and the extra money from the cigarettes, Dilys doesn't want any and I promised 200 francs to Godfather - they have got so little money that I daren't give backword on that. I gave a packet to Cyla and I'll manage by selling the other even at a loss to be able to make up something of the 200 francs. And Mme P hasn't paid me for the month of July - 500 francs less makes a difference. Oh, I really shouldn't get so worked up - if I can get it everything will be fine again and life will be leisurelyand that goes for my parents' life too. I've never yet had reason to complain about [...]. Touch wood. ${ }^{471}$

\section{Monday 16 August}

Yesterday night I nearly got up again to say that I would support the entire family. I will stay proud. 10.20-11.50 alert. Le Bourget is in flames. 2.15-2.45 alert.

468 The Blaess family moved to York, England, sometime after the end of the Great War.

${ }^{469}$ Madeleine's father worked as a chef in a hotel in York, England.

${ }^{470}$ The flight of French civilians from Paris and the north of the country ahead of the German army advance in June 1940.

471 'Touch wood' written in English in the manuscript. 
Splendidly sunny. Darned. My, how my back hurts. I didn't see the moon come up and I was worried when a frightening orange claw gradually appeared. Then a huge orange moon appeared which, as it rose, paled - and it really did rise quickly. I was too hot last night.

\section{Tuesday 17 August}

Market. There was nothing to be had other than a few sticks of celery and a few radishes (and what queues!!) and grapes, grapes everywhere, (between 7.25 and 7.50 a pound). Washed the double sheet (it killed me - over a basin measuring $75 \mathrm{~cm}$ by $75 \mathrm{~cm}$ and without a boil-pot ${ }^{472}$ or a washboard, I could hardly manage it. Wrote to Aunts. Went to fortune teller at Dilys's and learnt that because I was born in the month of August I am very proud and good under a surly exterior; that I can get on well with everyone but being a high achiever I like honours and recognition and all that; that I'll struggle to get married and then only late on and then there will be an immediate divorce; that I am extremely independent; that I will be very comfortably off later on in life; that I would be better placed to succeed and that my worth will be recognised abroad rather than at home; that I get on very well with Mum or those born under my star sign or under Taurus who are all very intelligent (!); but never with my Aunt (why?) nor with my cousin (dilettante). The things one finds out!! I am being watched over by my grandfather because I dreamed about him and he spoke to me in the dream (He said to me: "You did know that your Uncle Julien died?" I said "No". He said "What do you mean? But he didn't tell you??). Did some ironing. I think that there is going to be a storm (what is wrong with my nib, since yesterday it's been all funny). The wind is getting up. 5.20-5.30 alert. They are Zazous!! Sicily has fallen. Saw a shooting star and had time to make a wish!! Hot. Flappée. Fed up.

\section{Wednesday 18th August}

I'm 25 years old - Good Lord, A quarter of a century already, nearly half of my life, at best a third. And what have I done with it? Let's not get into philosophy or we'll never get out. Darned - decided to study, but thought better of it and decided that I'd prefer things clean and I did some darning. I only have to keep the student bit up for half an hour each evening and that'll do the trick. Increasingly I don't want to take the exam in October. I don't know anything, I don't

${ }^{472}$ The 'lessiveuse' was a French invention; a metal container seemingly not dissimilar to the coffee pot principle of water shooting up and round the container when boiled and, in the case of the 'lessiveuse' cleaning and sterilising the fabric. 
study. It is also much too hot to make the effort. Supplies are so marvellous that I was forced to open a tin of beans for lunch being so tired of eating pasta and one can't just eat grapes. Great!! And what about this winter if I'm already starting on my stocks.

It was so heavy and humid at my place that it was airless at home. Went to join the Bibliothèque Municipale. The Librarian, just like the other woman who had given me information, couldn't believe that I don't live at home with my parents. Do I look so young then? Deep down, I am pleased about that. "Grandeur et décadence de césar Birotteau" (Balzac) ${ }^{473}$ "Le 18e sc" (Faguet). ${ }^{474}$ Then I went to the Luxembourg. Was dripping with sweat just sitting down. Wrote to Mad. Fortan - Maggy Desportes. Knitted. It is colder this evening. It is nice to be at the window in the breeze - but less good to be sat - after nearly 4 hours sat on an iron chair in the park. They should hire out little cushions.

\section{Thursday 19th August}

Went to the market. Nothing. Darned. Dreamed of "Rennard Heights! 7 rooms, large garden, chickens, secretary and job at Univ. Today (Friday) it has grown by a few rooms, a chemist husband and a car. My dear child. ${ }^{475}$ But this solitude is doing me a lot of good. Birthday card from Aunt. Lesson with Barland. What a sticky heat.

\section{Friday 20th August}

Darned. Heat even stickier. Card from Mad. Fortan who is back on Monday. Lesson from Komatsu, Barland. François comes for lunch tomorrow and I can only offer him pasta!!! Terrible. No potatoes opposite. What on earth can I give him? Terribly hot.

\section{Saturday 21 August}

Got some potatoes without having to pay because they had to get them from a cupboard where there were mice. Lunch of pork rillettes. ${ }^{476} \mathrm{Had}$ a veal escalope

${ }^{473}$ Honoré de Balzac (1799-1850). The novel was published in 1837, one of the Comédie humaine series.

${ }^{474}$ Emile Faguet (1847-1916). French Literary critic. Madeleine may be referring to his study of eighteenth-century French literature published in 1901. See the Edinburgh Review for more on Faguet and his works: https://archive.org/stream/edinburghreview196londuoft\#page/506/mode/2up 475 'My dear child' written in English in the manuscript.

${ }^{476}$ A kind of paté. 
and fried potatoes, brie, cake (brought by Françoise), grapes, pears, coffee. Not so bad. Great success, Lesson with Dudu. They've gone on holiday. Will they telephone me again? Went to Dilys to sell cigarettes. Gaël is adorable, a beautiful little thing but they are going to have a hard time with her - 'oh damn it all', Gaël was saying!!!

\section{Sunday 22 August}

Daddy's birthday - 55 years old? Poor, dear, Daddy. Went to mass at the Val-de-Grâce. The scene of a military burial in wartime could not be more moving. Radio Paris is not working - (alert?) Went to Villeparisis. Aunt and Yo were very happy to see me. They are going on holiday to the Cotentin ${ }^{477}$ peninsula - for good food. That will do them a lot of good. Yolande's organs haven't been affected but she is very anaemic. She's not hardy says Aunt. She's terrified about TB, it's awful. Sat at the end of the table with the family all squeezed tightly together - they forget sometimes to serve me. Only Godfather remembers - but I couldn't care less. I realised a long time ago that I am not a part of this family. In the evening Aunt gave me 100 francs for my birthday. They think that I didn't see Yo look over quickly and say "What are you giving her now?". Yo runs the house. She listens carefully to what I say so that she can reuse it later - more than once I have heard my own words reused cf that evening in the train about camping. Aunt said to me "Yo doesn't like camping, she doesn't like earwigs". My own words except I say [. . . ] $]^{478}$ and earwigs Yo scowled away because she knew I had said it. Strange expression from Aunt. At 8 o'clock she arrived "to consign me to the station . ..." Shouldn't it be relay? - Looked in the Larousse and what I thought was right. Went to see the plane, or, at least where the plane, a German fighter had come down behind Godfather's place, a 100 metres away. Hit in the electrics, it went all the way into the ground and was buried. I brought back two little pieces of it. Afterwards I pruned the climbing roses. Granny would like me to go and do the garden. Godfather doesn't like that sort of thing. Feel so wonderfully happy.

\section{Monday 23 August}

Cold. I still think I am in September. Still drying out that crushed salt - it is using an enormous amount of gas and takes ages. Waited in vain for Mad. F. Was starting to get into a bit of a state when she hadn't got here by 6 . I'd never have thought that I would feel as worried or feel anything in fact about her. Finally, at 7.55 a telegram was brought up telling me that she is coming back on Thursday; and a pneu (which should have arrived at $2 \mathrm{pm}-$ and which the

477 Spelt 'Cottentin' in the manuscript.

${ }^{478}$ Looks like 'veches' in the manuscript. 
concierge swears that she brought up) from Mlle Barland asking me to go to her friend's, 21 rue Fontaine, which is where she has gone with her stomach upset. It's strange, acting like this. She doesn't want to be on her own when she is ill and lands herself on friends. I'm the exact opposite; I don't even want visits. Very opulent at her friend's. lots of little fitted bookshelves - I've seen the same thing at Count Eudeville's but I hadn't seen shelves (above the bed) with the shelf just the size of the book. It's very good. I've taken note.

\section{Tuesday 24 August}

Darned - but finally finished the white knickers. Phew! Manicure at Dilys. I found out that I am psychic because I have two selves. But that goes back some way - I have gone back to being 'ordinary'. That gave me a start. I had always thought that I had lived my childhood over the other side. But still!!! Maybe I am scoffing too much potato. I'm as jumpy as a bowl of noodles. 'Nuff said!?."79 Around 6.55 am there was an air raid alert. Lots of excitement amongst the civilian population. We watched the planes come over. There were two squadrons one with 18 (or maybe 16 which I got when I recounted). The other was larger, around 25. Counting was difficult as the formation was very close together and there was lots of anti-aircraft fire which I'd taken for planes or parachutists or tracts first of all before it dispersed into smoke. 8.15 am and the end of the alert sounded when everyone had ceased taking notice.

\section{Wednesday 25 August}

St Louis. I must go to lay flowers on my grandfather's grave. It's a way away at St Denis. Goodness but it was cold this morning around 7 am. My cockscomb has been leaning over to one side as if she wants to fall over for a few days now. I think (damn this pen) that her end is nigh. But, she has lasted a while. Fifteen days ago I walked in front of the shop window and all the flower heads were dead and been stuffed under the display. And the [.. .] is still splendid (sorry, sorry pen you had just run out of ink). I think that I am going to trim it. It won't live as long but I want to replace it with a chrysanthemum or something. Wrote to Denise P to invite her to lunch on Saturday. I'm not keen but the poor kid is expecting to come. Wanted to write to Vendryès but put it off again. My French isn't good enough. Siel came back. I'll go see him. I'll get more out of him if I speak to him even though a reference is hardly asking much. Bought some beautiful bronze coloured chrysanthemums for grandfather at the market. Went to St Denis to take them. The grave is covered over with white stones surrounded by a curved silver railing. Someone had brought some bashed up flowers with China Aster and a geranium. I am pleased that I went - but goodness

479 'Nuff said' written in English in the manuscript. 
me, it is a long way. It's an entire afternoon gone!! Took the net bag ${ }^{480}$ to Giselle. Went to Aunt's to drop off the striped satchel. Had dinner there. Between 7.45 and $8.10 \mathrm{pm}$ there was an air raid alert but I didn't hear anything. Went with them all to the cinema to watch Tino Rossi in "Chant de l'Exile'". 481 He's a good singer, little Marie is beautiful. Pas Béni is funny but as for the rest - daft!!

Here we go! Here we go! I could have bet on it!! They are going to have a manicure. Ha, it worked. On Sunday I told them that I have them. I would have bet my life that they would. I wasn't wrong!! It's flattering to be copied and all that.

\section{Thursday 26 August}

Wrote to Vendryès and to Bachellery. It took me one and a half hours because I was so frightened that I would write badly. All for a simple reference!! Got eggs off Gilberte Frey - one missing, one cracked and possibly off and the rest just empty shells!!! I don't know what they do to wrap them up. Other people get theirs' intact. I'm sickened. 60 francs up the spout and no eggs.

My word, I regret being patriotic sometimes. Of course, I wouldn't look at a German even if it meant ending up dead in a dustbin. But, now and again - !! Went to get Panorama downstairs. The shopkeeper wasn't there but there was an adorable Hun. Tall, tanned, blue eyes, very pleasant. And goodness me, if he didn't address me "My Lady" ${ }^{482}$ and all so very nicely. I was sorry. He would have liked to know my name, to strike up conversation - but, well, he's the enemy isn't he? It is a shame that we are not at peace. Half an hour later and I am still thinking about him- that's bad. (ps: I'm sorry that he is not French). Did washing. The rain is pouring down and so it is not drying. Lesson with Barland. Mad. F didn't come at $15 \mathrm{~h}$ and came at 8.30 am having spent 6 hours at Dreux!! Sabotage on the line.

\section{Friday 27 August}

It looks as if it wants to be fine. My washing is still damp - and the sheet? Well - ! Only 2 days of holiday left. Woe, woe! I so hate the office! Lesson with Komatsu. I am always exhausted by this lesson. She doesn't understand the slightest figurative language and I have to explain as if I am explaining to a little child but it is worse because a child retains and applies it. Queues for food

${ }^{480}$ Unclear whether 'filet' is fillet here or net bag, its other meaning. Given the reference to dropping off a satchel in the following line, it may mean bag. Perhaps Madeleine borrowed them for shopping.

${ }^{481}$ Le Chant de l'exilé, directed by André Hugon, was released in April 1943. For more details see: http://en.unifrance.org/movie/37505/le-chant-de-l-exile\#techniques

482 'My Lady' written in English in the manuscript. 
cards. Ironed. Daily alert between 9.40 and 10.05 am. It is so cold. Darned. Lesson with Barland.

\section{Saturday 28th August}

Housework. Denise came for lunch (tomato salad, beef steak, fried potatoes (in lard given to me by Mad. F.). Salad, rice cake, grapes, apples. Pretty good! Mad. F. came to help bake the cake. Very anxious to do it well. It was perfect. Went to see "Goupi Mains-Rouges". ${ }^{483}$ Perfect, brilliant film. I was thrilled. It shows farming life so well! A brilliant film. It's a real documentary with some of the detail on rural life. Fernand Ledoux made a very good Goupi Mains-Rouges. I was struck by Goupi Tonkin's (acted by Robert Le Vignan) end - a remarkable acting-out of utter insanity. When he climbs up the tree, it is stunning. I would never have let myself be done over like Goupi; a strange little scaredy cat. The photography - brilliant!! Some magnificent shots. Jean was there in a light coloured hat. Jean looked like an awkward lump not knowing what to do with himself. Came back home and ate what was left of the feast. I have very bad stomach pain. I am not used to eating so much. I had to do the washing up too. I don't know what it is, whether I am getting old or what but it's amazing how tidy-minded I am becoming. I put everything back straight away and I don't leave the washing up hanging around, the housework is always done. This is not a recent thing. It's been going on for a few months and the longer it goes on the worse (or rather better) it is. Where do all these housekeeping qualities come from? If only I could cure myself of the impulse to put off everything to the next day.

Letter from Maggy Desportes. She is very sweet (my nib is awful and I can't change it. There aren't any). Today Aunt and Yo should be setting off on holiday. Curiously enough, ${ }^{484}$ I don't feel even slightly envious.

\section{Sunday 29 August}

Woken up at $6.30 \mathrm{am}$ by the buzzing of wasps round the grapes on the table. Mass. Adjusted white trousers. Baked. Made grape jelly but nervously and with some reservations because I was doing it a bit according to how I thought it should be and from very vague guidance. First of all, I over-filled my stewing pot. Then, wanting to press the skins I finished up tipping half of it on the blue dress and gave myself a boiling foot bath. I think I might have tried to press the skins too early. For $4 \mathrm{kgs}$ (a bit over) of grapes I got barely a pot. It reduces down

${ }^{483}$ Goupi mains rouges directed by Jacques Becker (1906-1960) was released in 1943. For further details about the film see the British Film Institute website: http://www.bfi.org.uk/films-tv-people/4ce2b6ab67b86

484 'curiously enough' written in English in the manuscript. 
a lot and I did spill a lot of it. Washed hair. Tired out. While I sampled (bread and jam) drying my hair in front of the open window I watched the wasps around the jam. When they eat, their back ends vibrate without stopping. They look as if they go about in twos. First two came, then a third which they chased away but which quickly came back with another. In the end there were 6. One fell on his back in the jam. When he got out I watched him clean himself up. He did his face first and then his body before having a taste. I took the jam away and they couldn't believe it stubbornly flying around the place where it had been as if it was going to come back. I'll be glad when the jelly is in a pot. I am tired out. I am worried about one thing. For some time now the merest mouthful of food gives me stomach-ache. It is quite worrying. Gosh, I am writing so badly - but it is not entirely my fault. My nib is all over the place.

$6 \mathrm{pm}$. Done it. The jam jar is now filled. It's really good - even over-sugared. I wish I hadn't put in the 5 sugar cubes now. It takes a good 6 hours to do it all from stemming the grapes to potting it all. What an awful lot of work for one pot of jam (which weighs, I reckon, 500 grams) which cost about 50 francs including the gas. But it is not as dear as the black market and I know what there is in it. All I have to do is wait for it to cool down - if the wasps let me at it. I wish Cyla could send me a block thing for juicing grapes I could make good cheap jam. I'd make it a little more runny than this because it would solidify a lot when it cooled down. I feel strangely tired. My pen is annoying me but it will have to last until the end of the war because there aren't any more to be found. Couldn't resist going to look at the grape jelly. It is as hard as rubber. I should have made it more watery - I could have made one big pot and one small pot. It would keep better. I was worried about the pan but it is fine. Nothing stuck. I like cooking.

\section{Monday 30 August}

Started back to work this morning. It feels like the holidays never happened. Most people stayed in Paris but everyone has a splendid tan. Mine is fabulous. And I have put on weight - I daren't weigh myself. Started exercises again this morning. Gilberte Frey is getting engaged in October. She's marrying a man just like that having hardly seen him \& barely knowing him. I couldn't do it. She made me pay for all the broken eggs. I think she's pushing it. Just a little more bran in the packing and it wouldn't have happened. Mme Felice has a great tan. She was only at the hospital for 6 days - thank the Lord that I couldn't motivate myself to go. I would have looked intelligent. Kort spent his holidays cycling around Calvados and the Manche. He spent one and a half hours telling us all about it which shortened the morning nicely. For some reason he comes out with: 'Don't get married, stay free as long as you can. That's the only piece of advice I can give you mademoiselle". That's great coming from a young man who has been married for barely six months!! Denise was even more chatty 
than usual. When she was at mine on Saturday she barely said a word. I studied for an hour this afternoon but made the mistake of going for a lie down for a rest for 5 minutes, because I was so exhausted I slept for 2 hours - and all the while my washing was boiling away. It didn't do any harm but my gas - ! Did washing and now at $6.30 \mathrm{pm}$ I am going to do some studying. The nap has put me behind with everything. It is odd how I fall asleep so easily in the afternoon. Beautiful day, very windy. I hope that everything will be dry by tomorrow so that I can iron it before leaving for the office - if Madeleine gives me back my iron. I washed my slippers which had had the grape jelly over them. No staining on the dress, thank God. I was scared about that because it went down the front but the petticoat is all red. I think that it'll go in a few washes. Mad. F. came to chat which meant that I lost an hour. Read Faguet's critique of Lamartine and Chateaubriand and it makes me want to read them. It is strange how I am now captivated by the classics. When I was younger I turned my nose up at them.

My misfortune continues. Wanted to stretch out my sheet to dry in the toilet but, I did something I never do, I didn't take off the other washing. Catastrophe; worse than a region laid waste. The wardrobe collapsed. I was worried about the glass bowls on top but they didn't break. I pulled free my jacket and a skirt. The rest will have to stay there until Wednesday which will be the first chance I'll have to clear it away. Went to bed and was all cosy when - horrible thought the feather in my hat!! I leapt up but all was OK. The hat was perched happily, feather in the air, on top of a pile of coats.

\section{Tuesday 31 August}

Got up at $6.30 \mathrm{am}$. Did ironing. Did the housework. Office all day. I am so fed up. Went to the carpenter's about putting the wardrobe back together. Bought $5 \mathrm{~kg}$ of grapes to make a jelly. It costs a lot but I will be glad of it this winter. Was paid. Air raid alert between 6.25 and 7.35. Annoying day. 11 pm got back from lesson with Barland. Shattered.

\section{Wednesday 1 September}

Around 3 am the anti-aircraft guns were banging away like mad. Office. Cleared up the bathroom. Made grape jelly. Studied badly because constantly distracted by the jelly and melancholic thoughts. Got letter from Aunt. Yo "is a child of nature"!! Letter from Bachellery inviting me for the weekend but I am doing something else on Saturday. Anyway, I don't want to. Go there a week on Sunday. Denise was unbearable at the office this morning. She talked without stopping with her arms folded. I felt as if I had my head under a waterfall, numbed by the water falling on my head and unable to catch my breath. I didn't put the radio on when I got home so as to have a bit of quiet. Mad. F. came to chat for an hour. 


\section{Thursday 2 September}

Was at the office all day. Went to St Lazare to get the train times for going to the Bachellerys. Wrote to Bachellery. Chose a present for Denise's 21st - quite pretty white dangly earrings. Got the flapjack for Yo which I will pay for next month. Went to Dilys in the evening. Did some radiesthesia ${ }^{485}$ So, I'll be marrying Teddy Baker in 1947 and I'll have 5 children by him!!! My dog will die. The English will land in France in October, the Germans will be out of France by February 1944 and I will be back with my parents in April. As soon as I got back I couldn't wait, obviously, to do the same with my ring even though the stone impedes the message coming through. I am going to buy a thing for radiesthesia and I shall see for myself. I am a good doctor apparently. Hardly!

\section{Friday 3 September}

9 am lesson with Barland. 9.30-11.20 alert. Stayed at Barland's until 11 am and then went to Dupleix on foot. As I was going over the Pont de Grenelle, lots of black and white smoke to the right and to the left. Renaud ${ }^{486}$ and ? A crippled plane dropped its bombs all over. The destruction is terrible. Lesson with Komatsu didn't happen. No water at midday. Office in the afternoon. Went to Mlle Komatsu's but didn't have a lesson. Drank coffee and chatted. Tired out. Melancholic.

\section{Saturday 4 September}

Office. Air raid alert 10.15-10.45 am. Had a good lunch to make up for yesterday. Manicure. Had tea at Françoise Boësse's. I do so like her apartment!! I'd be glad to have it were she to give it up. Looked after Mrs Evans and Gaël so that Dilys could go to the cinema with Georges. Knitted and talked. Mrs Evans said a very sad thing. "It's like Gaël is my daughter and not Dilys's. Dilys is like a stranger to me". She doesn't like Georges one bit. I think that she feels that he has stolen her daughter from her.

\section{Sunday 5 September}

Went to mass. Coming out I saw a man, quite an old man, who had fainted or else had died in the church. That would be a good death, just like that, suddenly at the end of mass. I certainly wouldn't want to be surrounded, be injected,

${ }^{485}$ Foretelling the future using pendulum dowsing, sometimes over Tarot cards.

${ }^{486}$ Madeleine probably means the Renault factories here. 
everyone wailing and saying 'She hasn't got long now' 'Shush, not so loud!' 'Oh, she can't hear anything now!' All that was dreadful for grandfather, all like ravens around the bed. I'd like to die suddenly or if I feel that the end is coming, I'd like to go alone in a little corner of the countryside. I wouldn't want there to be witnesses to my dying. I wouldn't want anyone to watch over me.

It's cold. There's a warm sun but the air is brrr! Wrote to Aunt Violette. I don't know what to say to her. We are so distant from one another. Once again she said: "I really regret now not having brought you but I didn't want the responsibility”. Heavens!! Does she think I am still 3 years old. I didn't know that she was still responsible for me. I think it is for me to decide what I want to do. Knitted. Nearly finished the front but because it wasn't right I undid it all. What a job!! Listened to "Le Renaud Bleu" on the radio. Well performed but all the characters are zazous. Lord they are complex - and what for? I'm sleepy but I am not tired. I'm not sure how to explain that. The mere thought of having to go back to work tomorrow - uh! I'd like to be ill, something, let there be an air raid alert, it annoys me so much!!

\section{Monday 6 September}

Between 2 am and 4 am there was a pounding of guns - a huge din. Left for the office; in the métro at St Michel, air raid alert!! (8.35 am). Got out sharpish and came back here by the side streets because the police were out in force. Getting across the Rue Soufflot was a bit scary but I managed it. Got back at 9 am and just as I did so, the alert ended. But, I'm not bothered. I have a nice half hour here. The métro is supposed to get going again in $3 / 4$ hour but I am in no hurry! Arrived at the office at $10.20 \mathrm{am}$. I'm doomed as far as St Michel station goes. No sooner had the métro arrived then there was another alert. $12.30 \mathrm{am}$. Got my skates on to get back. A mad race. Five cops on the rue Gay-Lussac, St Jacques were stopping everyone - and I got through!! Thinking about it afterwards I reckon that it was because they recognised me because I live in the quartier. 12 am. End of the alert. Paid the electricity. Worked like a saint on my Irish. Bought some [. . . ] for my circulation which is atrocious. Drank two bowls, one at $4 \mathrm{pm}$ and the other now $(11 \mathrm{pm})$. God I am so hot. I think that I'll be drinking a lot of it this winter. Cooked once again the 6th batch of grape jelly that won't 'jel'. My two pieces of sugar were what was needed I think. Didn't have the time to knit because Mad. F came to talk. I gave her the ladle to lick. She loved it.

\section{Tuesday 7 September}

+ Office all day. Filled out questionnaire for the office and when I got home I found another one!! I don't like all that. Letter from Bachellery. Lesson with Barland. I. Ill “Anderby Wold” (W. Holtby). 


\section{Wednesday 8 September}

+ Office. Ill. Couldn't work this afternoon, a ton on legs. Dilys is drugging herself up on coffee!! Italy has surrendered!! "Voyage égoïste" (Colette). She is such a good writer. "Les Celtes et la Civilisation celtique" ${ }^{\text {"87 }}$ (Hubert). Gosh I feel sick and my legs are so heavy. Worn out. I

\section{Thursday 9 September}

+ Office all day 9.15-10.45 air-raid alert. Saw 75 planes. It seems that a plane and a parachutist came down. Went to the Red Cross: "Still haven't had your news. Holidays over. In excellent health. Family and friends send kind thoughts. Happy birthday to Daddy. How is Barbier, Nibs, Sammy and everyone? Much love, kisses and hugs." Was supposed to be going to Dilys's to look after her mother but she didn't go out. Didn't work because I read "The Crowded Street" ${ }^{\$ 88}$ (W. Holtby). It is terrible how this reading demon can get a hold of me. I drop everything to do it. Didn't feel too bright. Raining. I.

\section{Friday 10 September}

+ Wrote to Bachellery. Picked up one book on Celts (Hubert). Phoned Sabine Vialla. I [. . . ] by her voice. Went to Komatsu's who has to go some to finish her translation of "La Moisson de "40" (Benoiste Méchin) ${ }^{489}$ before the end of the month when the Nippon envoy returns to Japan. Lessons have been put off until next month (not good for my finances!). Office. Went to Sabine Vialla's. She is charming, delightful, adorable. We talked about everything, about the office, intellectual things, about getting food, about "Samson" which she is writing, about archaeology, about Celtic studies - and no fee! Met her mother. Sabine gave me half a bar of chocolate (stayed 2 hours!!) Lesson with Barland. If it is true, the arrest of Mussolini on the 25th July was ridiculous. Tied to a stretcher and carried into an ambulance. What a knock to his pride. So shaming. How can the Germans publish all the facts? I'd die of shame. I'd rather commit suicide.

${ }^{487}$ Henri Hubert (1872-1927). The text Madeleine refers to is most likely to be Les Celtes et l'expansion celtique jusqu'à l'époque de La Tène, published in 1932:

http://gallica.bnf.fr/ark:/12148/bpt6k921326

${ }^{488}$ First published in 1924.

${ }^{489}$ Jacques Benoiste Méchin (1901-81 ). A diary of life as a POW after France’s defeat in 1940. 


\section{Saturday 11 September}

+ Pretty sunrise. I love my apartment. Office. No meat this week! Glad that I didn't get my tickets last Sunday - had the mutton. News from Mummy: "patience, news will get through, Andrée is working with Nibs, Colette, medicine. Germaine got messages from Lecler. Gilberte died after an operation. Everyone is fine. Us, Toutou \& friends all send much love. Mummy - 9 July". Was very shocked about the news of Gilberte's death - how old was she - 28? Poor, poor Germaine. Raoul leaves her and now the terrible death of her child. Poor woman. Did I say that when I was at the Red Cross, I had seen two machine gun posts on the Av. de la Grande Armée? The buses used by German troops as well as the hotels and the bars are protected with mesh. They say that the trains going North aren't running - that'd explain why I haven't heard from Aunt. She must be going mad if she is stuck over there in that tiny place. Manicure.

Confession. Brought back the extension cables. I'm going to be fine for working in the evening now without using too much electricity. 6.45 air raid warning, 7.25 end of the warning without anything happening. Went to look after Mrs Evans. Miss Beach came over. Very pleased to see her. Françoise Bernheim has been deported. It is terrible. HB . . e escaped by sheer chance. Listened to "Russian Commentary" where everything was "cheerful" 490 - Russians who had nearly died, trains, villas they had strewn with flowers standing amongst the ruins - [. . ] the Alamani ${ }^{491}$ My room is looking very sweet with the indirect lighting ${ }^{492}$ and I will use less. I need some biscuits and some mineral water in case of accidents. I. It's a year since Godmother Berthe died.

\section{Sunday 12 Sept}

Mass. C. Heard a huge row on the landing, it was the young woman from Martinique and her husband; they had killed a rat as big as a 4 month old cat. My legs were trembling. Wrote to Maggy Desportes, to Godfather and to Granny. I'll need a lot of money to dress smartly - alas. I'll have to do some work on my cherry-red dress for going to Sabine's on Saturday and I'll have to go to the hairdressers beforehand!! Sylvia said that I dress "so meekly". ${ }^{493}$ I will not be meek. Oh God, I don't want to be forever the doormat. I need more self-confidence hard to put back what 13 years of school tried to take from me. I didn't know that Sabine Vialla was - at least her pseudonym is - Maria Le Hardouin, the one

\footnotetext{
490 'cheerful' and 'Russian Commentary' in English in the manuscript.

${ }^{491}$ Possible reference to the Alemmani (Alamanni) tribes?

492 'Lighting provided by reflection usually from wall or ceiling surfaces'. This is taken from Schorsch.com.

493 "so meekly" and 'meek' written in English in the manuscript.
} 
who wrote "La Voile Noire". ${ }^{494}$ Detourne or Letourne ${ }^{495}$ was the name she was born with, she used to live in Troyes. I adjusted my red dress, pulled it in under the sleeves, covered over the buckle and shortened the dress. I am shattered. There is a dramatic chivalric moon behind the tragic black clouds.

\section{Monday 13 September}

Slept in (7.10 am). Mussolini kidnapped (taken away) by parachutists!!! Never a dull moment. Office. Rain. Slept for an hour without meaning to. I want to get married. I think that I am going to get a boil on my behind. I should take a purgative. Marvellous sky this evening - a luminous lemon blue sea with grey mist in the distance. Two arms of a rainbow - the other arm very [. . . ] to the left of the Val-de-Grâce. Then orange and flame coloured. Above it grey clouds against a blue sky. Very strong wind. I go back to my Celts.

\section{Tuesday 14 September}

Office all day. Record - 10 hours work $-6^{1 / 2}$ at the office $2 \frac{1}{2}$ studying, 1 lesson. Mlle Barland was half asleep. Full moon. Bad ovulation pain. Odd experience in the lift. Was going down with the fair headed boy from the 7th floor who lives next door to the Zazous. I hate it when silence weighs as heavy as lead. He had a very big bunch of keys in his hand; looking for something to say. I said "Good God, I thought it was a revolver!" "No, I don't have it on me at the moment" (he's the police officer then). "Was it the clinking that made you think that?" "No, it was your hand being closed around something" "You are on edge Mademoiselle". Of course, I protested but without being able to say to him that it was just to say something having only thought of the revolver after having seen the bunch of keys and making the comparison. "No you are edgy - it was the 'Good God' that gave you away". Interesting that Good God = fear. Thought about it afterwards: Am I fearful? Instinctively I would say no but . . . ? I don't deliberately go against the rules, I don't like hurting be it physically or emotionally. I am sensitive to the opinions of others, an unexpected ring of a doorbell or telephone makes me freeze, meeting someone unexpectedly rattles me; and in a sweat my body just acts automatically. But no one notices. My mind is stronger. Bought fabric for Gilberte.

\section{Wednesday 15 September}

Still got pain in the lower abdomen; it's all hard and swollen. What a day!! $2 \mathrm{pm}$ went to the hairdresser, $4 \mathrm{pm}$ was starting the washing up when the doorbell

${ }^{494}$ Marie Le Hardouin (1912-1967). Awarded the Prix fémina in 1943 for the novel La Voile noire.

${ }^{495}$ In fact, she was born Sabine Outhoorn. 
went - Aunt Violette!!! I was flabbergasted!!! She had brought me back my suitcase and gave me a little bit of veal, a camembert and a few apples!! She stayed for 2 and a 1/4 hours. Charming and chatty and very lively!! Thought that my garden was sweet. Gosh, I could have fainted. OK now. I have the feeling that they are going to carry out raids now and again. Madeleine Fortan came over. We were talking when at 7.30-9.00 there was an air raid warning but for real this time!!! First of all 7 flying fortresses then 4 (they said 6) squadrons of 28 planes. I saw 2 planes shot down, one was in flames and was like a star. The other rolled over and over as it fell. It was like being at the cinema. I was more perturbed by the horrified faces all around me. Huge smoke clouds. The little woman from Martinique ran away screaming we all rushed to her place. We could see huge smoke clouds over the Porte de Versailles masking the Eiffel Tower rising in the air for kilometres. I wasn't frightened at all. The flak was pounding so much that everything was shaking and large star bursts could be seen within and above the squadrons but apart from 3 which were smoking a bit there was nothing else. I saw two parachutists from crashed planes but the sky was so blue that it hurt to look. When the first was brought down the concierge came up her eyes popping out of her head and screaming 'He's falling on our building. 'Poupette', the policeman's wife as white as a sheet was following her husband around holding runner beans in her apron. . saying nothing, understanding nothing, sticking to her husband like a shadow. Dilys said that when the plane started to fall everyone in the street watching the planes started to scream and run towards the Val-de-Grace covering their heads with hats, papers, helmets and frying pans. After the air raid I felt very, very cold and tired. No tap water. I had to drink some mineral water. Cards from Bach. ${ }^{496}$ and from Jacqueline Prévost (Piatier).

\section{Thursday 16 Sept}

It is 3 years today that I left Aunt's to go to 4 rue Rollin. ${ }^{497}$ No train is running out of St Lazare. Kort gave me a real dressing down for 'innumerable cataloguing mistakes' that I've been making and I will have to move departments if I don't stop being all over the place or, at the very least, that I no longer do any cataloguing if I'm going to make so many bad and repeated mistakes - there were THREE documents which had been wrongly catalogued out of all the hundreds which I have done this month. One on poppyseed oil put in oleaginous plants, one on weed identification put in insecticides, one on aeronautical engines put in plane engines. What a funny man. I was thinking that I had wrongly catalogued a good forty!! He made himself scarce before I could say

\footnotetext{
${ }^{496}$ Bachéllery.

${ }^{497}$ First mention of the date Madeleine moved out of her lodgings with her aunt to move into rue Rollin with Ruth Camp.
} 
"is that all?" but afterwards he was as nice as nice could be. What an idiot!! Was at the office all day. "Return to Yesterday" (Ford Madox Ford). It was pounding away around $1.30 \mathrm{am}$, women were running for the shelters, German officers were walking like crabs looking at the sky. Wished Denise a Happy Birthday. She is as pleased as Punch with her ear-rings. Gilberte gave her roses out of her garden, I will give her flowers Saturday morning. Went to look after Mrs Evans and Gaël. Letter from Barland. Dilys is jealous that I am Sabine Vialla's "secretary" or near enough. Had lunch in the Parc Monceau.

\section{Friday 17 Sept}

Wrote to the Service des Délégations and Bachellery. Ironed dress. I am sure that it is too short. Wrote diary. I've got a real cold - rain. Office. Lesson with Barland.

\section{Saturday 18 Sept}

Denise Pedron 21 years old. Gave her 2 roses as a present. Office. So nervous about tea that couldn't digest the cabbage. Had to lie down. Manicure. When I was getting ready to leave, Dick arrived to start up lessons again. He thought I looked nice. Tea with Sabine Vialla. Charming. Air raid warnings - 12-12.20 and 7.05-7.25. After tea, went by Dilys's with Madeleine to make her jealous. It worked completely. Letter from a Madeleine Rochette for lessons. Godmother Berthe was buried a year ago today.

\section{Sunday 19 September}

Mass. Went to Montalet. Very pretty. The Bachellerys live in an old abbey. A baby has brought out the human side of this intellectual couple who were really charming. Met a Mme Jacob, lovely woman, very worn down by what it happening to her and horribly thin. ${ }^{498}$ Picnic in the afternoon on the Issou heights near to Vexin. Went and came back on a double-decker bus. A lot of houses destroyed near to Asnières and Courbevoie. William was very kind. Escorted Mme Jacob back to rue Monge. Brought back tomatoes and apples. Cold has gone.

\section{Monday 20 September}

Office. Dead tired. Slept an hour in the afternoon. Lesson with Dick. Went to look after Mrs Evans. Gaël made a horrid scene about going to bed which really upset me. Spoke with Mme Baron, very nice. Letter from André.

498 This is very likely to be a reference to anti-Semitic persecution. 


\section{Tuesday 21 September}

Office all day. "She" (Rider Haggard). 499 "The Importance of being Earnest" and "Lady Windermere's Fan" (Oscar Wilde). 10.35-11.25 alert. Invited Denise to dinner. Lesson with Barland.

\section{Wednesday 22 Sept}

Office. Slept in the afternoon because I couldn't stay awake. I should have written job application but too exhausted. Have been going to bed at midnight since Wednesday without a minute's rest nor time to do the housework. Second letter from Rochette. Letter from Granny. Has Jacqueline Piatier come back? Wrote to Rochette, Bachellery, Aunt, André. Alert 5.15-5.35 pm. Lesson with Dick. Went to bed at midnight again!!

\section{Thursday 23 September}

Office all day. "Thirty Clocks strike the hour" (V.Sackville-West). She describes the characters admirably. "Experiment in Autobiography". Had lunch in the Parc Monceau as I did last Tuesday. It is splendid out in the sun. Went to bed early (7 pm) but read H G Wells (Exp. in Autobiog.) He says some very just things. I admire this man a lot. 7.10-7.25 alert. Bought "Panorama" for the last time I think. It is no longer worth $3 \mathrm{fr} .^{500}$ Intrigued by the short story that got first place ex aequo in the under 30 section of the competition: Procal Renoux ("Le Gire"). Ideas, images, vocabulary but unintelligible and incoherent. Am I out of touch or just stupid? Around about $11 \mathrm{pm}$ there was a violent burst of anti-aircraft fire, the worst yet. Got up to fill a basin with water. Was worried but not frightened.

\section{Friday 24 Sept}

Around 2 am it started up again with even more violence. Everything was lit up by the continual flashing of the anti-aircraft fire. Whistling of bombs and zooming of a shot down plane. So close!! Huge glare. Went to the rubbish chute to take a look but so much shrapnel was falling that I had to beat a hasty retreat. On the way back, I was pleased that there was a roof or otherwise there would be no more Madeleine. I am sure it was happening right where I was. I was frightened. Not very but the sort of fear that makes you say I'd prefer to be

${ }^{499}$ H. Rider-Haggard (1880-1925). For more on She see: https://www.britannica.com/topic/She-novel-by-Haggard.

${ }^{500}$ Panorama was a weekly magazine covering literature, fine art, cinema, theatre and current affairs. It appeared between 1943 and 1944. 
standing up, less to hit than there would be if I was lying down and to wonder whether I needed to put a pillow over my head. Fell asleep and dreamt that a German officer wanted to marry me despite my resistance and the fact that I was engaged to a Frenchman. Read Wells instead of doing the housework. I have two major vices - putting off what I could do today to tomorrow and READING. But this latter vice is terrible. Wells also went against marriage. Every man seems to do so unless they are absolutely conventional. When I think about it, I would have been Jean's mistress if I had loved him because he didn't want marriage, offering the prospect only so as not to upset me and all the time thinking that I didn't love him. If I had loved him I would have slept with him marriage or no marriage. But, whilst I don't object to marrying a man I don't love, - so long as I respect him and we get on well, I will not be someone's mistress on the same terms - particularly if respect does not exist. The marriage sacrament is like a business arrangement in order to build society where there are rules. Sex outside of marriage is only there for the pleasure of two people and it bears no fruit. The ideal would be to have love in marriage but it never lasts. It is much better to go into an arrangement with one's head screwed on than to go from disappointment to disappointment. Went to 15 rue Soufflot for job. Took laundry back to Jacqueline Prévost (née Piatier). 12.40-1.05 alert. Alerts always relax me, when there's nothing, because at least I don't have to think about going to the office. I should have left from here at 12.45. As it is I'll go without rushing around $1.30 \mathrm{pm}$. Broke a glass but it was already badly cracked.

Office. Alert 5-5.30. Waited for Dick who didn't turn up but met up with him afterwards. Met with Madeleine Rochette about lessons. She is very nice but too reserved. Flew back here to eat but Mad. Fortan had her talking head on so swallowed $100 \mathrm{gr}$ of bread and ran to the lesson with Barland. Was late but she was even later. Her father made me welcome. He works for Bon Marché! 11 pm. Too sick to eat. ${ }^{501}$

\section{Saturday 25 Sept}

Office. Rain. Letter from Aunt. No Villeparisis but walk with Aimée and Huguette in Paris "given the nice weather". It's looking as if it'll be a great Sunday. No meat this week - and what about my tickets? Manicure.

\section{Sunday 26 Sept}

Mass. Cold. Went to see Aunt - Yo has got tonsillitis. They could have warned me!! I managed to entertain the invalid. Aunt, Yo were so charming. Slept over. 7-7.25 am alert. Rained.

501 Alongside the entry of 24th September, Madeleine writes, 'the plane fell on the big shops on the rue du Louvre'. 


\section{Monday 27 Sept}

Arrived at the office $1 / 4$ hour early!! 11.20-12.15 alert. Bored because nothing to read. Cleaned from top to bottom and in the middle of doing it Mme Beaugrand came to book a lesson, she's so chic and I am so grubby!! Anyway, she's charming. I start tomorrow. Lesson with Dick 6.25-6.50 alert. Dick is getting "fresh". ${ }^{502}$ I don't think that his intentions are strictly honourable. Lesson with Madeleine Rochette. Lesson Mad. F. 10.20 the anti-aircraft guns started firing. Tired out. Because I have a bit more money I am going to adopt a prisoner. It is a little late in the day but I couldn't afford it before. I could write loads but I am going to hurry \& get down some [...] to warm me up and go to bed. It is so cold. Office and Kort is sulking with me. Right now I can't do anything right for him. Denise not there this morning - registering for exams.

\section{Tuesday 28 Sept}

Office all day. 5.15 lesson with Mme Beaugrand. Tiring because she is so stubborn. Raced back to have dinner. Sent pneu to Aunt about dinner tomorrow. Lesson with Barland.

\section{Wednesday 29 Sept}

Office. Went to collect godson. First went to the Prisoners' Parcels Office (closed) then to the Prisoners' Family Offices (Mme Atmans), got sent to the Prisoners' Chaplaincy. Lesson with Dick. Dinner with Aunt, Brought vegetables back from the Villeparisis plot - a big courgette, a little pumpkin, a little cabbage, 10 tomatoes.

\section{Thursday 30 Sept}

Office all day. Went to the Chaplaincy. Quite badly organised. Finally got a label for a Camille Cavé and a card to request a prisoner from Stalag 1A. Could I take 2 prisoners? Or just one? 1, I could manage, 2, I would have to go without (I am talking about money because I will send parcels through the Town Hall). I am going to sleep on it. Lesson with Mlle Rochette. Went to Chabert. Card from Maggy Desportes. Rain. Went to bed early thank God.

\section{Friday 1 October}

Got up late. Still undecided about the prisoners. Of course, I'll send a parcel to Camille Cavé even though I have to [...] the first packet. But will I have to write

502 'Fresh' is written in English. 
to get another one? And another thing. What other subject am I going to take? Went to the Sorbonne on Wednesday and found out that my BA does not count as a licence libre because I am French!! So many things I cannot have because I am French!! I will have to have another qualification alongside the Etudes littéraires classiques in case I fail it. I'd like to do Psychology . . . .

Why not have 2 prisoners? It would not be a big sacrifice for me and it would mean so much for "them". Wrote to the Chaplain of 1A, Pierre Dubois [25519FZ]. It was difficult. Now, all I have to do is wait.

Office. Mme Felix wasn't there. Roche, Bayard suspicious ${ }^{503}$ so sent [....] ___ ${ }^{504}$ and she wasn't there. Richter, Zaukel's right hand man was assassinated a few days ago and since then there have been 6 murders. We'll surely be punished Sunday and perhaps Saturday. That'll give me time to get on with things. Lesson with Barland. I am exhausted and feel anxious. I hate it. I look as if I am in fantastic health but there are only about 3 days a month without illness or some woe. Homesick. ${ }^{505}$ Depressed and tired most of all. And to say I have to get up early tomorrow morning to see Mme Felix before the office. What a stupid little idiot.

\section{Saturday 2 October}

Went to Mme Felix's. Not there. The things I have heard said about her!! She was at the office. Didn't telephone Dick so no lesson. Didn't have a manicure. Tired, ill, went to concert. Jean de Rohonzinski ${ }^{506}$ was in a very bad mood. But the concert was fabulous. Really enjoyed Bach for the first time.

\section{Sunday 3 Oct}

Mass but didn't go to Villeparisis because I was tired and fed up. It is the only day when I can get some rest and if I have to go chasing around again!! We were expecting there to be a curfew but there wasn't. 3-4.30 pm, alert. A plane fell Pont de Tolbiac. 7-7.30 alert. Darned and knitted - and had a good rest.

\section{Monday 4 October}

Clocks went back. Nice to stay an extra hour in bed but as strange as anything in the streets; and this evening I was shattered because it was $11 \mathrm{pm}$ (midnight really). Office. Denise talked, talked and talked. I could have killed her. What's more I'm in a very bad mood. 12.35-1.10 alert. Washed blouses etc. Scrubbed

\footnotetext{
503 'suspicious' written in English.

${ }^{504}$ Illegible word then a gap left in text.

505 'Homesick' written in English.

506 Jean de Rohozinski.
} 
around with the wire wool, did the housework. 4.45. Lesson with Chabert. 5.50 lesson with Dick. 7.15 lesson Rochette. No lesson with Madeleine. I was sure that she would pack in. Wrote to Aunt, Villeparisis, prisoners. So many things!! Saw the new quartier en plein air - good sign. I'm very thirsty which is a rarity. Sleepy byes because I'm very tired. Cold but things are drying quickly.

\section{Tuesday 5 October}

Office all day. Lesson with Beaugrand. She is so, so stubborn!! Lesson with Barland.

\section{Wednesday 6 October}

Office. "James Joyce" (Gorman). ${ }^{507}$ I didn't know that Joyce had taught English abroad. By mistake got "My American" which I had already read. Sickly and tired. No desire to go out. Blue sandals broken. Went to see Maggy Desportes. Very happy to see her and she me. Katy looks like a little boy, a little too thin. I think that I am going to do Celtic archaeology. Brilliant. Lesson Dédé. Went to bed. early. Maggy gave me 1 egg and a camembert.

\section{Thursday 7 October}

Office all day. Lots of upset. Mme Broussard and Mme Marguerite were threatened with the sack. What's more, it looks like the Centre will be closed in December. I will have to look for something else. "Walter de la Mare" (R.L. Mégroz). ${ }^{508}$ "The Years" (Virginia Woolf). ${ }^{509}$ Not bad, read it already. Went to the Red Cross. "Got message from July. Sympathy and sadness death Gilberte. News André, health good. Congratulations Andrée, Colette. Happy birthday Daddy. Send your news. Hugs and kisses, thinking of you". Lesson $1 / 2$ hour Chabert, lesson with Rochette. Read til 2 am. 1.30 anti-aircraft fire. I

${ }^{507}$ Herman Sherman Gorman (1893-1954). His biography of Joyce was reviewed by Horace Reynolds in The New York Times in February 1940: http://www.nytimes.com/books/00/01/09/specials/joyce-gorman.html

${ }^{508}$ Rodolpe Mégroz (1891-1968). English novelist and art critic. The University of Reading holds his personal archive comprising letters, photographs, notebooks and journal articles:

https://www.reading.ac.uk/special-collections/collections/sc-megroz.aspx

${ }^{509}$ Virginia Woolf (1882-1941). A contemporaneous review of The Years, 'Virginia Woolf's richest novel', was published in The New York Times in 1937: http://www.nytimes.com/books/97/06/08/reviews/woolf-years.html 


\section{Friday 8 October}

Bought shoes. Lesson half an hour with Chabert. Went to Komatsu's. Not there. Corrected application for teaching. Office. Lesson with Dick. No Barland. I.

\section{Saturday 9 October}

Office. Pneu to Aunt saying that I am not going tomorrow; pneu from her saying that Marcel is there. Pneu to her saying that I would come. Note from Dilys for me to go at $2 \mathrm{pm}$. Urgent - and she leaves in no haste at $2.45 \mathrm{pm}$. Manicurist arrives at 3.30. Afternoon ruined. Gaël is becoming objectionable - she was anything but pleasant with me as her mother looked on smiling tenderly. For a 2 and a $1 / 2$ year old she has a fantastic vocabulary. And she speaks so clearly!! You'd think she was 6 or 7 years of age. I think that Dilys spoils her too much and it's a shame. Her hair is wonderful, adorably fine. I must have one of those colds coming. The butcher had some meat - the only butcher in the whole of Paris. They say that it'll be three weeks before our ration tickets will be honoured. 1-2 (90gr). In September we had 217 gr of meat - but since Wednesday we have had 25 gr more bread a day. That makes 300 gr a day. But there isn't much getting through. For two days I ate just pumpkin. It's going down. Tuesday: Lunchtime $200 \mathrm{gr}$ of bread and butter, 3 pears, evening $100 \mathrm{gr}$ bread, plate of pumpkin. It isn't enough. I feel ill constantly too. Since having eaten I feel a bit better. It is very cold. You could imagine it snowing.

Denise disgusts me - together, she and her brother bring in 3,300 fr a month (between 3, they have $1000 \mathrm{fr}$ rent a quarter). The medicine for her mother costs $400 \mathrm{fr}$ (or thereabouts). They owe in the region of 4 to 5,000 $\mathrm{fr}$ and have only $300 \mathrm{fr}$ left to get through the month (it's the 9th). They are going to have to sell something and there's the little matter of the 100 to 200 frs commission on shopping which she blows on getting her hair done. Ok, the 50 frs she gets from her mother each month is not enough - but she can't do much more. She could at least have the good manners not to go out and get her hair straightened when her parents are having to sell the crockery. I do like Denise - but she has an unpleasant side and is not easy to be around, always flying off the handle. Her mother is the same of course but even then ... !! Some faults I just don't mind but disloyalty to one's family - no! At the same time, God knows, I do like the family - at a distance. The family unit, parents and children, should never be divided. Sisters and brothers are different, they are in different units.

Denise doesn't reflect on much. I spoke to her of the cost (moral) that one pays for everything - "Take what you want" said God, "take it - and pay for it". ${ }^{10}$ She got really irritated and decreed that I spend too much time thinking!!

510 “"Take what you want" said God, "take it - and pay for it". Sentence written entirely in English. 
At the office - the parents of M. Delbot (collaborators) and their daughter (17 years old, a collaborator too) received little coffins on which was written "Sentenced to death". I find all that pretty puerile. I

\section{Sunday 10 October}

Woke up, voice gone and bad stomach ache. Thick fog. The thought of having to go to Aunt's. What annoys me is that it is my only free day and next Sunday I will have to go to Villeparisis because I have been away for too long. But I will go even if my body doesn't want to because I have two selves. There is one that loves me and thinks only about me being happy and the other, it is the opposite. The first nearly always obeys when the second self shows up - in fact, I could say that it always obeys.

Sometimes I feel that I am not free and that I have to obey - if I don't, I feel I have done something wrong and worry about being punished - something bad will happen. These two selves are increasingly in evidence just lately. I suppose that one might call that having a Catholic conscience. That 'self' never loses her head and is as hard as nails. In a crisis when I am frightened or emotional or dreaming, it is this self who speaks, who acts outside of me. I only seem to realise what is happening to me or what has been said to me some time after it has happened. Have I a 'double'? I don't think so, I think it is the 'me' I have been trying to become since my youth. I've let this go since I have been in France, other than now and again - because I don't feel that I have a purpose, no, that can't be right - I feel that I am waiting before getting back my "drive" 511 to go for my goal.

Yesterday the manicurist told me that at 25 (ie: this year) I will be in danger of death if not dead. That doesn't scare me. I do not think that I am going to die but I do think that I am going to have a very serious illness. What is written is written. My poor parents if I die. But, as I said, I don't think that I will. I do sometimes think that I might have an illness back home in 18 months time. After applying for jobs at universities (I am not sure whether I will get one) I will get married to a lecturer probably a chemist. Then I will get a big house in the countryside with chickens, large gardens, an orchard etc. I can't decide between two plans. Neither are brilliant. The halls of each are too big, the stairs are difficult to fit in. I've done it approximately and it is not quite in proportion. I'd like an aquarium but set back in a wall like a window and lit up at night. Why not? And I'd like a bathroom for each bedroom. An office for my husband and an office for me and a lot of bedrooms because I'd like four children at least, please God. ${ }^{512}$ The Brown's house is alright but I prefer the main door at the front. There needs to be a wash basin on the ground floor with cupboards so that the children can hang up their coats and wash their hands before coming

511 'drive written' in English in the manuscript.

512 'please God' written in English in the manuscript. 
in. There will be central heating everywhere but fireplaces too. There'll be an oven and a fridge. A big window over the sink etc. Gosh so many dreams! Linen cupboards, sink, sewing machine, table, bed because that room will be a sick room as well. I'll need that if I have lots of children! Mass went to Aunt's. Put on an act and it worked. I was ill but not as much as I seemed to be. Anyway [. . .] is amazing painkiller. Went to see "Grande Marnière" with Fernand Ledoux, Jean Chevrin and Robert Le Vigan. They acted well in a run-of-the-mill film, although the last scene in the courtroom was pretty gripping - it's a classic device which rarely fails. Very misty. I.

\section{Monday 11 October}

Office. Robert Guillou came by to see Mme Roche-Bayard about Denise and now she works from home. The poor little woman bemoaned the fact that the measure didn't apply to me. It was touching. But although it would be good for me to work at home instead of coming in to the office Kort suggested that I work the whole day for - hed try to get it - 2,200. It is not worth it. I said that I need my Friday morning and that I would think about it. I have thought about it. I am going to try to see the Teaching Appointments Officer tomorrow. Got letter from Mme Beaugrand putting her lesson off until Thursday. Dilys came to get me because M. Dougall can't give a lesson this evening and Dilys is not allowed to go out. ${ }^{513}$ I agreed. I'll see. I will try it to see whether it suits me. Housework. Did washing. Cleaned kitchen. Humid and misty day. Marguerite Delplanque came with a friend. She wants to start back with her English lessons. Lesson with Dick. I waited for him for $3 / 4$ hour. He is never on time. Came back at $7.10 \mathrm{pm}$. 7.15-8.15 lesson with Rochette. 8.15 left for a lesson with Barland. Got back shattered. Put on pretty little shoes as I'd taken my sandals to be re-covered - but oh my heels. Three blisters and skin pulled off on the left. All bloodied on the right. I

\section{Tuesday 12 October}

What's this on the radio? All men between the ages of 18 and 40 and all single women between 18 and 40 have to report to the Commissariat de Police me (B) tomorrow. Good God. Looks like I am as good as gone to Germany despite my work permit given that I'll be unemployed by December, unless I find a teaching post. ${ }^{514}$ I'll go Saturday to see the Director. It is pointless going today because I don't want to push the idea with Kort although I will hint that

${ }^{513}$ Dilys Le Colleter (née Evans) was a British citizen married to a French policeman. Not interned, she was, however, subject to a curfew.

514 This is a reference to compulsory work service (Service de travail obligatoire, STO). Demands for more French workers increased in the summer and autumn of 1943 but by this time, civilian non-compliance was rife. 
I will be looking for something else. I'm not too keen on going to get bombed in Germany. I was wrong. It's just Italians. What a weight lifted off me. But I am not happy that Denise is leaving today. Cried. Sad. Lesson with Barland "Autobiography" (A. A. Milne). Three Fevers (Leo Walmsley). ${ }^{515}$ Good. Office all day.

\section{Wednesday 13 October}

Office. Went to Maggy Desportes place. She lent me "L'Oiseau bleu" (Maeterlinck). ${ }^{516}$ So-so. Inspected her skull (not her skull but that of the skeleton she owns). It's a brachycephalic variety (I think the dolicocephalic sort have a head a quarter longer than their width). Arrived very later for lesson with Chabert. No lesson with Dick. Bought chestnuts. Fog.

\section{Thursday 14 October}

Office all day. Went to Denise's at midday for the Saint-Loup goat's cheese to go with the potatoes. Had lunch again at her place. Lesson Beaugrand (was given pears). Chabert ( $1 / 2$ an hour) and Rochette. "Self-Portrait" ([. . .] Frankan). Showy Jew boy. ${ }^{517}$ "The Bat flies Low" (Sax Rohmer). ${ }^{518}$ For a detective novel it isn't bad. Fog.

\section{Friday 15 October}

Rent. Lesson with Delplanque. Office. Waited in vain for Denise to bring the bag for the potatoes, came at the back end of the afternoon. Lesson with Barland. Read until 2 am.

\section{Saturday 16 October}

Office. 1 and a half lessons with Chabert and Mme (Simone) Laberrie. Not fair. I only ask for 25 frs an hour. They'll probably get married. Sun. 4.40-5.10

515 Leo Walmsley (1892-1966 ). Like Winifred Holtby - another of Madeleine's favourite writers - Walmsley was Yorkshire born and based and his writing featured the moors and coast of North Yorkshire. For more on the Shipleyborn writer, see the Walmsley Society website:

http://www.walmsleysoc.org/Leo.html

516 Maurice Maeterlinck (1862-1949) was a Belgian playwright. Oiseau bleu was published in 1908.

517 'Showy Jew boy' written in English in the manuscript.

518 Sax Rohmer (1883-1959), otherwise known as Henry Ward, was a British crime writer. Some of his Fu Manchu series are available at:

http://www.gutenberg.org/ebooks/author/110 
alert. It feels like Autumn is here. It is really cold. If this evening is colder than yesterday evening. I'm bringing my cactus in. They say that Jacqueline Prévost (Piatier) is pregnant. They're saying that it is early.

\section{Sunday 17 October}

Didn't go to mass because got up too late. Villeparisis. What a bore. Granny is annoyed because I have not been for so long but damn it if I have to always be stuck with the family now. I know that Aunt is expecting me to go each Sunday now and she is not happy that I will be going to have lunch at the Delplanque's place next week. "Oh, I wanted to go to Fontainebleau". "Alright, go on then" But, oh no, that isn't satisfactory. Marcel is around at the moment and Yo has taken 15 days sick leave (???) (PS: she earns 2,500, which is good but that gives her 2,100 a month. She would go green if she knew what I was making. I started working 3 years after she did and it wouldn't surprise me if I had caught up with her). But when Marcel leaves there's only going to be me around to amuse Missy. Oh well, they can go whistle for it. I have my own life. The Roches have suggested cutting down the 4 oak trees and the silver birch and replacing them with fruit trees which will be ours and mine to take from. I would like to say yes but Godfather is furious; he has made little allotments in there, a strip for Mme Henri, a little bit for Charles - I suggested that the Roches may be able to buy after the war? Aunt was furious. In the end, the Roches seemed to be saying that they felt sorry for me because life must be miserable with a family like that. (Politics or something else?) Anyway!! Roche gave me a cabbage, a potato, a carrot, beetroot, 3 apples, 3 tomatoes. Aunt gave me a few apples and green beans. M. Laberr came with his little fox terrier Mascotte (4 months old). Came back early $(9.30 \mathrm{pm})$ and got the meal ready for today.

\section{Monday 18 October}

Office. Started back to classes - and alert!! 9.20-9.50 am. Mme Félix came back to the office, Went to Dick's lesson at 2 pm but he didn't come and so went back there at $5.45 \mathrm{pm}$. Misunderstanding but he didn't pay for the afternoon, the beast. He told me why lino is cooler than wool. Very clever. 4 pm lesson with Rochette. She is lovely. At midday had some whiting - took out nearly everything there was inside to clean them. The fattest one had three little half-digested fish inside him - but I didn't eat them. I do want to eat a fish but not one that it has eaten. Bought butter. Did my 8 hours work!! Beautiful day like yesterday but cold. Rain this evening. I heard drops running down the window panes.

\section{Tuesday 19 October}

Office all day. Denise turned up at midday - brought me some pears, the poor dear. "The fountain" (Ch. Morgan). "Psychology (Judd). Lesson Mme 
Beaugrand who gave me some butter and a ration card for the potatoes!! Lesson with Barland. Mme Kerteux has a 'girlfriend' - at her age. At any age it's a disgrace.

\section{Wednesday 20 October}

Office. I found out from Mme Broussard and Marcelle Felice how women make love to one another. Well now!! I was in tears laughing I was so shocked. I was laughing although shocked to the core. How terrible. I would have never believed such things existed even though I struggle to picture it. Marcel and Yolande came. Marcel thought the apartment was delightful and Yo, the wretch, utterly jealous. "Oh, you're always so deep in your studies" she muttered to me. It must be the 'family joke"519 - if I didn't have to work for a living I would have produced something by now but when I can only manage three or four hours a week - what to do ${ }^{520}$ As Chabert would say. Lesson with Chabert.

\section{Thursday 21 October}

Office all day. Rain. Lesson with Rochette. Autumn is coming quickly. The trees at the Val-de-Grâce are all golden and their leaves are falling, falling. Russet, crackling cloaks cover the lawns of the Parc Monceau. But again it is quite mild. $8.45 \mathrm{pm}$ and I finished my 8 hour work stint and I had dinner. I am going to be able to do some darning. I was thinking fondly today about my 'prisoner'. Is that a sign that I have one?

\section{Friday 22 October}

Did the washing. 10.30-11 am. Air raid alert. 11.15-12. Lesson with Dick. Saw Dilys. Office. Lesson with Barland at least I went, no lesson but got paid. Denise has a law exam. Rain. Letter Yvonne Disnar who is expecting a baby in April. Félix has been back for 7 months already!! Letter from Marguerite Delplanque.

\section{Saturday 23 October}

Confession. Office. Lesson Chabert. Manicure. I had intended not giving a present to Dilys - after all, she doesn't give me anything for my birthday and she is the ultimate in self-centeredness. She cornered me and was so obviously waiting for something with her little face all tensed up that I relented. ${ }^{521}$ Afterwards, she heard me whispering with her mother and she insisted that I come to

\footnotetext{
519 'family joke' written in English in the manuscript.

520 'what to do' written in English in the manuscript.

521 'relented' written in English in the manuscript.
} 
dinner on Wednesday evening when I go to look after her mother and Gaël (that's a rarity, dinner). Sent her a card with 5 cigarettes. Rested up. Sometimes, one can spend a lot of time doing one thing without getting better at it and suddenly, one day, that changes. I am pretty slow at ironing but in one hour I did 2 skirts, 2 pairs of pants, 2 tablecloths, 3 bath towels, 6 flannels, 1 pillow case, 1 dress ([. . . blue), 1 net bodice, 6 handkerchiefs and I "pressed"522 the wool jacket and the skirt I had let down!! Still raining. Knitted a little bit. Had dinner with Denise who had failed her exam.

\section{Sunday 24 October}

Mass. Went for lunch at the Delplanque's. 12.40-1.15 air raid alert. Lunch. Thick vegetable soup. Roast pork and sautéed potatoes; ham and salad in a dressing, camembert; gâteau de Savoie with jam. apple and pear tart, apéritif, red and white wine, Cointreau, coffee and before leaving, buttered pain d'épices and tart!! I couldn't manage any more. Very on edge. Met up with Denise in the morning. Poor love. Danced here this evening and then bedtime.

\section{Monday 25 October}

Office. (Heating on). Rain. Went to Dick's but he wasn't there. It is not funny now. I really must make him pay for the lessons he makes me come to do. Telephoned Felix and Jacqueline. Food ration card. Housework. Lesson Delplanque (6-7) and Rochette (7-8). Rochette stays on afterwards for at least a $1 / 2$ hour to speak to me but she is very nice. Madeleine $\mathrm{F}$ is being funny with me because she offered me butter yesterday which I refused (I had just bought $1 / 2$ a pound). She is furious and told me that she didn't know how I could eat the butter that I had because when she got some off me, it was rancid and mouldy which is not true. It was strong, I know, but I didn't make her have it and she was very short at the time. I have often noticed that she always runs down the purchases I make and has wanted me to buy from her alone which doesn't suit me because it is often dearer from her. Her butter is always fresh, but I have only had to complain once about the butter I've had from the little concierge woman. Very sleepy.

\section{Tuesday 26 October}

Office all day. Lesson Beaugrand - she gave me a packet of coffee which was very nice of her - the nice old lady. Lesson with Barland. Rain. There are, it would seem 32 ways to make love and Mme Felix and Broussard have taught

522 "pressed" written in English in the manuscript. 
me 12 of them!! It makes me blush. I am sure that I know more than Mum now. Darned with Madeleine F. Met up with Mlle Komatsu.

\section{Wednesday 27 October}

Office. Lesson with Chabert. Lesson with Dick who gave me vegetables and pasta. Went to Maggy Desportes place, she had some friends there but she was glad to see me. She lent me "Suzanne et le Pacifique' (Jean Giradoux). ${ }^{523}$ Went to Dilys's for dinner and to look after Mrs Evans and Gaël - but had dinner before. Did the right thing because a very small dish, 4 potato 'croquettes'. Potatoes the size of the palm of my hand and [.. .]) and an apple. Poor Mme Evans doesn't like George. It isn't going well. She herself says that Dilys should never have got married - well now!! Met up with Mlle Kamska.

\section{Thursday 28 October}

Office all day. Denise came by. Went to Grandfather's grave at St Denis. Train 15.30. Cemetery closes at 17.30 until 15 Nov and after then at 5 pm. Lesson with Rochette who wouldn't leave - and given that I had only eaten 400 grams of bread and butter, 1 hard boiled egg, 1 piece (small) of chestnut cake (given to me by Denise) and drunk 1 bowl of ersatz coffee, I was, by 8.30 starving, and Madeleine Rochette just wouldn't go. In the end, she did go. Lessons with Barland have stopped for the moment - shame because that means $400 \mathrm{fr}$ less a month!!

\section{Friday 29 October}

8.50 at Porte d'Orléans. Went on foot to the cemetery at Bagneux because the bus left right in front of me and I had a lesson with Dick at $10.30 \mathrm{am}$ - arrived 9.30 at the cemetery. Looked forever for the little door and then completely lost my bearings for the grave. Finally, I arrived at the information point (10.20 am!!) Was wanting Berthe Requin when it is Sidonie Delgorge!! Came back on foot to the Porte d'Orléans, $11 \mathrm{am}$. Shattered, dead tired. I couldn't pray on her grave or on that of Grandfather. The body doesn't mean anything to me at all. Might as well put flowers on an old pullover they used to wear. Because I love the soul of the person first and the body second because the body belongs to the soul. The human body is not so beautiful that it can be loved just for its beauty. An animal, maybe, but I'd rather a living animal than its hide. I like fur

${ }^{523}$ Jean Giradoux (1882-1944). Suzanne et le Pacifique was first published in 1921. The 1925 edition published by Éditions Émile-Paul Frères is available via the digital collection at the Bibliothèque nationale:

http://gallica.bnf.fr/ark:/12148/bpt6k80734v 
gloves, soft and warm - that's flesh - but standing over a square of earth saying "underneath there, in a box, are grandfather, godmother" - they are not as I knew them. Perhaps there are only bones but I doubt it. They have died too recently. It would take 10 to 20 years for that to happen. So, strips of green or blue flesh liquefied and evil smelling. A shapeless mush which would be disgusting to see eaten through by fat white maggots which shimmer with a yellowy sheen they are so fat and squidgy. Yes, indeed, I prefer their souls. I loathe cemeteries. I wanted to go to see Uncle Henri and Cousin Giselle but because I didn't know the date of their death will give the money to Aunt. Office. Denise came to get paid. Went to Felix Disnar's to get potatoes. I had put a hat on and made myself up. I think I made quite an impression on him. I must have been 15 when I saw him the last time - an awkward little girl with two pig tails down to the waist. I had an eye on those $15 \mathrm{kgs}$ of potatoes (but don't say a word to Yvonne) And if ever I need something ... !! (apparently Mme Zéau is very [...] and very pessimistic). Tired out with $5 \mathrm{~kg}$ of potatoes one side and $10 \mathrm{~kg}$ the other. I must be looking pretty lovely ("aggressive" Kort says) because I was followed in the métro. He lost me at Odéon. ${ }^{524}$

\section{Saturday 30 October}

Holidays, holidays. Got up at $9.30 \mathrm{am}$. Dreamt that I was married with a baby and my husband didn't want me to go out or to study. He burnt all my books. One day I decided that I had had enough. I left home with the baby under my arm. I didn't know that my husband was a sentry on the road to the town where I needed to go to get to the station. He saw me and he jumped into a car. He caught me up and knocked me out and when I came round he told me that I was ill and had fainted. He hurriedly tried to make another baby so that I couldn't leave and I was begging my mother to get a midwife so I wouldn't have to give birth on my own when I woke up. That one was even better than Thursday's dream. Dilys, an Englishman and I were on Scarborough Bridge. There were Germans on the end of it near Leeman Road. I went ahead to give Dilys and her companion time to escape but we were surrounded. I don't remember the rest of it very clearly except that Dilys, in trying to escape, threw herself in the Ouse, then got into the lift at 322 rue St Jacques. I was denying everything. There was also something about biscuits and meeting Ruth in the métro which had taken flight and was going to the most amazing places. Gaël was also mixed up in it all. I should recount my dreams straightaway.

${ }^{524}$ Written alongside the entry of 29th October, 'Grave of Godmother Sidonie Delgorge 18 September 1942. 65th section, 14th row. Number 4. Cemetery Bagneux. Métro: Porte d’Orléans. Bus. Number 128.' 
Lesson with Chabert, but I am losing my mind. I went at 12.45 instead of 1.45 !! Then, as he was 40 minutes late I waited - 14.40. The hotel cat is hilarious. He opens the office window by pressing his paw on the latch - and he carries his tail in a curl like a Pomeranian dog. Cleaned from top to bottom and in a hurry because Jacqueline Eichhorn came to lunch. When it comes to it, her job doesn't pay much. OK, she earns 2,400 fr but she works 5 days a week from 7.45 to 15.15 non-stop because she is in charge of the canteen. Thursdays off, at least 4 Thursdays out of 5 . Not so good. ${ }^{525}$ The office is still better than that. She is very nice - and she certainly enjoyed my tea!! At the moment things are not going too well with Dilys. She thinks that Gaël is a little devil and told Dilys so. So that means she won't be able to cross the threshold for a long time. Mad F came round to chat for 2 hours. Letter from Aunt telling me to bring a jacket because we will go to the cemeteries at St Denis and Bagneux. Phew. Am I glad that I have already been. And given that I have 3 lessons on Monday ... . !! Cold.

\section{Sunday 31 October}

C. Mass. Villeparisis. Oh, not good. They are very nice but I feel like a fish out of water. Went to see Jacqueline Charles (who is bored stiff) and went to see M and Mme Henry to get back the bits of land that Godfather lent them. Gave the document to Roche about chopping down the trees to have fruit trees. I hope that I haven't acted against our interests. I hope that my parents will approve. Knitted. Aunt is furious that I have already visited the cemeteries. M. Laberr came over. His dog Mascotte is a little treasure. I noticed that Yolande was trying to cut me off with insidious questions. Why do they think that I am always lying? She's the one lying with her 400 warrants to do a day!!! Got some supplies from Roche ( 1 cabbage, 1 pumpkin, a few apples, leeks, potatoes et some dahlias). Villeparisis is a filthy godforsaken place, everyone stabs their neighbour in the back and runs them down. Godfather is pro-German. Can't believe it. I've rarely witnessed it to such an extent. As I left, broke the news that I would stay 2 Sundays and then have the $3 \mathrm{rd}$ at home (not quite true - hope to have all 3 at mine). Aunt half-smiled, half-grimaced. They are hoping to get me over there now that Marcel has gone so that Yolande is not on her ownsome. Beautiful sunny day, but cold. Saw new crescent moon. Party at Villeparisis.

\section{Monday 1 November}

C. Mass. Peaceful and content today. 10.30 lesson with Dick. Afternoon, stuck down photos done and knitted. Delplanque didn't come. Rochette stayed over half an hour after her hour. She is terribly talkative but very nice. Read a bit

'Not so good' written in English in the manuscript. 
of "The Fountain" by Charles Morgan. ${ }^{526}$ It will take a lot of time to read it. It rained a little. The book is alright but you have to read a few lines and then mull over them. It is cold but I only have a wool top and a thin blouse on. Obviously, because I am sat still all day I need to be wearing a dressing gown or a cardigan. Quiet and lazy just as I like my days. Listened to a lot of concerts including Haydn's number 104. It's not my favourite but it took me back to University. What does one really need in life? Time (ie: not to have to go out to work), a garden, music and a pet. And lovely Mummy. I'm going to go to bed early because I have much dreaming to do. It has been such a long time since I allowed myself a day's holiday. Tomorrow afternoon I'll be forced to go out oh dear. ${ }^{527}$ But I've bathed in silence and solitude and am refreshed. What an oasis!!

\section{Tuesday 2 November}

Stayed in. Was getting ready to go and give a lesson to Chabert when he came to cancel. Darned. Lesson with Beaugrand who gave me a slice of meat and a little bit of butter which turned out to be margarine. Potatoes from Delplanque arrived.

\section{Wednesday 3 November}

Office. 1.45 lesson with Chabert. Perm. It's great, good cut.

\section{Thursday 4 November}

Office all day. Rochette didn't come for lesson. Went to the Red Cross. "Still no news despite sending monthly messages. Félix on POW leave. ${ }^{528}$ Yvonne is expecting a baby. The Zéau family send warm wishes. Christmas greetings, Happy New Year. Am in excellent health. Hugs". Jacques brought the potatoes

${ }^{526}$ Charles Langbridge Morgan (1894-1958). English playwright and novelist. The Fountain was published in 1932. His 1936 novel Sparkenbroke is probably his most famous and most successful novel. Hélène Berr mentions it in Journal (and one of her friends carries the title as a nickname). For more on Morgan see:

http://www.charleslmorgan.org/index.html

527 'oh dear' written in English in the manuscript.

${ }^{528}$ Some French POWs - those with young families and those with skills needed in France - were allowed to return to France to work. The scheme was called 'Congé de captivité. An interesting resumé of this arrangement and other fascinating facts about the Occupation outside Paris can be read at: http://www.memorial-quineville.com/index.asp 
up for me $(50 \mathrm{~kg})$. I smoked 2 cigarettes to help me to concentrate on studying but nothing doing.

\section{Friday 5 November}

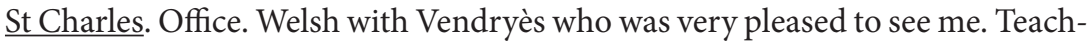
ing job flop. ${ }^{529}$ Pity. I love J.V. He is adorable. It is a shame that he is so old. I

\section{Saturday 6 November}

+ Office. Kort invited me to his place on Sunday!! Denise is going to have a perm done. She talked to me a lot about Guy. Met up with Giselle du Mesnil who is very nice but who is dropping us. Met Kokinakis in the métro. Mme Berasalus (from the Annonciade convent) is expecting a baby. Have I already said that Mme Roussel is expecting a baby at the end of June. And that Mme Caillat has a little boy François? Got back at 13.05. 13.30 lesson with Chabert. $3 \mathrm{pm}$ manicure. Mrs Evans is very ill - abscess on the lung. Went for tea and spent the evening at Dilys's to keep her mother company. 10.10 to 10.42 air raid alert.

\section{Sunday 7 November}

Mass. 9.45-10.50 alert. Went to Dick's but no lesson. Darned stockings. Went for tea to Kort's who was charming. Mme Kort was too. They have a daughter who is 25 . He's never seen her!! Very cold. I

\section{Monday 8 November}

Office. 1.30. Lesson Chabert. Registered at the Sorbonne. 5.30 lesson with Delplanque. Sent Pneu to Rochette asking to give the lesson at her place as I have a carbuncle on my behind. The fees at the Sorbonne - phew!! - 540 francs to register. I

\section{Tuesday 9 November}

Office all day. Had lunch at the foyer féminin - very so-so. ${ }^{530}$ Wrote to Yvonne Disnar, Hélène Barland, Aunt V. 5.45 lesson with Dick who, as he was leaving, shook me by the shoulders. Why? Went to the Dougall's place to get the address for the school. Dropped in at Dilys's. Her mother is much better. Lent

\footnotetext{
529 'Teaching job flop' written in English in the manuscript.

530 'very so-so' written in English in the manuscript.
} 
her "Om" (Talbot Munday) 531 "Hans Christian Anderson. by himself". Wrote to Charles-Gaby. Lesson American civilisation (Le Breton).

\section{Wednesday 10 November}

Office. "Visite aux Américains" (Jules Romains). ${ }^{532}$ "Fermentation" (Steinberg). Paid fees. Breton. Welsh. Bachellery. Two new arrivals. Mlle Le Hir and M. ${ }^{533}$ Maggy Desportes was very peeved because Bach. interrupted our conversation to introduce Mlle Hir to me but not to Maggy. 3.10-3.25 air raid alert. Bach. went with me to Gay-Lussac. 5.30 lesson with Delplanque. In the morning left without having eaten breakfast and at midday scoffed 3 sautéed potatoes but sick this evening after 2 sautéed potatoes so went to bed early (10 pm) to make up for the other days when I stayed up until 1-2 am.

\section{Thursday 11 November}

Office all day. Went to the community canteen. Aunt Marie phoned. No news from André for a month. 5.15 lesson with Beaugrand. Denise came this morning. Evening 7 pm lesson with Rochette. Had coffee at Madeleine F's. Her bit of rough was there and paid me lots of compliments - that I didn't look 25 but more like 22 because I didn't have wrinkles etc. I've already found an admirer in Resco. . . .! Letter from Hélène Barland. Wrote back. Wanted to study but it is already $11.15 \mathrm{pm}$ and I have to get up tomorrow - I am tired. I haven't written my diary and I don't know if I am on my head or my heels chasing to the office, to lessons, to the Sorbonne - sleeping in raggedy sheets and eating snacks as and when. It will settle down. Tomorrow and Saturday to get through and I will, I think, be able to get some balance back. It is cold!

\section{Friday 12 November}

Went to see Aunt Marie. René has bought a restaurant 4 rue du Cherche-Midi. It's St René day today. Didn't notice. Bit of a slip. Never mind. André injured in 3 places:- foot, cut on the face, knocked over by a dustcart. Welsh with Talandier. Vendryès. Office. Had brolly nicked. Really annoyed. Telephoned the Academy but can't come. Brought back potatoes. Lesson with Dick. Lots to say, but no time.

${ }_{531}$ Talbot Munday (1879-1940).

${ }^{532}$ More on Jules Romains (1885-1972) and Visite aux Américains can be found in Dominique Viart's 1996 study Jules Romains et les Ecritures de la simultanéité: Galsworthy, Musil, Döblin, Dos Passos, Valéry, Simon, Butor, Peeters, Plissart.

${ }^{533}$ Left blank in the manuscript. 


\section{Saturday 13 November}

Office. Had a 10 minute lunch. (beef 90 g, 2 raw carrots, $200 \mathrm{~g}$ of bread, 2 sugar cubes). Lesson with Chabert $1.30 \mathrm{pm}$ (lesson half an hour). Went in the pouring rain and without a brolly looking for the "Ambassades" language school. Found it but there was no one there. Came back with a migraine. Had tea with Sabine Vialla. Did some studying. Rain. Quite cold. Migraine.

\section{Sunday 14 November}

Mass. Housework. Did some darning, Worked very hard but tired out. And I still have this migraine. Beautiful weather and windy this morning. Rain in the evening. The electrician no longer wants to exchange eggs for wine. That's a pity. I'll drink it or I'll find another swap. Rheumatism in my right hand.

\section{Monday 15 November}

Office. After lunch with Resco, walked to the Louvre. 2 pm. Lecture by Lantier on Celtic archaeology. Registered. Saw Maggy Desportes. Went with her to the Magasin du Louvre. Came back on foot via the Latin quarter. 5.30 lesson with Dick but didn't give it. 5.30 lesson with Margaret Delplancq. Paid for the potatoes - broke now. 7 pm lesson with Rochette. 9 pm lesson with Nicole Capon - I got lost it was so dark but everyone was very nice about it. Got back at $11 \mathrm{pm}$. Darned stockings until $1 \mathrm{am}$. Rain.

\section{Tuesday 16 November}

Office all day. Went to Le Breton's seminar. 5.15-6.45. Lesson with Dick. $8.30 \mathrm{pm}$ lesson with Chabert with Mme Laberrie. I don't think that this is fair, doing both of them for 25 francs. He surprised me by telling me what I was doing at the Hautes-Etudes - but he had bought the directory where it says that I do literary analysis. I have to confess that I was quite proud and flattered by that. Letter from Cyla which pleased me enormously. Talked with Mad. F. and decided that I would not go for tea at Dilys's. I don't have the strength to refuse to do what she is going to ask me to do. I am sure of it now (I have been for several days). Oh. I am so feeble and cowardly and so weak even though I am stubborn. I've a real pride although not always about the right things. Good that the mention in the directory and the letter from Cyla have bucked me up. Cold.

\section{Wednesday 17 November}

Office. Eager to buy the directory. 1.30 pm Half an hour lesson with Chabert. 3-5 lesson with Bachellery. Hibernating in silence at home so that Dilys won't get an answer if she comes to try again. It is very cold; bought draught excluder 
but impossible to find any tacks. If I still can't find any I'll have to go flirt with the cobbler. If that fails, then I'll ask Mad. F. I can't put the electric radiator on because I will put it on tomorrow for a lesson and I've already gone over 3. It really gobbles up a lot this little radiator. When it comes to it, I am tough enough to deal with shortages, physical and mental collapse, air raids etc but not with the danger of being picked up. I am not a very good liar either (other than lying to be polite). Cold but I am going to study.

\section{Thursday 18 November}

Office all day. Lesson with Beaugrand. Lesson with Rochette. Very cold but going to study.

\section{Friday 19 November}

Welsh with Vendryès. Went to Dilys's to get books on American literature but not enough time to take them away. Office. Lesson with Dick (didn't come). Letter from Cyla which I was very pleased about.

\section{Saturday 20 November}

Office. Am. Lit. not open. Lesson with Chabert. Manicure. Pneu from Aunt. Letter from Rochette. Card from Resco. Very cold. Put down the draught excluder. Had tea at Dilys's.

\section{Sunday 21 November}

Mass. Darned. Wrote to Cyla but can't find her address. Cold. Put the electric radiator on. Ill, sick. Weekend already over more is the pity!!

\section{Monday 22 November}

Office. Lesson Lantier. Telephoned Mlle Capon. Lesson with Capon at mine. Went to Rochette's for lesson and stayed for dinner (pork, beefsteak, roast beef, chips). Her father sorts out the stamps. ${ }^{534}$

\section{Tuesday 23 November}

Office all day. Lesson with Dick. Had some rabbit (1/4).

${ }^{534}$ Unclear what this means. 'soccupe des timbres'. Looks after, collects, sorts out. It may be a reference to Resistance activity or possibly to stamps given to Madeleine in payment for lessons. 


\section{Wednesday 24 November}

Office. Lesson with Chabert. Lesson with Bachellery. Lesson with Marguerite Delplancq who brought handkerchief and sent a card for St Catherine's day!! Had dinner at Dilys's who gave me 3 eggs and some lard. Looked after Mrs Evans.

\section{Thursday 25 November}

I am a Catherinette!!! At the office they gave me a brooch, orange blossom perfume spray and a carnation. Mlle Kerjean gave me an apple. I was very touched by all this kindness. They are really great at the office. Phoned Aunt Marie. Lesson with Beaugrand. Lesson with Rochette who brought me a bouquet of orange tree blossom (imitation wax ones!). Dashed off 8.30 pm to Renés. André was there, back from Germany. The poor love. As thin as a lat. You could count his teeth through his skin, trembling all over and silent. René seems older than he is and he knows how to order people about.

\section{Friday 26 November}

Lesson with Vendryès. Nearly arrived late because woke up at 9.15 am (didn't hear the 5 am anti-aircraft fire which shook the house!!) 10.20-11.45 alert but didn't go down. Met up with Madeleine Lavelle who has cut her own hair. Office. Alert. $1.30 \mathrm{pm}-2 \mathrm{pm}$ lesson with Dick - was wanting to give him the sack $^{535}$ but he was so charming and paid in advance and so I didn't.

\section{Saturday 27 November}

Office. Lesson with Chabert. Dropped by at Dilys's. Wanted to do my washing which had just boiled but Mad. F. came to chat for 2 hours!!! That buggered that up. So studied instead.

\section{Sunday 28 November}

Didn't go to mass because got up too late. Went Villeparisis with bad grace. Gave flapjack to Yolande which she was very pleased about I could see and everyone charming as a result. Poor Granny poured out her memories. What a sad childhood she had. Her brother committed suicide (he didn't have nerves of steel like Granny). But there must be some hereditary blight. The father of Granny's Grandmother abandons his children but comes back to be kept by his daughter (Granny's granny was a baker). Granny's father leaves too. And if one looks at the wreck Henry is (her son) and the obsessive that is Aunt Violette only Granny and Yolande are spared. Poor Godfather and Granny trying to sell

535 'sack' written in English in the manuscript. 
things to get some money. I brought three books back to get them valued. Poor Granny. What sort of life has she missed out on?

\section{Monday 29 November}

Office. Lecture with Lantier. Bought birthday and Xmas present for Gaël. Rain. Wind. Feet hurting. Manicure. Bought butter. Lesson Rochette.

\section{Tuesday 30 November}

Office all day. Bad day because felt angry. Everyone has got a pay rise except me. Said to Mme RB. "Why?", "Student" "Why can't I be like Denise?" "If you can find someone with as much influence as Denise did then I wouldn't say no but I can't do anything myself". Told Denise who will ask Robert Guillou as soon as she sees him. I will take the law into my own hands and I will go to see Moignard. If that doesn't work I'll turn my guns on Guillou. I don't see why I don't get perks too. I'm not a penny pincher like Dilys but Christ I've had enough of being taken for a ride. Nearly cried but sang a song to myself. Lesson with LeBreton. I started to feel a little better. Lesson with Dick. On the way there I saw the crescent of the new moon so all is well. I love it that the view is so pretty in the morning when I get up - the roof slates all silver and grey, the grey of the sky, the grey mist - all of it is alive and in harmony with the warm rain which has been falling against the window panes. I feel as if I have melted with tenderness looking at this composition. Did the washing this evening. Did it slapdash but didn't want to finish it at midnight. Made a list for Christmas presents - 800 frs!! Decided - and my salary confirms it - no presents for those who are older than 7 years old - but I would like to give one to Cyla. Oh well, I am going to go to bed!!!!

\section{Wednesday 1 December}

Office. Mme Félix got on my nerves by asking where to catalogue every single item. I said to her, "Well, read it and see! How will you get on when I am not here?" Kort heard all this and since then he has been thrashing around trying to get me a pay rise. Before, he didn't bother in the slightest even though he knew that I was still on 1400. He told me not to do anything - I said: I am going to see M. Moignard this afternoon." "Don't do that", "Yes, I am going". Alert 10-10.20 am. They are messing us around. Lesson with Chabert. "La Civilisation du Renne" (Leroi-Gourhan). ${ }^{536}$ "Manuel de recherches Préhistoriques"

${ }^{536}$ André Leroi-Gourhan (1911-1986) was a French archaeologist. See Vincent Albert's 1938 review of La Civilisation du renne (1936) in Revue des Sciences Religieuses, tome 18, fascicule 1, 1938. pp. 143-144.

www.persee.fr/doc/rscir_0035-2217_1938_num_18_1_1753_t1_0143_ 0000_2. 
(Soc Préhist). Went to Moignard's - of course, my suspender breaks just before seeing him, that made me think of my first kiss. Saw Moignard, he is not against me working from home, Mme RB doesn't have the final say. Obviously, Kort is going to be furious but given that it will be great for my studies I will stick it out as long as possible. ${ }^{537}$ If not, I will get something else. I have been so comfortable doing that in the cosy cocoon of a little routine. Why shouldn't I have money? Why can't I study as I like to study? I am two years behind with my studies. But, I've been ill. I've been more ill than I wanted to admit. When I think that not a day has gone by that I haven't had dizzy spells, felt sick, pains in the side, problems with my vision etc. And, now - touch wood - a glowing complexion and good health. Well, beddy-byes ${ }^{538}$, if I don't, I won't be able to get up tomorrow morning; it is hard when it is dark. When it is light, I can easily get up at 6 am (German time 4 am in the sun). Lesson Delplancq. Letter from Capon about the time of the lesson on Friday. Mme Le Beyré wants me to use my influence with Vendryès to help her; but she has a good case. She doesn't need me. All the same, I promised that I would put a word in for her. Meeting with Moignard. Didn't go to Bachellery's lesson. He must be furious. He counts us in like the Hotel accountant used to count the number of pigs - but on Friday I will spin him a yarn even if it means him getting worked up. I think that he is "strongly attracted". 539

\section{Thursday 2 December}

Oh dear! ${ }^{540}$ What a day. I tell Kort that I am going to work from home and he flew into a rage. "I forbid you to leave my department Mademoiselle. I categorically forbid you to work at home". Then he pulled on the heart strings wringing his handkerchief "How could you do that me. I've trained you up for two and a half years, etc, etc". At one point I thought that he was going to cry, his face went all wobbly and he started to blow his nose violently'. It went on for about two hours until I went down to see Mme RB who said "that's absolutely fine, marvellous. You've done right there etc". At 2.30 pm, another carry-on. Kort and I went to see RB - "Who told you that you could involve me?" "But I didn't involve you!", "Yes, you did. Moignard telephoned me. You're just a rotten little wretch who is jealous of Denise Pedron" and he went on and on. I just stared at him wide eyed and open mouthed. In the end, it is agreed that I will work two mornings and won't be able to leave before finishing the file run - which will take at least 15 days Kort says. I leave and cry my eyes out. He comes back up and talks to me as if I am some kind of dangerous animal then, having forced me to look up to take some document from him, he sees my red eyes and then

\footnotetext{
${ }^{537}$ Writes 'Je vais sticking it out le plus possible' in the manuscript.

538 'beddy-byes' written in English in the manuscript.

539 'strongly attracted' written in English in the manuscript.

540 'Oh dear' written in English in the manuscript.
} 
drama. He rushes to the window, blows his nose loudly and he says very gently that I have worked enough, that I can read "Toute la Vie", "La Semaine" - and so I do. What a carry on!!!

Went to the Red Cross. "Still no news. Uncle André has come back from Germany. Health is good. Sending lots of love. How are Nils, Aunt Marguerite, Jeanne, Marguerite? Birthday wishes to mummy. Hugs and kisses”. Lesson with Mme Beaugrand. When I got in, going over and over the day in my head, I found a parcel for me from Portugal!!' I was ecstatic!! 5 tins of sardines - I opened one of them straight away. Yum yum. They are so, so good. Gave 3 to the concierge 2 and a half to Mad. F and given that it was Rochette's lesson, have given one to her too. I had one and a half left. They are absolutely delicious. That cheered me up. I don't mind having days as horrid as that so long as I have a parcel waiting for me in the evening. "Nightingale Wood" (Stella Gibbons) ${ }^{541}$, "The Dolliver Romance" (Hawthorne). ${ }^{542}$

\section{Friday 3 December}

Welsh with Vendryès. Office. Kort." I want you to get parcels from your parents, of course I do, indeed, I hope that you do, from the bottom of my heart but let's get back to business, have you decided which days you are going to come in?"Righty-ho!! Lesson with Mlle Capon. Letter from Jean-Claude Poussif asking for a lesson. Most importantly, got a message from the Red Cross written by Mummy on the 23 August: "Gilberte died. Aunt Germaine is staying with us for the moment. We are all well. Be patient. Our thoughts are with you. If we have bad news we will send it via the Red Cross. Kisses. Mummy" - this was a response to my message of the 10 June.

\section{Saturday 4 December}

Office. Started to copy the index. I rushed so much I felt sick. Lesson with Chabert. Read "Nightingale Wood" curled up against the radiator after ironing. Good evening. Peeled some mushrooms then went to bed. OK.

${ }^{541}$ For more on Stella Gibbons (1902-1989) and her writing, including her most famous novel, Cold Comfort Farm, and Nightingale Wood, referred to by Madeleine, read Sam Jordison's Guardian 2013 feature:

https://www.theguardian.com/books/2013/dec/27/cold-comfort-farmstella-gibbons-novels-reading-group

${ }^{542}$ Nathanial Hawthorne (1804-1864). Dolliver Romance is available at: http://www.gutenberg.org/ebooks/7119 


\section{Sunday 5 December}

Mass at the Val-de-Grâce. Got up late. Air raid alert 12-12.15. Spent a nice day at the Delplancqs'.

\section{Monday 6 December}

Letter from Aunt inviting me to go with her to Chatêlet on Wednesday. Letter from Gaston Boyelle asking what the terms are for lessons. Office. Kort is making it as difficult as he can for me to finish the index - asking me one thing and then another, interrupting - the pig. Lesson with Lantier. Did a bit of cleaning. Wrote to Poussif. Lessons with Delplancq and Rochette.

\section{Tuesday 7 December}

Office all day - copied up the index all day and even through the lunch hour. I don't want to spend 15 days doing it. Lesson with Dick.

\section{Wednesday 8 December}

Office. Lesson Chabert. Welsh Bachellery. Mme Desportes wasn't there. Mlle Le Hir is in love with Bachellery. She walked part of the way with me to talk to me about HIM. She's also very curious about me. The girl is childish and stupid. Maggy Desportes says - "Vendryès's sense of humour goes right through them like an X Ray". That is very accurate. Maggy has a heavy cold. Katy has recovered well and Izou is a sweetheart. Went to Chatêlet earlier, got Aunt's pneu in the evening. "Valses de la France". Fairly pretty but very silly. The fellow who puts a settee cover over himself and pretends to be a settee was quite funny. They've not been to take the electricity reading. Will I get cut off? Furious.

\section{Thursday 9 December}

Office - or at least, on with the index all day!! Finally finished it. Ner ner finished! Took a week. Crowing about it! "Sally Lunn" (Leo Walmsley), "Abraham Lincoln (Morgan). Didn't have a lesson with Beaugrand, not there. Lesson with Rochette. Saw Denise.

\section{Friday 10 December}

Welsh with Vendryès. Rather, Irish for 2 hours. Housework. Did it very well - dropped everything, broke (cracked) the little Delft pot and broke cactus planter. Lesson with Capon, Dick, Poussif. Wrote to Boyelle. 


\section{Saturday 11 December}

Office. Travelled with Mlle Roussel. How stupid she is about loving Claude. She turned down a librarian job - 3000, was promised 5000 at l'Odéon. $9^{1 / 2}-12,2-6$ - because wouldn't be able to see Claude at lunchtime!!! Lesson with Chabert. Snow and ice. Saw 2 horses lying on the ground. It made my stomach turn over. For a week I have felt continually sick. I have found out what it is. Quite simply, it is the cold because we do not have any heating. Confession with a very passionate young priest. Made crêpes with jam and tidied up papers. Very, very cold. I am going to put the radiator on because I would like to do the work for the office which I have to take back on Tuesday. Letter "Aide Social aux Emigrants" ${ }^{\prime 43}$ with a message from Granny dated 9.11.43. "We are still in good health and sending hugs. Would like recent news. From all the family Gabrielle Blaess". So I'm not the only one not to receive any news. The typed message from the bureau declares that it would like to know whether I am still in good health, if things are relatively problem-free at the moment and, in general terms, what personal information I would like to be sent. All that is very nice but I could have been dead and buried in the three and a half years I have been alone here. But, I am going to go if only to complain that I haven't had any news.

\section{Sunday 12 December}

C. Mass. Villeparisis. Very cold. Had to wear a little cloth hood - looked like a baby in a bonnet. Was awake from $3 \mathrm{am}$. My last wisdom tooth is hurting. Took the tin of sardines to Villep. ${ }^{544}$ God I am bored there!! It's awful - and the worst of it is that I am starting to despise them! Godfather has taken against the English - before he was as Communist as they come, then the Germans were terrible and the English were darlings. Now the English are bastards etc etc. One side only has to shout long and loud enough and he falls for it and is even more extreme than before. It doesn't matter whether one is pro-German or pro-English I've got friends with both opinions, even three opinions but Good Lord don't change colours according to who yells the most. Marcel really puts his foot in it - or perhaps he does it deliberately? Very sweet towards me. I take my hat off and he says "what a beautiful head of hair she has, so much of it and so soft, my goodness" - Yolande glares. She'd done herself up to look "beautiful" today but looked as hard faced as anything. With a bit more work, shed look splendid. Aunt pulled a face when I announced that I would only come for one day over Christmas - I wouldn't be able to stand the atmosphere. It isn't their fault but it bores me. In the train we chatted about outfits and Aunt said to me miserably - because I had gone on about how wonderful the Delplancqs were

\footnotetext{
${ }^{543}$ Association supporting emigrants.

${ }^{544}$ Villeparisis.
} 
etc - "Yolande needs to go out more. Other than you and Marcel there is no one she can have fun with." I have been alone for three years and I have turned down invitations (turned down 4 invitations for Christmas - Dilys, Delplancq, Rochette, Bachellery) and Yo, for 20 years, hasn't had any friends. Mum always said that she has found it strange that Yo didn't have any friends - I did too. But I am not going to introduce her to my friends. They wouldn't find anything to talk about. Now, having been nice and catty ${ }^{545} \mathrm{I}$ am going to take myself off to bed. Aunt wants to make a white rabbit fur jacket for Yolande. Et nunc, dixit Pepys, alias Magdalene - "and so to bed". PS. Marcel is leaving tomorrow for Chef du Pont. He is barely earning 1800 a month every second month. Not so good. ${ }^{546}$

\section{Monday 13 December}

First day of the new routine!! Bad start getting up at 7.45 am instead of 7.15. Because I did the housework I started to work at 9.30 instead of 9 am. Very cold. Went an hour without putting on heating but couldn't stick it out and so put it on. Lesson with Lantier. Last one in the 3 month block. He will start again on the 3rd of January - it is a shame that he is stopping so early. He reminds me of Noble. Went to 391 rue de Vaugirard to the "Aide sociale aux Emigrants". It is in a big building for foreign workers. I was able to write a lot. I wrote the following by and large: "Madeleine Blaess sends a message to her family every month and is worried that she only receives an answer every six or eight months. She is well. She's arranged her hours at the office so that she can start up her studies again. Her Uncle Joseph is very pleased with her about this. Her Uncle André is back from Germany. He has been injured three times but not seriously and is now well. Yolande has got her permanent post. Félix has been released. Yvonne is expecting a baby. All the family is well and sends warm wishes. Most of all I would like to have more regular news. Kisses and hugs". Well, it was something like that. They say that they will send it. I hope to God that they will and that my request for more news will come to something. I also put that I received a parcel from Portugal with 5 tins of sardines. Waited pointlessly for Marguerite Delplancq. Her pneu arrived at 8 o'clock it was probably [...] like that sent by Mme Beaugrand which arrived yesterday and which was given to me today by the concierge who saw me coming down. Washed a few smalls. Denise came to ask me to come on Sunday perhaps. She also asked whether I could give her and Guy the keys to my room on Wednesday and Friday afternoon. I asked her whether she wanted clean sheets. I probably shouldn't have done but it happened without me being able to say no. All he has to do is take her to a hotel. I am not a brothel keeper - or whatever the word

545 'nice and catty' written in English in the manuscript.

546 'Not so good' written in English in the manuscript. 
is for someone who runs a place where people come on dates. And if the deed hasn't already been done, I would rather that it wasn't done at my place. I don't say anything to her about it because that would be pointless. In the end, she's going into it with her eyes wide open. And, as for him, what a little boor. She's clearly a mistress on the cheap. Lesson with Rochette but she started to cry and she stayed for 2 hours crying away because at home her parents don't care about her faith which upsets her. It's probably heroic to angrily defend one's faith but I find that shutting up and just doing what one wants is more effective because that doesn't make people angry and because what's done is done and they can't do anything about it. Well, what a carry on. I am hot and cold. I really should have a big wash for the medical tomorrow but I will do it tomorrow morning. It is already quarter to 11 and I don't know when I will get to bed. The days are over when I studied until 2 or 3 oclock in the morning and got up at 7.00. If I am not in bed before 11.30 then it's a disaster because I can't get up before 7.30 and it's the office tomorrow. I did my chores this morning. That'll give me more time obviously.

\section{Tuesday 14 December}

Office. Marcelle Felix has got a new rich lover. What a whore!!! It is cold, cold, cold and still no heating!! Came back to work here for an hour before leaving for the medical examination and froze to death. I really must buy myself a thermometer. Went to look at the electricity meter. I can't see whether or not a reading has been taken but in any case they won't cut me off. Medical examination. Weight is stable. But had a bit of a shock with the $\mathrm{X}$ ray. There's some sort of calcification in the right lung. I didn't really understand I was so shocked. Is it serious - serious enough to have the right to a card for extra rations? ${ }^{547}$ Anyway, it's a great excuse not to have to go very often to Aunt's. In July there was no trace of anything. But I have always known that there was something there because when I twist my chest area without moving the lower part of my body (from the waist downwards) it gives a sort of "rasp, rasp", like there is a sort of rubbing and it takes me a few minutes to get my breath back. Well, anyway, I'd be amazed to have anything serious. Other than when I am cold, I have never felt so well - if only I didn't put on so much blubber. I'm going to start up the gymnastics again to see whether that makes a difference. Lesson with Dick and Poussif. Red Cross membership.

${ }^{547}$ Calcification was a sign of TB, which was endemic during the Occupation. Yolande, Madeleine's cousin, contracted it, as did Georges, Dilys's husband. This appears to have been a false alarm. It is interesting that Madeleine's first thought was whether she would qualify for extra sickness rations as a result. 


\section{Wednesday 15 December}

Very cold. Worked on the cataloguing. Frozen stiff. Welsh with Bachellery. Felt strange to be in the warm. Letter from Cyla. So, it seems that Curlylocks ${ }^{548}$ will be in Paris. I haven't see her yet. Cyla is really fantastic. I would do anything for her. She is really charismatic. After a simple dinner - a helping of soup and vegetables, I felt really poorly, felt nauseous, head bursting. Fell into bed at 8.30 $\mathrm{pm}$ and despite trying to work, I fell asleep straightaway. Woke up at $11.30 \mathrm{pm}$. The radio was still on. Switched everything off, opened curtains and went back to bed. Ice on the panes.

\section{Thursday 16 December}

Stayed in bed until midday but studied between 9 and 12. Pneu from Boyelle. Took wine to Mme Felix. Lesson with Beaugrand, Rochette.

\section{Friday 17 December}

Welsh with Vendryès. Bachellery has invited me over for the day after Boxing Day. What a bore that is. Lesson with Capon, Boyelle (what a disappointment. Thought it was a 19 year old kid and it's a middle-aged man). Dick (he is impossible, he plays around all the time). Poussif, Marcelle St Denis over at Mad. F's. Poor kid has got to go back to the mountains. She is thin. She hasn't got long left! ${ }^{449}$

\section{Saturday 18 December}

Office. Denise came to confirm that it is dinner at her place tomorrow. My word but she is a chatterbox so didn't have lunch until $2 \mathrm{pm}$. Did some cataloguing. Went to Mlle de Fricourt's to see whether I can get more rations because of my lung. I feel very depressed. It's the cold. My back and lungs are hurting. The cold must have got into them. I am very, very anxious about Mum and Dad. Are they ill? So many deaths, 1400 last week. Dad is susceptible to 'flu and Mum isn't that robust. I am horribly worried. When I think about it, I tremble and get a lump in my throat. No more sugar nor butter. I will have to find some on the Black Market but I have no money. I don't care about what happens so long as Mum and Dad are not ill. My feet are like blocks of ice - as soon as I have some money I will buy myself a hot water bottle.

\footnotetext{
${ }^{548}$ It is unclear who Madeleine means here.

${ }_{549}$ Possibly a reference to TB.
} 


\section{Sunday 19 December}

Mass. Spent the day at Denise's - drying dishes!! Guy came for afternoon tea. Torrential rain. Bored out of my mind.

\section{Monday 20 December}

Woke up at $9.20 \mathrm{am} ! !$ Ashamed about being so bored with everything. Darned girdle. Started the housework. Splendid weather. Window open 'til $2.30 \mathrm{pm}$. 10.10-10.25 air raid alert. 3.30-4.15 pm another alert. Cleaned the copper pans. Lesson with Boyelle and Rochette. Chilly evening.

\section{Tuesday 21 December}

Shortest day of the year. Office. Mme Felix is a really nasty woman. She says the nastiest things about Denise - why? Kort is charming. "The Joyful Delaneys" (Hugh Walpole) "The Film of Memory" (Shane Leslie). Lecture LeBreton. Waited for Dick for a whole hour. This time, that's it. He's getting ditched. He'll say that I get my 30 frs but I really hate having pupils like him - they won't work, plays around during his lesson and turns on the charm when I get cross. Lesson with Poussif. That kid soaks up English like blotting paper. Read until $1.30 \mathrm{am}$.

\section{Wednesday 22 December}

Woke up at $9.10 \mathrm{am}$. Worked. Lesson with Chabert who was very excited by any reference to sex - what's wrong with them all that they have to wriggle around and fidget like little puppies? "Anthologie nègre" (Blaise Cendrars) ${ }^{550}$ "La Bretagne" (Lébillot). Welsh. Bachellery. The little Raude is letting his beard grow along his jaw line. He looks like a satyr.

\section{Thursday 23 December}

Woke up at $10.15 \mathrm{am}$ !! Oh it's awful. It is so cold. I stay in bed reading until midday. Depressed, depressed, so depressed. Should go see about Godfather's books but can hardly drag one foot in front of the other I feel so depressed. Sadness.

${ }^{550}$ Blaise Cendrars, whose real name was Frédéric-Louis Sauser (1887-1961). Read Lee Rourke's Guardian article for more on the life and work of this French writer:

https://www.theguardian.com/books/booksblog/2007/jul/23/thehazyworldofblaisecendr.

Download novel here:

https://archive.org/details/anthologiengre00cenduoft 
I go to take presents for Maggy Desportes' children - what a great girl. She is ingenious when it comes to her kids. She has made a Father Christmas and because she couldn't find any cotton wool she used "Camelia". What ingenuity! She has to keep everyone on very little money. Izou is an absolute angel. Didn't see Katy because she was asleep. Bought a beautiful little elephant for Will B. He is just so adorable (the elephant that is) that I didn't want to give it away. I want to buy myself one after Christmas. But I also want a flower and "Nuit Enchantée de Merlin". 3 things costing $50 \mathrm{fr}$ a piece. Oh dear. I do so need money. Went to see whether there was any butter or sugar. Still absolutely nothing. That makes 15 days without butter or sugar. Fortunately I still have a little bit of oil. Went mad shopping - because I'm depressed. Got some black rust paint for the gas and two thermometers. One for the outside and one for inside. I am absolutely delighted! A thermometer furnishes a room straight away. Outside (at $6 \mathrm{pm}$ ) $0^{\circ}$. Inside $\underline{1}^{\circ}$. This is why on Wednesday a week ago I was freezing to death. Outside it was (so they say) $-8^{\circ}$ to $-10^{\circ}$. Inside, it was $-7^{\circ}$ to $-9^{\circ}$ at the most. I have a stoic side. Indeed, I have become so stoic that I don't find it cold when it is $-4^{\circ}$ !!! Waiting for Poussif to come for his lesson. I put the radiator on for half an hour and it is $9^{\circ}$. Not bad going!!! Maggy gave me a branch of holly. I decorated Mum's photo with it. I am happy about buying two thermometers. I love this little elephant. I forget to say that Marguerite Delplancq came yesterday to insist that I come on Sunday. Gosh!! Saturday - Sunday - Monday!! Maggy asking me for Thursday!! Lesson with Poussif $\left(10^{\circ}\right)$

\section{Friday 24 December}

Went for a shampoo and set - it took 2 hours to get it done. So that was the morning over. Lesson with Capon. But at $2 \mathrm{pm}$ there was an alert and I was in the métro!! The lighting was switched off and the métro train was going some to get into the station but it was no good - stopped just before Barbès. Wanted to get out but it is quite high and rocky gravel. A lot of women were falling around. In the end I jumped - like a flower. It looked worse than it was. It's always like that. Walked through the dark tunnel to the station and then to my lesson. There was a Christmas tree there and they were making a meal for 20 people and she was sewing little moons, stars and comets and hearts etc all sparkling onto a long black velvet bow for her hair. It will look very pretty I think. Went to the BN for Godfather but because of the alert I arrived there at $4 \mathrm{pm}$ and it was closing. Tried to sell his books. The [. . . librarian didn't want to know - two fakes and the romantic one was too damaged. On the quais they asked me in all seriousness if I had my parents' permission (they thought that I was younger than 21). They offered me 20 frs per volume. At this, went home. I ran about a fair bit for Godfather. Poor old fellow. He set huge store by these three old books thinking that they were worth an amazing amount of money this isn't going to improve my popularity with them but I don't care. They will have to manage. Basically they are treating me like a domestic servant. It is up to them to do what is needed to sell. I hope that he is able to sell them, him 
or someone else at not too low a price. I ordered some Cartes de visite from a fairground stall. I probably should have gone to a real printers but it would have taken time when I'll get them from there on Tuesday. I wanted to buy a bunch of violets but at 20 and 40 francs for 3 sprigs I can't. Miserable looking Christmas without flowers. "La Génie Romain" (A Grenier) 551 "Les Grains de la Grenade" (Tharaud). ${ }^{552}$ Outside $3^{\circ}$. Inside $7^{\circ}$. I'm going to become a proper meteorologist. Annoyed. Didn't get mushrooms opposite for Aunt's tomorrow. Never mind. Will take coffee and a litre of wine and that's it. Anyway, I haven't got any money at all. Rochette doesn't look as if she is going to come for her lesson. That's 40 francs less. I was stupid not to say the last time she missed that it'd still count if I wasn't told before. I will tell her this time and insist that I will have to be at midnight mass (which takes place at $5 \mathrm{pm}$ )

Lesson with Rochette. She brought me 2 pencils ( 1 black, 1 red and blue) and a Christmas card, some blotting paper for my table and a pair of stockings!! Very kind. Madeleine Fortan gave me a croissant - I had given her a cigarette. I have been spoiled this year - lots of presents. Got a note from Cécile Péchegut under the door. She annoys me. The crayons are great! There are loads of [...] reds, blues, blacks!! I'm just a big kid! I'll have to darn a pair of stockings for tomorrow and keep my new ones for a something important. The concert on Radio Nationale is quite good. I don't feel sad this Christmas Eve. I hope that Daddy and lovely Mummy are happy over there at home. Read the Christmas service (Midnight Mass)

\section{Saturday 25 December}

C. Mass. Went to Villeparisis where Aunt was all charm etc, etc. She gave me 100 frs for Christmas. Got fed up. Came home early. Went to Dilys's. Sylvia and Eileen Baron were there. Mrs Evans is very ill. She can't move and speaks like a broken record. Dilys gave me a pair of stockings, 3 eggs, $50 \mathrm{~g}$ of butter. Christmas card from her and from Ruth.

\section{Sunday 26 December}

Mass. Lunch. Dinner. Delplanque gave me a handkerchief in a little clog. They do so love their dead daughter Henriette. That is difficult for the poor little Marguerite. One can fight a living person but not a dead one. [ate chips] 9.30-10 alert.

551 Albert Grenier (1878-1961). French theologian.

552 Jérôme Tharaud (1874-1953). French novelist. Member of the Académie française.

http://data.bnf.fr/11926314/jerome_tharaud/ 


\section{Monday 27 December}

Went to Bachellery's. Fine weather. Met Roberta Owens (60 years old) who is a descendent of the great Robert Owens. She was the one who was released from the camp after breaking both her ankles and having her shoulder and her wrist dislocated falling into the ditch (where she remained until the morning) going to the WC during the night when she wasn't allowed to. She's a giant of a woman, very nice what's more but so snobbish (phew!! 553 ) If she had known that I was a cook's daughter I am sure that she would not have found me as nice. Little William is adorable. He's a fat baby, a little pudgy but friendly. His father only speaks Welsh to him and his mother only French!! If it was the opposite it would be worse! But what is he going to learn and with what accent!! A day at the Bachellerys' is awful. All she talks about is William and school and Gisèle (the maid). He only speaks Welsh and about getting revenge. Fortunately Roberta took the brunt of it. I got back feeling sick and dropped by at Dilys's to return the books that she had lent to Bachellery.

\section{Tuesday 28 December}

Ill all night. Bloating, bloating. At 7 am I took down some peppermint oil. Why didn't I do that before? Mad F did a big clean. I'll shake the rugs, and I'll whistle along to it and I'll have the radio blaring out and bang goes the door, slam goes the door! I could have screamed, the slightest thing got on my nerves. Tried to get up for Chabert's lesson. Impossible. Couldn't for Dick either. Pneu from Poussif who couldn't come because of babysitting. Mad F was kind enough to drop by to ask me whether I needed anything. Got up. Lesson with Rochette. Letter from Jourdain asking for a lesson.

\section{Wednesday 29 December}

9-11 Lesson Delplancq. Shops. 1.30-3 pm lesson with Chabert. Went to get Cartes de Visite. Not very happy. Thought that it would be the others. Chatted with Mad. F. Lesson with Poussif.

\section{Thursday 30 December}

Terrible insomnia. It has been impossible to sleep since 4 am (hungry. In 2 days I think that I have eaten 4 apples, 2 carrots, 3 little eggs like pigeon eggs, 100 gr of noodles) listened to German music which is the only music on at $5 \mathrm{am}$. Housework, scrubbed the floorboards with wire wool. Moved books and food from round the radiator because we have heating today!! Very nice. Lovely sun.

553 'phew' written in English in the manuscript. 
11.30-1 pm alert. Lesson with Chabert. 1.30-2.10 alert. Got paid at the office. Saw Denise. "The Wind Blows West" (B.M. Bower) ${ }^{554}$, "The Life of Katherine Mansfield” (Mantz and Murray). Went to Maggy's for tea. Izou is beautiful. Kitty looks like a little urchin. "She's got the complexion of one of those children painted by Rembrandt" said Maggy. If she was plumper that would be accurate. She snuggled down against me and didn't want to go. Maggy had made a beautiful chocolate log. Met Mlle George there. Maggy gave me a handkerchief. Lesson with Rochette.

\section{Friday 31 December}

Yesterday I was woken up at $4 \mathrm{am}$, this morning, I woke up bright as a button at $10 \mathrm{am}$ !! It is lovely and warm. $11.10-12.50$ and $12.51-1.20$ pm alert. Saw squadron. Lots in the sky but too high and the sky was too blue to see well. The suburbs were bombed. Lesson Capon. Bought a key to bleed the radiator. Now, I don't have to ask the concierge. My tulips and my crocus are coming through as well as the hyacinth!! They are too early. Very moving seeing the first green sproutings. Bought calendar. I don't like it. Too long. Ended the evening and the year doing my bookkeeping. Happiness spoilt a little by having to sleep over at Villeparisis tomorrow. If I had the courage I would find an excuse. I am so bored at their place. On the whole not a bad year. ${ }^{555}$

${ }^{554}$ Bertha Muzzy Sinclair (1871-1940) an American writer specialising in narratives of the American West. She was known under the pseudonym of B.

M. Bower. https://www.fantasticfiction.com/b/b-m-bower/

555 'On the whole not a bad year' written in English in the manuscript. 